\title{
Ecological effects of and recovery following surface mining and pasture reclamation
}

\author{
Michael Levy \\ West Virginia University
}

Follow this and additional works at: https://researchrepository.wvu.edu/etd

\section{Recommended Citation}

Levy, Michael, "Ecological effects of and recovery following surface mining and pasture reclamation" (2012). Graduate Theses, Dissertations, and Problem Reports. 3362.

https://researchrepository.wvu.edu/etd/3362

This Thesis is protected by copyright and/or related rights. It has been brought to you by the The Research Repository @ WVU with permission from the rights-holder(s). You are free to use this Thesis in any way that is permitted by the copyright and related rights legislation that applies to your use. For other uses you must obtain permission from the rights-holder(s) directly, unless additional rights are indicated by a Creative Commons license in the record and/ or on the work itself. This Thesis has been accepted for inclusion in WVU Graduate Theses, Dissertations, and Problem Reports collection by an authorized administrator of The Research Repository @ WVU. For more information, please contact researchrepository@mail.wvu.edu. 


\title{
Ecological effects of and recovery following surface mining and pasture reclamation
}

\author{
Michael Levy \\ Thesis submitted to the \\ Eberly College of Arts and Sciences \\ at West Virginia University \\ in partial fulfillment of the requirements \\ for the degree of \\ Master of Science \\ in \\ Biology \\ Dr. Jonathan Cumming, Ph.D., Chair \\ Dr. Richard Thomas, Ph.D. \\ Dr. Jeffery Skousen, Ph.D. \\ Department of Biology \\ Morgantown, West Virginia \\ 2012
}

Keywords: Surface mining; Reclamation; Arbuscular mycorrhizal fungi; Invasive species 


\section{ABSTRACT \\ Ecological effects of and recovery following surface mining and pasture reclamation \\ Michael Levy}

Surface mining with concurrent reclamation to pasture is a major driver of land use and cover change in Appalachia and constitutes a massive disturbance. Prior research suggests that some aspects of recovery are either slow or incomplete. We examined ecosystem structureincluding soil physical and chemical properties, arbuscular mycorrhizal fungal (AMF) infectivity and community, and plant diversity and community composition-on a chronosequence of pasture-reclaimed surface mines and an unmined pasture in northern West Virginia. We also examined the effect of inoculating red clover, grown with high or low phosphorus, with AMF communities from old and young pasture-reclaimed surface mines and an unmined hillside. Surface mining and reclamation dramatically altered ecosystem structure. Some aspects of ecosystem structure, including many measures of soil chemistry and infectivity of AMF, returned relatively rapidly to levels found on the unmined reference site. Other aspects of ecosystem structure, notably soil physical properties and AMF and vegetation communities, showed incomplete or no recovery over the short-to-medium term. Clover inoculated with AMF from either the young or old mine site were smaller and less phosphorus-efficient than clover inoculated with AMF from the unmined site. Many effects of surface mining and reclamation are not ameliorated in the short-to-medium term. 


\section{Acknowledgements}

I owe debts of gratitude to many people for significant help in bringing this project to completion. I am grateful to West Virginia University and its Biology Department for the spectacular privilege of getting paid to learn, impart knowledge to students, and explore the frontier of knowledge in an area of my choosing. It has been a wonderful experience. My advisor, Dr. Jonathan Cumming, has been outstandingly supportive throughout my tenure, allowing me to pursue my interests, being consistently responsive despite myriad responsibilities, and finding time during evenings and weekends to offer help that many professors wouldn't. I am extremely grateful to have had such an advisor.

My other committee members, Drs. Jeffery Skousen and Richard Thomas, in addition to both teaching classes that shaped my interests, offered valuable suggestions and guidance throughout the thesis process. Dr. Bill Peterjohn was an invaluable informal mentor, and I am grateful to him for numerous lengthy conversations ranging from the state of society and the environment to how best to do science and how to develop a scientific career. He also made possible the carbon and nitrogen analyses found in this project. Dr. Donna Ford-Werntz taught me to see a plant and how to identify the flora of West Virginia, and I thank her for that as well as generous use of the WVU herbarium and helping me identify plants. Zach Fowler, ever knowledgeable about all things West Virginia, also helped with plant identification and was as pleasant an officemate as any graduate student could be. Dr. Joe Morton of INVAM-fame offered invaluable assistance identifying arbuscular mycorrhizal fungal spores, and Dr. Louis McDonald helped with phosphorus analyses; I thank them both.

Ernie Smith showed me the ropes of the lab when I was starting out, could be counted on to help when an extra pair of hands was needed, and had the rare and extremely valuable gift of being able to get tempermental instruments to cooperate. Kylen Whipp, in addition to completing his honors thesis project, helped quantify root colonization, and I am proud that he will be matriculating at WVU Medical School on an Air Force Scholarship in the fall. Thank you to Carol McCarthy, Pat Lutsie, Wendy Sites, Mickey Howell, Diana Hammack, and Judy Fiber for keeping the wheels of research greased. I am grateful to my fellow students for being pleasant companions on the tortuous road that is graduate school.

Finally, I thank my family and partner, Anne, for unwavering belief in me and tolerance for what must have seemed to be interminable conversations about mining, fungi, and the frontier of knowledge. 


\section{Dedication}

For the mighty forests of Appalachia.

May they be allowed to return in all their glory, and soon. 


\section{Table of Contents}

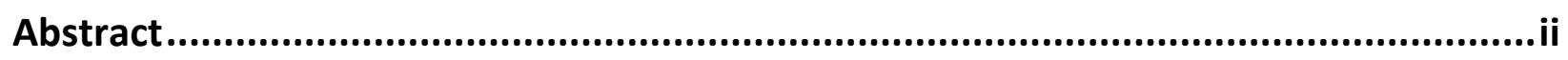

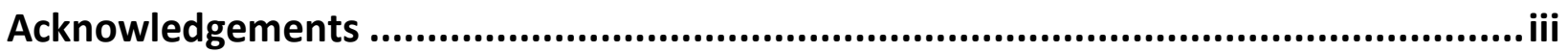

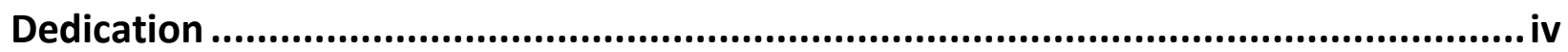

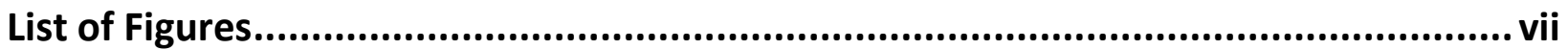

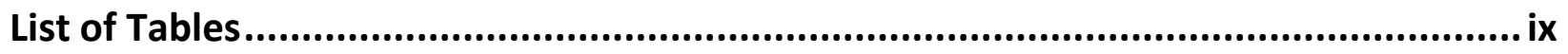

1 Background and hypotheses .............................................................................

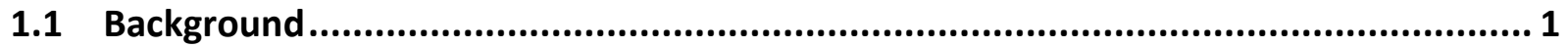

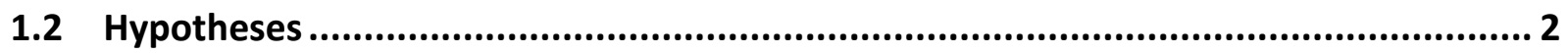

2 A chronosequence investigation of the development of ecosystem structure after surface mining with concurrent reclamation to pasture ......................................6

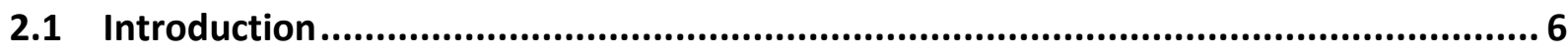

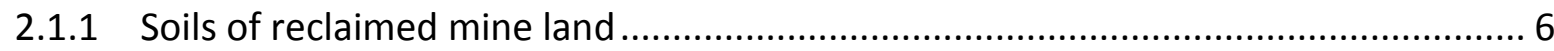

2.1.2 Arbuscuar mycorrhizae of reclaimed minesites .................................................... 7

2.1.3 Vegetation of reclaimed minesites ...................................................................... 9

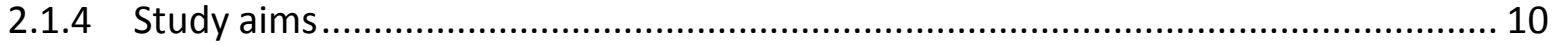

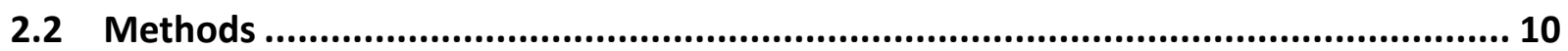

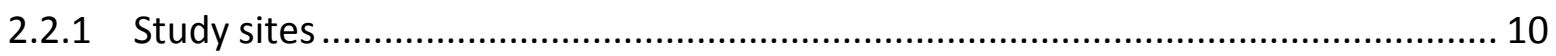

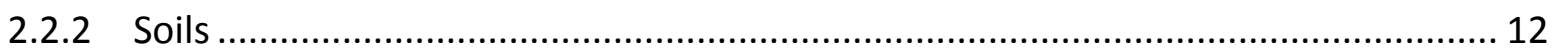

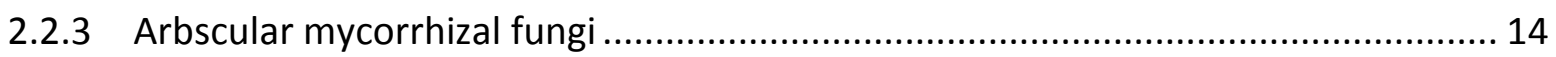

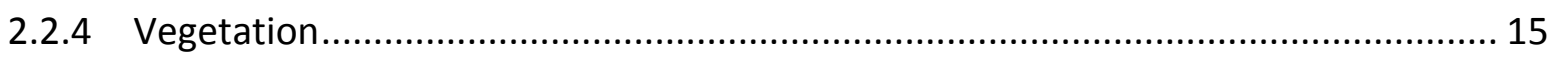

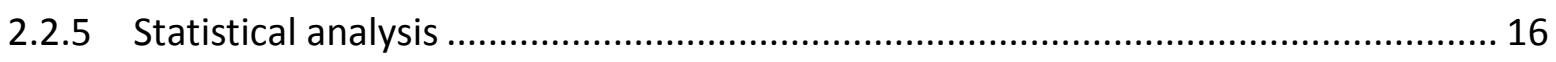

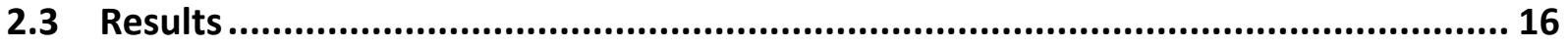

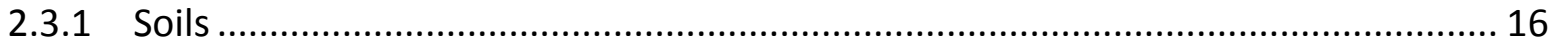

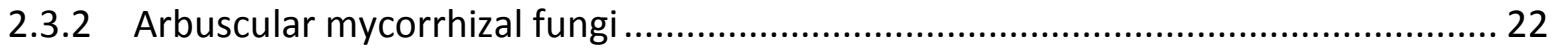

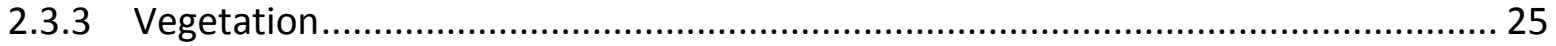

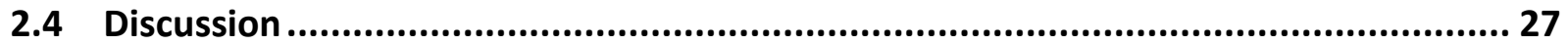

3 Phosphorus stress response of red clover inoculated with arbuscular mycorrhizal fungal communities from reclaimed surface mines..............................................33

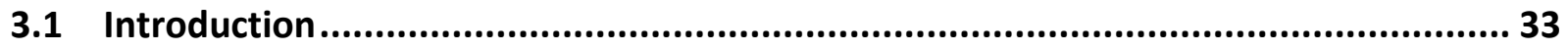




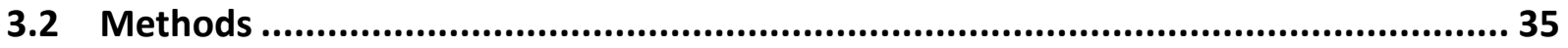

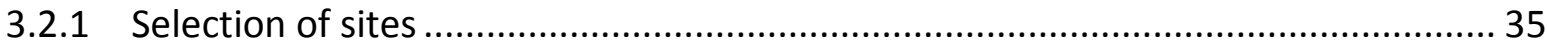

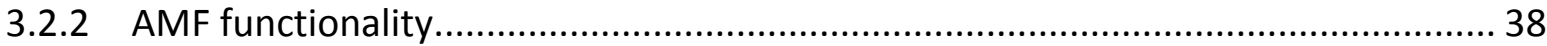

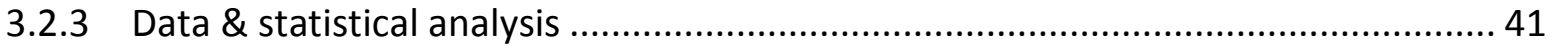

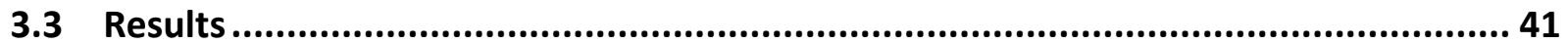

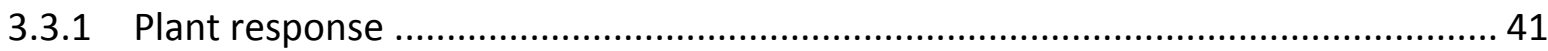

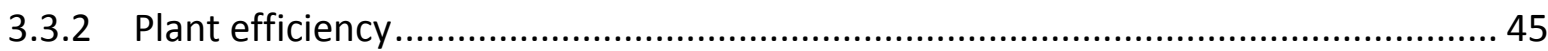

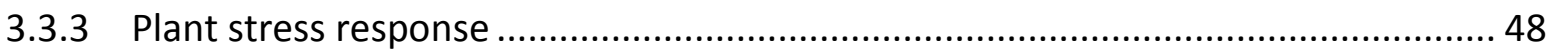

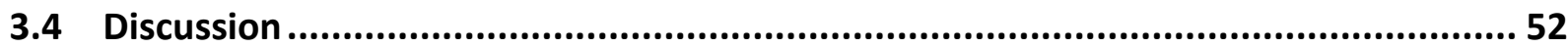

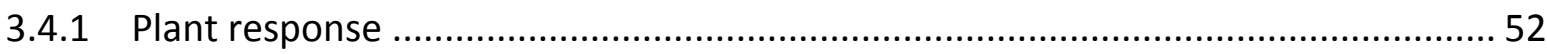

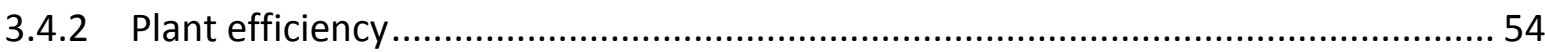

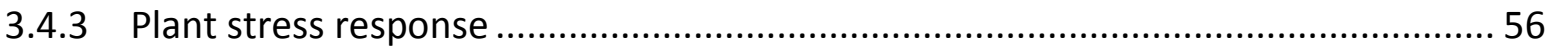

4 Evaluation of hypotheses and conclusions .....................................................58

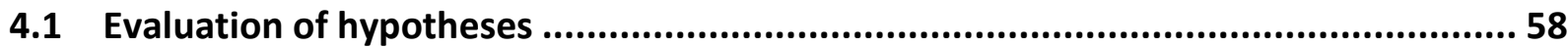

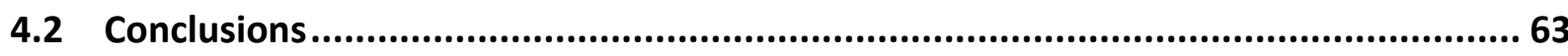

Appendix A. Plant communities of reclaimed mines of various ages......................65

Appendix B. Soils of pasture reclaimed surface mines and unmined pastures near

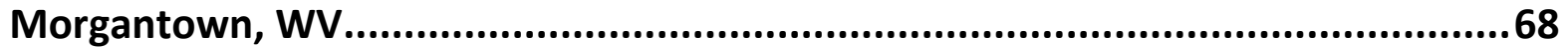

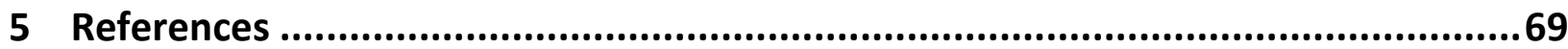




\section{List of Figures}

Figure 2.1. Satellite image of sites used in this chronosequence study. 12

Figure 2.2. Bulk density of soils of reclaimed surface mines of various ages 17

Figure 2.3. Water holding capacity of soils of reclaimed surface mines of various ages. 18

Figure 2.4. Soil pH of reclaimed surface mines of various ages..... 18

Figure 2.5. Soil carbon (a) and nitrogen (b) of reclaimed surface mines of various ages ........... 20

Figure 2.6. Mycorrhizal inoculum potential of reclaimed surface mines of various ages 23

Figure 2.7. Average number of $A M F$ species recovered from trap cultures from reclaimed surface mines of various ages. 23

Figure 2.8. Plant species accumulation curves for reclaimed surface mines of various ages ..... 25

Figure 2.9. Number of plant species present on reclaimed surface mines of various ages ........ 26

Figure 2.10. Shannon Index of Diversity: Plant species richness and evenness on reclaimed surface mines of various ages 26

Figure 2.11. Plant community composition by invasiveness on reclaimed surface mines of various ages

Figure 3.1. Satellite image of sites used in this study.

Figure 3.2. Shoot (a) and root (b) dry mass of red clover.

Figure 3.3. Extent of colonization by AMF of red clover 44

Figure 3.4. Biomass vs. colonization of roots by AMF. 44

Figure 3.5. Leaf tissue $\mathrm{P}$ concentration of red clover 46

Figure 3.6. Biomass vs. tissue $P$. 46 
Figure 3.7. Chlorophyll content of red clover plants.

Figure 3.8. Phosphorus content of leachate from pots..................................................... 48

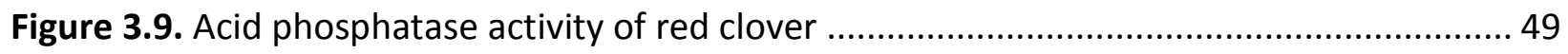

Figure 3.10. Acid phosphatase activity vs. leaf-tissue $\mathrm{P}$ by fungal inoculum ............................ 50

Figure 3.11. Exudation of citrate (a), malate and malonate (b), and lactate (c) ...................... 51 


\section{List of Tables}

Table 2.1. Extractable cations of soils of reclaimed surface mines of various ages

Table 2.2. Inorganic and organic $P$ in sequential extractions from soils of reclaimed surface

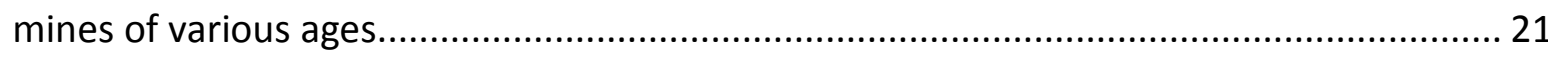

Table 2.3. Communities of arbuscular mycorrhizal fungi recovered from trap cultures from reclaimed surface mines of various ages................................................................ 24

Table 3.1. Communities of arbuscular mycorrhizal fungi recovered from trap cultures from a five year-old reclaimed surface mine, an 18 year-old reclaimed surface mine, and an

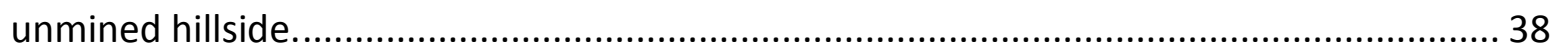

Table 3.2. Phosphorus use index of red clover. 47 


\section{Background and hypotheses}

\subsection{Background}

Due to the magnitude and pervasiveness of changes humans and their industries manifest on Earth's biophysical systems, the present epoch has been termed the Anthropocene (Crutzen and Stoermer 2000). Major features of the Anthropocene include species extinction and invasion, nitrogen deposition, atmospheric carbon accumulation, alteration of hydrological cycles, and land transformation (Steffen and others 2007; Vitousek and others 1997). According to Vitousek and others (1997), "The use of land to yield goods and services represents the most substantial human alteration of the Earth system." Surface mining is likely the most profound land transformation accomplished by humans, making it arguably the apex of the massive impact wrought by humans on the biophysical systems that support life. In spite of this, many important aspects of ecosystem structure and function on surface-mined land remain poorly understood.

As in many other regions, land transformation in Central Appalachia is driven predominantly by coal mining (Brown and others 2005). Since the development of large earthmoving machinery in the mid-twentieth century, surface mining has been increasingly employed in the extraction of coal (U.S. Energy Information Administration 2010). In 2007, 1,326 km² were under permit for surface mining in West Virginia (Office of Surface Mining 2008). However, active surface mines are transient and make up a relatively small area. In contrast, reclaimed mine land is cumulative and makes up a substantial area within Appalachia. For example, Townsend and others (2009) analyzed eight watersheds in the Pennsylvania-West Virginia-Maryland region and found that $5.3 \%$ of the total area, and $15.4 \%$ of the most extensively mined watershed, had been converted to reclaimed mine land.

Since the implementation of the Surface Mining Control and Reclamation Act of 1977 (SMCRA), most surface mined land in Appalachia has been reclaimed at the time of mining to pasture or wildlife habitat (Plass 1982; Plass 2000). Prior to mining, vegetation is cleared, and topsoil is scraped off the site and stockpiled. Geological strata above the coal are blasted, removed, and, 
after coal is extracted, reapplied to approximate original contour. In some instances, layer of coal ash is applied on top of the regraded overburden, and then the homogenized topsoil is respread and compacted by multiple passes with heavy machinery. Finally, a mixture of NPK fertilizer, lime, seeds of grasses and forbs, and a binding agent are sprayed onto the soil. This collective process may be referred to as pasture-reclamation (PR).

The practices of compacting soil and seeding aggressive groundcover have proven effective for improving slope stability, controlling erosion, and improving the aesthetics of sites (Bell and others 1989), all major goals of SMCRA. By rapidly establishing a continuous groundcover, PR generally allows the return of mine operators' bonds within a period of five years (McElfish and Daniels 1990). However, after only five years, the physical properties, biogeochemistries, and plant communities have developed little from the time of reclamation.

The goal of these studies was to elucidate the ecological development over the short-medium term of surface mines reclaimed to pasture. Special attention was paid to the arbuscular mycorrhizal fungi, as these often-ignored microorganisms are important determinants of ecosystem structure and function but could be damaged during mining and reclamation. Hopefully this work can help those who shape reclamation practices ensure that the unique landscapes generated by surface mining and reclamation have as positive an impact as possible on the greater ecosystem functioning that supports all life and society.

\subsection{Hypotheses}

Study 1 - A chronosequence of surface mines reclaimed to pasture $0,3,7$, and 12 years ago and an unmined reference pasture were examined for soil properties, arbuscular mycorrhizal fungal infectivity and community, and plant community diversity and composition.

\section{1) Soils}

A) Physical soil properties

i) Soils will be severely compacted after mining, and little recovery of bulk density will be observed over twelve years. 
ii) Water holding capacity will be severely reduced on recently reclaimed mines and will recover modestly over twelve years.

B) Chemical soil properties

i) Soil $\mathrm{pH}$ will be elevated immediately after reclamation and will return to natural, acidic levels by 12 years after reclamation.

ii) Soil $\mathrm{C}$ will be massively reduced on the youngest reclaimed mines and will accumulate over time.

iii) Soil $\mathrm{N}$ will be high immediately after reclamation and will then decline over the first few years before accumulating thereafter.

iv) Inorganic phosphorus will be very high immediately after reclamation and will decline over time.

v) Organic phosphorus will follow an inverse pattern to inorganic $P$, being much reduced on the youngest mines and accumulating over time.

2) Arbuscular mycorrhizal fungi

A) AMF inoculum potential will be drastically reduced on the young reclaimed sites and will recover over twelve years to approximately the same level as the unmined reference site.

B) AMF community

i) The community of AMF will be less diverse in the immediate aftermath of reclamation.

ii) The AMF community will become more diverse over a twelve year period but will not reach the diversity of the unmined reference site and much of this diversity gained over time will come from species not found on the unmined site.

3) Vegetation

A) Plant species diversity will be very low immediately following reclamation and will increase over time.

B) However, the plant community on even the oldest PR sites will be significantly less diverse than the unmined reference site. 
C) A greater fraction of the plant community on all reclaimed mine sites will be made up of non-native species than the unmined site.

Study 2 - Communities of arbuscular mycorrhizal fungi from an 18 year-old pasture-reclaimed surface mine (old mine), a five year-old pasture-reclaimed surface mine (young mine), and an unmined hillside (unmined site) were tested on red clover for their ability to confer benefits to their plant hosts under high and low phosphorus conditions.

1) Plant response

A) Plant biomass

i) Red clover inoculated with AMF from the unmined site will be the largest and this difference will be pronounced for plants that receive $100 \mu \mathrm{M}$ P.

ii) Red clover inoculated with fungi from the young mine will be the smallest independent of $\mathrm{P}$ treatment.

B) Colonization

i) Red clover inoculated with fungi from the young mine will be the least colonized, and plants inoculated with fungi from the unmined site will be the most colonized.

ii) There will be a direct relationship between colonization and plant biomass, and this relationship will be stronger for plants given $10 \mu \mathrm{M} \mathrm{P}$.

2) Plant efficiency

A) Leaf tissue $P$

i) Tissue $\mathrm{P}$ will be most concentrated in red clover plants inoculated with fungi from the young mine and least concentrated in plant inoculated with fungi from the unmined site.

ii) There will be an inverse relationship between tissue $P$ and biomass, and this effect will be pronounced in plants given $10 \mu \mathrm{M}$ P.

iii) Phosphorus use index will be greatest for red clover plants inoculated with AMF from the unmined site and least for plants inoculated with AMF from the young mine. 
B) Leaf chlorophyll

i) Leaf chlorophyll will be greater in red clover given $100 \mu \mathrm{M}$ P than those given $10 \mu \mathrm{M}$ P.

ii) Leaf chlorophyll will be greatest in red clover inoculated with AMF from the unmined site and least in plants inoculated with AMF from the young site.

C) Leachate $P$ will be most concentrated from pots containing inoculum from the young mine and least concentrated from pots containing inoculum from the unmined site.

3) Plant stress response

A) Acid phosphatase activity

i) Acid phosphatase activity will be greatest in clover plants inoculated with AMF from the young mine and least in plants inoculated with AMF from the unmined site, and this effect will be exasperated among plants given $10 \mu \mathrm{M}$ P.

ii) Acid phosphatase activity will exhibit an inverse relationship to plant tissue $P$ concentration, and this effect will be most pronounced in plants inoculated with fungi from the unmined site.

B) Organic acid production will be greatest among red clover plants with AMF from the young mine and least in plants inoculated with AMF from the unmined site, and this effect will be exasperated among plants given $10 \mu \mathrm{M}$ P. 


\section{A chronosequence investigation of the development of ecosystem structure after surface mining with concurrent reclamation to pasture}

\subsection{Introduction}

\subsubsection{Soils of reclaimed mine land}

The chemical, physical, and microbial properties of soil are altered during topsoil stripping, stockpiling, and respreading associated with mining and pasture reclamation (Indorante and others 1981; Harris and others 1989; Simmons and others 2008). Soil is generally extensively compacted with heavy machinery in order to produce a homogenous surface that is accessible to farm equipment (Skousen and others 2009), and bulk density of soil is much greater after reclamation (Indorante and others 1981; Simmons and others 2008). This compaction severely limits water infiltration (Haering and others 2004), and, as a result, plant root growth, mycorrhizae formation, phosphorus acquisition, and, ultimately, shoot growth (Brenner and others 1984; Nadian and others 1997; Yano and others 1998). These limitations will limit soil development and ecosystem recovery.

The removal of all vegetation from a site prior to mining constitutes a massive loss of $\mathrm{C}, \mathrm{N}$, and other nutrients from the ecosystem. In a comprehensive paired comparison of a forested watershed and a pasture reclaimed (PR) watershed 15 years after reclamation in Virginia, Simmons and others (2008) found soil C and N levels in the PR watershed were less than half of levels in the forested watershed in both the $\mathrm{O}$ and $\mathrm{A}$ horizons. Soil $\mathrm{P}$ levels in PR watershed were 6.7 and 3.3 times less than in the forested watershed in the $\mathrm{O}$ and $\mathrm{A}$ horizons, respectively. Roberts and others (1988) also found decreased available $\mathrm{P}$ after mining and reclamation.

The topsoil stockpiling process homogenizes soil horizons, compromises soil structure and decreases microbial biomass, diversity, and activity (Harris and others 1989), reduces earthworm populations (Scullion and others 1988), and reduces mycorrhizal infection potential 
(Abdul-Kareem and McRae 1984; Gould and Liberta 1981). Pasture reclamation decreases the concentration of saprophytic fungi and alters their species composition (Simmons and others 2008; Zak 1992); however, some taxa have been shown to return to pre-disturbance levels within four years of reclamation (Fresquez and others 1986), likely as a consequence of tolerance to stressful conditions encountered during mining and reclamation such as low soil moisture.

\subsubsection{Arbuscuar mycorrhizae of reclaimed minesites}

Arbuscular mycorrhizal fungi (AMF) are obligate plant symbionts that form associations with the roots of more than $80 \%$ of vascular land plants (Schussler and others 2001). In exchange for carbon from plants, AMF scavenge nutrients, especially $P$, and water from soils for their plant hosts (Augé 2001; Smith and Read 2008). In addition to increasing nutrient and water uptake, AMF provide plants with protection from metal toxicity (Arriagada and others 2007; Cumming and Ning 2003; Dueck and others 1986) and microbial attack (Pozo and Azcón-Aguilar 2007; Whipps 2004). Local adaptation has been demonstrated for AMF-conferred resistance to metal stress (Gildon and Tinker 1983; Leyval and others 1995), such that plants grown in heavy-metal contaminated soil fare better when associated with an AMF ecotype that has previously been exposed to that heavy metal than a naive ecotype of the same fungus. Additionally, Johnson and others (2010) found that plants and AMF coadapt to local conditions to maximize mutualism, nutrient uptake, and carbon capture on nutrient limited sites.

AMF play an important role in determining vegetation community composition and productivity. By manipulating AMF species richness in experimental macrocosms designed to simulate North American old field conditions, van der Heijden and others (1998) showed that increased AMF species richness causes increased plant diversity, nutrient uptake, and productivity. Grime and others (1987) also found increased plant diversity with increased AMF diversity. In contrast, Hartnett and Wilson (1999) used a fungicide to suppress mycorrhizal activity in tallgrass prairie plots in Kansas and found a large increase in plant species richness

and no change in plant biomass. Species interactions flow in the opposite direction as well: changes in vegetation composition affect AMF diversity, whether the changes in plant 
community are experimentally manipulated (Johnson and others 2004) or naturally occurring (Cumming and Kelly 2007).

Given the presence on PR sites of potentially phytotoxic metals from the application of coal ash, low rates of water infiltration, and low levels of important nutrients, AMF may be critical for the long-term success of reclamation. However, the stockpiling process reduces mycorrhizal infectivity (Abdul-Kareem and McRae 1984; Gould and Liberta 1981); the application of NPK fertilizer reduces AMF root colonization and hyphal length (Gryndler and others 2006); and heavy metals decrease AMF infectivity, spore count, and spore germination (Leyval and others 1995). In addition to altering levels of AMF, these stresses, together with the seeding of a foreign vegetative community, may affect community composition of AMF, which could potentially exclude recolonization by native plants or lead to the decline of sites.

AMF on reclaimed mines have been studied in Wyoming (Allen and Allen 1980), Europe (Püschel and others 2008), and India (Mehrotra 1998); however, a literature search revealed no published studies of AMF on reclaimed mines in the Appalachian coal region. In the arid Powder River Basin of Wyoming, Allen and Allen (1980) found that AMF spore counts and infection levels recovered over a three year period following reclamation to approximately $50 \%$ of levels found on an adjacent, undisturbed site. Most of the colonizing annuals on the reclaimed site were nonmycorrhizal. Stahl and others (1988), also in the Powder River Basin, planted on a reclaimed mine Wyoming big sagebrush inoculated with AMF from an adjacent, undisturbed site and found little colonization or effect on growth. Fourteen years later, Frost and others (2001) reexamined the Stahl and others (1988) site and found little overlap between the five AMF species found on the undisturbed site and the four AMF species found on the reclaimed site and severely depressed spore counts on the reclaimed site. Püschel and others (2008), in the Czech Republic, found rapid reestablishment of AMF, but also demonstrated that the early establishment of nonmycorrhizal plants decreased AMF infectivity and concluded that the mycorrhizal status of early establishing plant species may affect succession among the plant community. 


\subsubsection{Vegetation of reclaimed minesites}

Reclamation regulations put in place by SMCRA promote the planting of very fast growing groundcover species on PR sites that can slow or stall natural succession (Skousen and others 2006; Torbert and others 2000). Exotic invasive plants like Kentucky 31 tall fescue (Festuca arundinacea var. KY 31) and Sericea lespedeza (Lespedeza cuneata) are often seeded in reclamation (Zipper and others 2011). The return of native species may be limited by direct competition and, potentially, through feedback loops with mycorrhizal fungi, as in Bever (2002) and Zhang and others (2010).

Because modern reclamation practices have only been in place for several decades, and because reclamation laws and priorities have changed over time, confounding site age and reclamation technique, it has been difficult to map the successional trajectory of PR mine sites. Furthermore, there are many factors that affect successional trajectory, and they interact in complex, often threshold-dependent ways (Suding and others 2004). However, old fields offer another example on which reestablishment of vegetation from pre-disturbance propagules is limited. The plant species present at the termination of management of old fields has a dramatic effect on their successional trajectory (Myster 1993). Similarly, the presence of thick cover of grasses in abandoned tropical pasture slows recolonization by early-successional woody species. Thus, the species planted on minesites-which form the community into which recolonizing plants must penetrate-may have important consequences for the development of ecosystems on these sites.

Central Appalachia was almost entirely forested prior to European arrival (Watts 1979), but trees struggle to invade the thick ground cover and compacted soil of PR sites (Ashby 1998; Chaney and others 1995; Skousen and others 2009). Holl (2002) examined the vegetation on PR sites in southwestern Virginia and found that many native species, including some trees, had returned. However, even after 35 years, many native trees and herbaceous species were not found in any of the reclaimed sites. Furthermore, all but the most recently reclaimed sites surveyed by Holl (2002) were reclaimed pre-SMCRA, and reclamation practices among age 
classes of sites varied significantly, including whether or not topsoil was replaced and whether or not trees were planted.

\subsubsection{Study aims}

To elucidate the development of PR minesites in Appalachia and highlight potential barriers to return of native-type ecosystems, we examined soil physical and chemical properties, AMF infectivity and community, and vegetation diversity and community composition on four surface mines reclaimed between zero and 12 years prior and an unmined, managed pasture as a reference site in northern West Virginia. We hypothesized that, in general, older reclaimed mines would be more similar to the unmined reference site than younger reclaimed mines.

\subsection{Methods}

\subsubsection{Study sites}

A chronosequence of surface mines reclaimed to pasture at the time of mining was developed. All sites were within a $5 \mathrm{~km}$ radius approximately $10 \mathrm{~km}$ west of Morgantown, West Virginia (Figure 2.1). All of the mine sites were operated and reclaimed by Patriot Mining Company. Reclamation was completed in 1998 for the oldest site (R12), 2003 (R7), 2007 (R3) and May, 2010 (R0). Dates of termination of mining were confirmed by satellite imagery using Google Earth. The unmined pasture reference site (Pasture) has been in pasture since at least 1993. All sites were mined for the Waynesburg coal seam (Pennsylvanian Period, Monongahela Group) and reclaimed using similar techniques.

After coal was removed, overburden was returned to the approximate original contour of the site. A $\sim 15 \mathrm{~cm}$ layer of fluidized bed combustion (FBC) fly ash from the Morgantown Energy Associates Power Plant was applied to the top of the regraded overburden, as is standard practice in this region. The ash was approximately $20 \% \mathrm{CaO}$ and had a pH of 11 (Skousen and others 2009). The ash forms a weak cement when wetted which improves slope stability and reduces water infiltration into overburden which may contain acid mine drainage creating minerals. On top of the fly ash, topsoil that had been stockpiled during mining was respread 
and compacted by bulldozers. Exact details of fertilization, liming, and species seeded were not available; however, typical reclamation of surface mines in this region consists of liming, heavy fertilization with NPK fertilizer, and seeding at high rate of pasture grasses and legumes such as Festuca arundinacea, Dactylis glomerata, Lotus corniculata, and Trifolium pratense. The R0, R3, and R7 sites appeared to have been unmanaged since completion of reclamation. The Pasture and R12 sites crossed property boundaries and, as such, management varied within these sites. Some areas within them were cut for hay 1-2 times per year and some were periodically limed and NPK fertilized while others were not. This heterogeneity of management is typical of pasture-reclaimed mine land in the region.

Three plots were delineated within each site. Where possible, a variety of aspects were selected among plots within a site. Due to spatial limitation, plots on the R0 site were $25 \times 10 \mathrm{~m}$ and were separated by $10 \mathrm{~m}$; for all other sites, plots were $50 \times 20 \mathrm{~m}$, with the long axes of plots perpendicular to contour of the hill. At least a $10 \mathrm{~m}$ buffer from roads and forests was maintained for all plots except on the R0 site, where the plots were $\sim 5 \mathrm{~m}$ downhill from a dirt road used by mine equipment. Excluding the RO site, mean distance between plot centers ranged from 142 to $345 \mathrm{~m}$. 


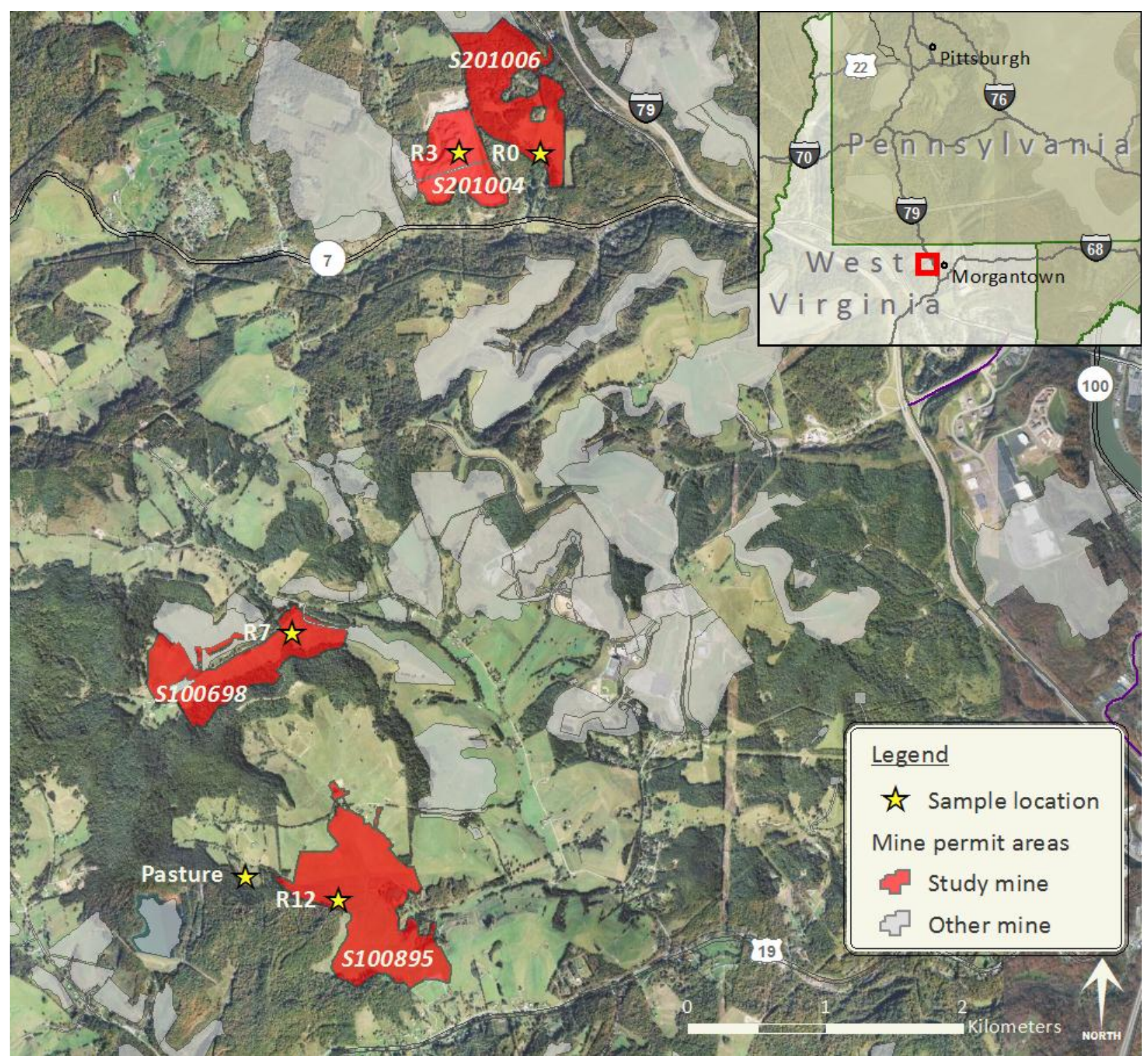

Figure 2.1. Satellite image of sites used in this chronosequence study. Shaded areas are those permitted for surface mining by the West Virginia Department of Environmental Protection (WVDEP) since 1977. Red areas are the mines studied herein, and italicized numbers are WVDEP permit numbers for those mines. $\mathrm{RO}$ is a surface mine reclaimed zero years ago, etc., and Pasture is an unmined pasture.

\subsubsection{Soils}

To analyze water holding capacity and bulk density of soils, coordinates for three locations in each plot were produced by a random number generator, with the condition that exactly one location be within each third of each axis. To determine bulk density, a core of soil $10 \mathrm{~cm}$ deep with $7.5 \mathrm{~cm}$ diameter was carefully extracted using a bulb planter. The mass of the soil was determined after drying to constant mass at $110^{\circ} \mathrm{C}$, and the volume of the soil was determined 
by filling the extracted soil's hole with a measured volume of sand. Because this method produces lower values than other methods, a correction factor was applied based on the ratio of bulk density obtained using this method versus careful excavating a $10 \times 10 \times 10 \mathrm{~cm}$ block of soil and similarly measuring volume and dry mass. Water holding capacity was determined by similarly extracting a core of soil and, keeping the structure of the core as intact as possible, transferring the soil to a metal cylinder $11 \mathrm{~cm}$ tall with $7.5 \mathrm{~cm}$ diameter with a bottom of fine mesh screen. The soil was saturated with water, allowed to drain overnight at $4^{\circ} \mathrm{C}$ and weighed. The soil was then dried to constant mass at $110^{\circ} \mathrm{C}$ and weighed again. Water holding capacity was calculated as mass of water held by soil after saturation and draining as a percent of dry soil mass.

From each plot, four soil samples were collected in June of 2010 in a stratified-random manner for chemical analysis. Samples were taken to depth of $10 \mathrm{~cm}$ at 5, 18.3, 31.7, and $45 \mathrm{~m}$ on the long axis of plots, at random locations on the short axis. Samples within a plot were combined in a plastic 5 gallon bucket, stored a $4^{\circ} \mathrm{C}$ for approximately two weeks before being air dried, sieved to pass through a $5.6 \mathrm{~mm}$ mesh, and stored at room temperature until analysis.

Soil $\mathrm{pH}$ was measured in a 1:5 soil:water slurry. Total soil $\mathrm{C}$ and $\mathrm{N}$ were determined by combustion with a Carlo Erba NA 1500 elemental analyzer (Carlo Erba Strumentazione, Milan, Italy). Soil $\mathrm{K}, \mathrm{Ca}, \mathrm{Mg}, \mathrm{Mn}, \mathrm{Zn}, \mathrm{Pb}, \mathrm{Cr}$, and $\mathrm{Cd}$ were determined by Mehlich 3 extraction (Mehlich 1984) and ICP-AES (P400, Perkin Elmer, Norwalk, CT).

Soil $\mathrm{P}$ was fractionated based on lability and speciation. In a $50 \mathrm{ml}$ centrifuge tube, $2 \mathrm{~g}$ soil was shaken at $250 \mathrm{rpm}$ in $20 \mathrm{ml} 0.01 \mathrm{M} \mathrm{CaCl}_{2}$ for $1 \mathrm{~h}$. After a $10 \mathrm{~min}$ centrifugation at 3,000 rpm, the supernatant was decanted, filtered through $45 \mu \mathrm{m}$ quantitative filter paper, and brought to volume ("CaCl 2 fraction"). To the soil, $40 \mathrm{ml} 1 \mathrm{M} \mathrm{NH}_{4} \mathrm{Cl}$ was added, and tubes were shaken at $250 \mathrm{rpm}$ for $30 \mathrm{~min}$, centrifuged, decanted, filtered, and brought to volume (" $\mathrm{NH}_{4} \mathrm{Cl}$ fraction"). Finally, $20 \mathrm{ml}$ of Mehlich 3 solution (Mehlich 1984) was added, tubes were shaken at $180 \mathrm{rpm}$ for $5 \mathrm{~min}$, centrifuged, decanted, filtered, and brought to volume ("Mehlich 3 fraction"). For each fraction, inorganic $P$ was determined by the malachite green method (Ohno and Zibilske 
1991). Total P was determined by ICP-AES (P400, Perkin Elmer, Norwalk, CT) and organic P calculated as the difference between total and inorganic $P$.

\subsubsection{Arbscular mycorrhizal fungi}

To determine the infectivity of AMF, a mycorrhizal inoculum potential (MIP) assay was undertaken (Moorman and Reeves 1979). Fresh inocula were collected as described above on a single day in mid-October, 2010. Seeds of a nitrogen-fixing legume, red clover (Trifolium pretense), a commonly seeded, invasive C3 grass, Kentucky 31 fescue (Festuca arundinacea var. KY 31), or a native C4 grass, little bluestem (Schizachyrium scoparium), were planted in RLC4 Cone-tainers (Stuewe \& Sons, Tangent, OR). Plants were maintained in a growth chamber under mixed fluorescent and incandescent bulbs at $\sim 260 \mu \mathrm{mol} / \mathrm{m}^{2} / \mathrm{sec}$ PAR for $14 / 10 \mathrm{~h}$ day/night cycle of $25 / 20^{\circ} \mathrm{C}$, with humidity $\sim 50 \%$. One week after planting, pots were thinned to two plants each. Thirty days after planting, roots were rinsed free of soil, cleared in $\mathrm{KOH}$ in a $121^{\circ} \mathrm{C}$ autoclave for $15 \mathrm{~min}$, rinsed five times, twice acidified in $2 \% \mathrm{HCl}$ for $10 \mathrm{~min}$, and stained for 30 min with hot $0.05 \%$ trypan blue in 1:1:1 water:glycerol:lactic acid. Stained roots were stored in water at $4^{\circ} \mathrm{C}$ for at least 5 days to allow dye to diffuse from uncolonized tissue. Colonization of roots was quantified by the gridline intersect method (Giovannetti and Mosse 1980).

To elucidate the community of AMF present on each site, AMF were trapped in pot cultures (Morton 1993) to produce spores for identification. Fresh inocula from all sites were collected in a single day in late September, 2010. At three sample locations determined by a random number generator, with the condition that exactly one location be within each third of each axis, soil samples to $10 \mathrm{~cm}$ depth were collected and combined within plot and stored in sealed plastic bags at $4^{\circ} \mathrm{C}$. Vegetation is dense on these sites, so collections included abundant roots. Inocula were prepared by chopping soil and roots to $\sim 2 \mathrm{~cm}$ fragments, mixing soil and roots 1:1 with sand in $15 \mathrm{~cm}$ pots, planting 100 sudangrass (Sorghum bicolor subsp. Drummondii) seeds, and covering with $\sim 5 \mathrm{~mm}$ sand. One trap pot was employed for each of three plots on each site. 
Trap pots were maintained in a greenhouse under $14 \mathrm{~h}, 25^{\circ} \mathrm{C}$ days with supplemental light from metal halide bulbs and $10 \mathrm{~h}, 20^{\circ} \mathrm{C}$ nights. An automated system delivered deionized water in volume sufficient to saturate pots three times a day. Once a week during weeks 6-9, each trap pot received $100 \mathrm{ml}$ of 0.1-strength modified Johnson's nutrient solution (Johnson and others

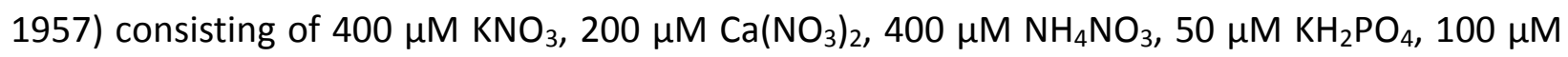
$\mathrm{MgSO}_{4}, 20 \mu \mathrm{M} \mathrm{KCl}, 25 \mu \mathrm{M} \mathrm{H}_{3} \mathrm{BO}_{3}, 2 \mu \mathrm{M} \mathrm{MnSO}_{4}, 2 \mu \mathrm{M} \mathrm{ZnSO}_{4}, 0.5 \mu \mathrm{M} \mathrm{CuSO}_{4}, 0.5 \mu \mathrm{M} \mathrm{Na}{ }_{2} \mathrm{MoO}_{4}$, $0.5 \mu \mathrm{M} \mathrm{CoCl}_{2}$, and $20 \mu \mathrm{M}$ FeNa-EDTA at pH 6.0. After 90 days, watering was stopped and plants were allowed to desiccate in pots for four weeks to reduce $C$ allocation to AMF and induce sporulation (Morton 1993). Pot contents were thoroughly chopped, and two $50 \mathrm{ml}$ samples were taken from each pot and spores recovered via nested sieving and sucrose centrifugation (Cumming and Kelly 2007). For identification, spores were mounted on microscope slides and identified using descriptions and pictures from the International Culture Collection of Arbuscular Mycorrhizal Fungi (INVAM) website (invam.caf.wvu.edu) based on characteristics including size, color, surface texture, spore and germinal wall character, subtending hypha arrangement, and reactivity with Melzer's reagent (Morton 1993). Species morphotypes were recorded as present or absent in each pot.

\subsubsection{Vegetation}

To capture the full plant community present on sites, sampling was done in two stages, a qualitative survey in late-June/early-July and a quantitative survey in late-August/earlySeptember, 2010. For the qualitative survey, a $10 \mathrm{~m}^{2}$ area with a $5 \mathrm{~m}$ axis perpendicular to slope contour was randomly demarked in each plot, and the plant species present therein were identified. For the quantitative survey, at 0,25 , and $50 \mathrm{~m}$ on the long axis of plots, a circular $0.25 \mathrm{~m}^{2}$ quadrat was placed at a random location, and the number of individuals of each species therein was tallied. For grasses, each culm was counted as an individual. Species richness was calculated as the number of species found on a plot in both surveys. Plant diversity was calculated as the Shannon Index (Shannon and Weaver 1949) for each plot based on the number of individuals found in the quantitative survey. 


\subsubsection{Statistical analysis}

Statistical analyses were carried out using SAS-JMP version 8.0 or 9.0 (SAS Institute, Cary, NC). Plots served as replicates within sites for fixed-effect ANOVA, which was used with post-hoc Tukey HSD tests to assess differences among sites. For bulk density and water holding capacity, within plot measurements were averaged and plot averages used as replicates. For MIP, site and host-species were crossed in a full-factorial two-way ANOVA. Likelihood-ratio chi-square tests were used to determine whether AMF species occurrence varied among sites.

\subsection{Results}

\subsubsection{Soils}

Bulk density of soil varied significantly among sites (Figure 2.2; $p<0.001$ ) and was significantly less on the unmined pasture than any of the reclaimed sites (by Tukey HSD $\alpha=0.05$ ). Bulk density was similar on R0, R3, and R7 and on R12 was intermediate between the other reclaimed sites and the unmined site. Water holding capacity varied significantly among sites (Figure 2.3; $p<0.001$ ), with the unmined pasture holding $86 \%$ more water than the average of reclaimed sites, among which WHC did not vary significantly (by Tukey HSD $\alpha=0.05$ ).

Soil $\mathrm{pH}$ was significantly different among sites (Figure 2.4; $\mathrm{p}<0.001$ ), but not among the older reclaimed sites and the unmined pasture (R7, R12, and Pasture not different by Tukey HSD $\alpha=$ 0.05). Relative to the other sites, soil $\mathrm{pH}$ on $\mathrm{R} 3$ was particularly high (7.2), and soil $\mathrm{pH}$ on $\mathrm{RO}$ was particularly low (4.6).

In general, Mehlich 3-extractable nutrient cations and heavy metals varied significantly across sites (Table 2.1); the pattern of variation was different among the various cations. For example, Ca followed a pattern similar to $\mathrm{pH}$, being very low relative to other sites on $\mathrm{RO}$, very high on R3, and similar on the older PR sites and unmined pasture, and soil Mg largely paralleled soil Ca. Soil $\mathrm{K}$ was similar across sites. Notably, none of the heavy metals tested were especially elevated on the PR sites relative to Pasture; in fact, $\mathrm{Pb}$ was elevated on Pasture relative to the PR sites. 
Soil $\mathrm{C}$ and $\mathrm{N}$ were present at very low levels on the most recently reclaimed sites. Levels increased with age and were similar on R7 and R12 to those of the unmined site (Figure 2.5; carbon $p<0.001$; nitrogen $p<0.001)$. The amount of inorganic phosphate recovered in each fraction of a sequential extraction differed significantly among sites (Table 2.2; $\mathrm{CaCl}_{2} \mathrm{p}=0.027$; $\mathrm{NH}_{4} \mathrm{Cl} p=0.007 ;$ Mehlich $3 \mathrm{p}=0.002$ ). Mehlich 3-extractable $\mathrm{P}_{\mathrm{i}}$ was an order-of-magnitude greater on $\mathrm{R} 3$ than any other site. $\mathrm{P}_{\mathrm{i}}$ in the more labile $\mathrm{CaCl}_{2}$ and $\mathrm{NH}_{4} \mathrm{Cl}$ fractions made up a tiny portion of recovered $\mathrm{P}_{\mathrm{i}}$ and were greater on Pasture than the PR sites. The amount of organic phosphorus recovered in each fraction also varied among sites (Table 2.2; $\mathrm{CaCl}_{2} \mathrm{p}<0.001$; $\mathrm{NH}_{4} \mathrm{Cl} p=0.033$; Mehlich $\left.3 \mathrm{p}<0.001\right)$. Across all three fractions, there was a tendency for $\mathrm{P}_{\mathrm{o}}$ to increase with age. Soil $\mathrm{P}_{\mathrm{o}}$ was present in especially low concentration in the $\mathrm{CaCl}_{2}$ and $\mathrm{NH}_{4} \mathrm{Cl}$ fractions on the younger PR sites and recovered to levels similar to Pasture by R12. Total extractable $\mathrm{P}_{\mathrm{o}}$ also tended to increase with age but did not approach levels on Pasture on any of the PR sites.

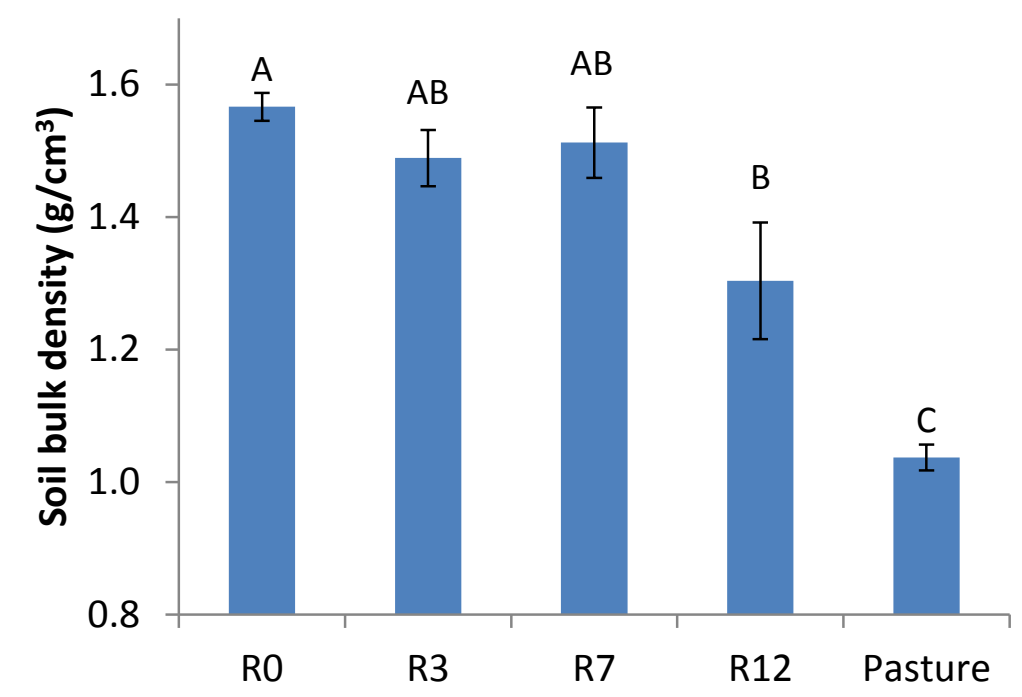

Figure 2.2. Bulk density of soils of reclaimed surface mines of various ages. R0 is a surface mine reclaimed zero years ago, etc., and Pasture is an unmined pasture. On each site, three $1,000 \mathrm{~m}^{2}$ plots were delineated, and averages of three measurements on each plot were used as the statistical unit of analysis. Bulk density was determined by removing a $10 \mathrm{~cm}$ deep core of soil, filling the void with a measured volume of sand, and drying the core to constant weight. Bars that don't share a letter are different by Tukey HSD $\alpha=0.05$. 


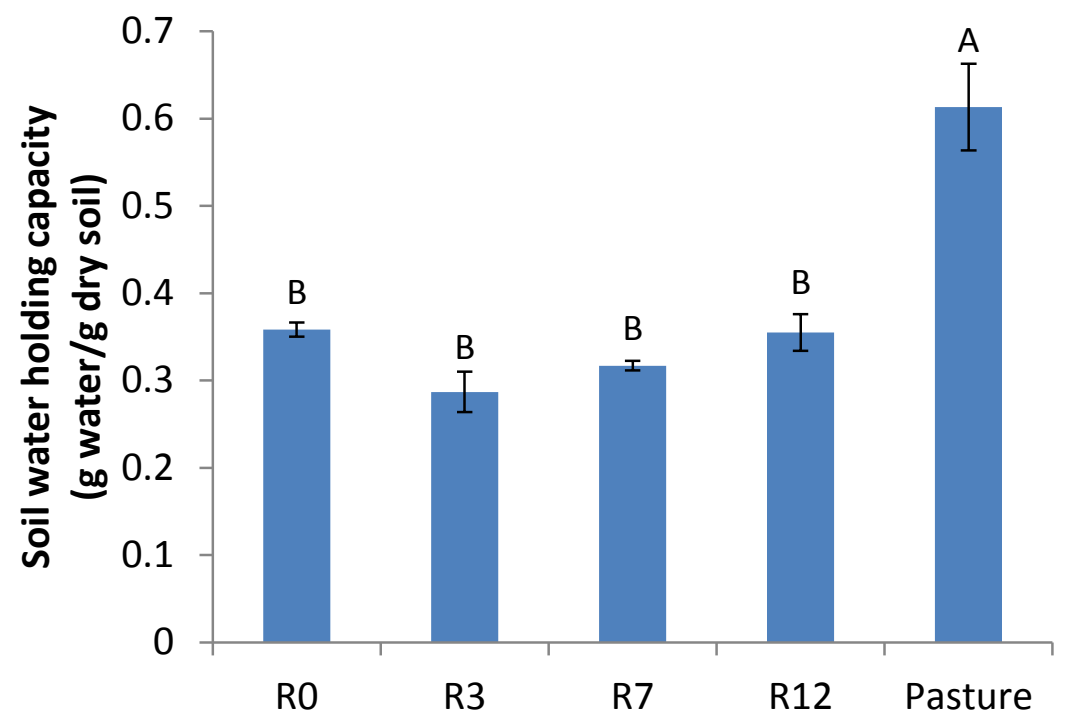

Figure 2.3. Water holding capacity of soils of reclaimed surface mines of various ages. R0 is a surface mine reclaimed zero years ago, etc., and Pasture is an unmined pasture. On each site, three $1,000 \mathrm{~m}^{2}$ plots were delineated, and averages of three measurements on each plot were used as the statistical unit of analysis. Water holding capacity was determined by removing an intact $10 \mathrm{~cm}$ deep core of soil, saturating the core with water, allowing the core to drain at $4^{\circ} \mathrm{C}$, weighing, drying to constant mass, and weighing again. WHC is the ratio water held after drainage to dry mass of soil. Bars that don't share a letter are different by Tukey HSD $\alpha=0.05$.

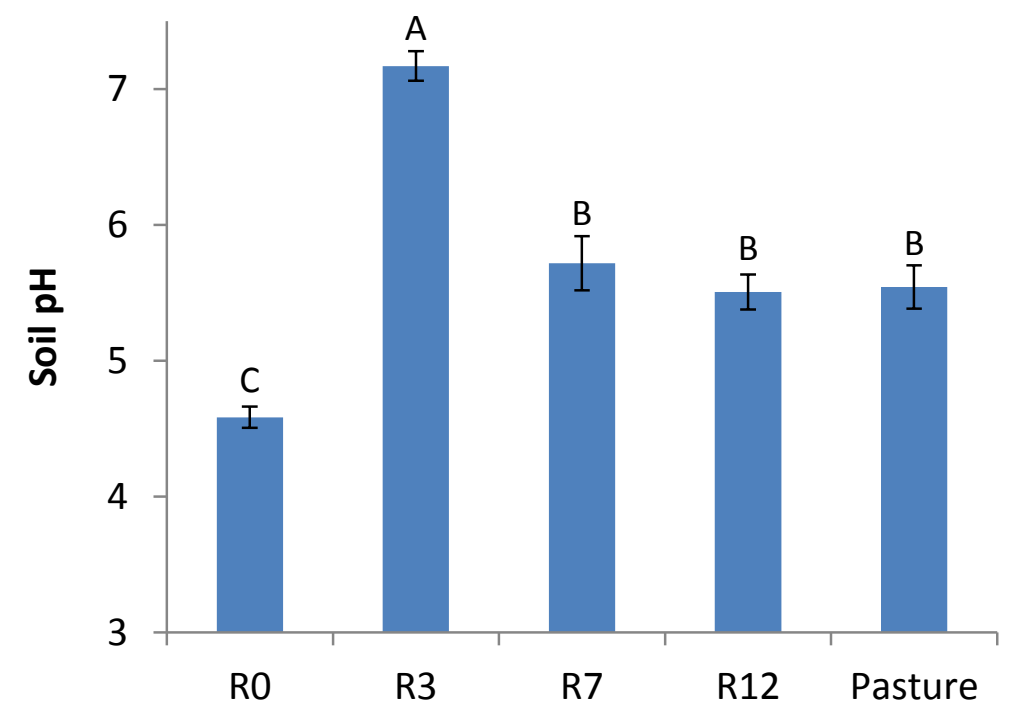

Figure 2.4. Soil pH of reclaimed surface mines of various ages. Soil pH was measured in a 5:1 water:soil slurry. RO is a surface mine reclaimed zero years ago, etc., and Pasture is an unmined pasture. For each site, $\mathrm{pH}$ measurements were made on a mix of soil collected to $10 \mathrm{~cm}$ depth at four points in a stratifiedrandom design from each of three $1,000 \mathrm{~m}^{2}$ plots. Bars that don't share a letter are different by Tukey HSD $\alpha=0.05$. 
Table 2.1. Extractable cations of soils of reclaimed surface mines of various ages. Values are $\mathrm{mg} / \mathrm{kg} \pm$ standard errors.

\begin{tabular}{lcccccccc}
\hline \hline Site & $\mathrm{K}^{*}$ & $\mathrm{Ca} * *$ & $\mathrm{Mg}^{* * *}$ & $\mathrm{Mn} *$ & $\mathrm{Zn}^{* *}$ & $\mathrm{~Pb}^{* *}$ & $\mathrm{Cr}$ \\
\hline R0 & $103 \pm 0.3^{\mathrm{a}}$ & $564 \pm 43^{\mathrm{c}}$ & $114 \pm 2^{\mathrm{c}}$ & $228 \pm 16^{\mathrm{a}}$ & $2.5 \pm 0.1^{\mathrm{a}}$ & $2.1 \pm 0.1^{\mathrm{b}}$ & $0.17 \pm 0.01^{\mathrm{a}}$ & $\mathrm{Cd}^{* *} \cdot \mathrm{I}^{\mathrm{c}}$ \\
R3 & $116 \pm 7.5^{\mathrm{a}}$ & $5,388 \pm 272^{\mathrm{a}}$ & $282 \pm 11^{\mathrm{a}}$ & $200 \pm 15^{\mathrm{ab}}$ & $2.4 \pm 0.2^{\mathrm{a}}$ & $1.9 \pm 0.1^{\mathrm{b}}$ & $0.13 \pm 0.03^{\mathrm{a}}$ & $0.02 \pm 0.006^{\mathrm{ab}}$ \\
R7 & $145 \pm 6.3^{\mathrm{a}}$ & $2,472 \pm 40^{\mathrm{ab}}$ & $259 \pm 9^{\mathrm{a}}$ & $135 \pm 16^{\mathrm{ab}}$ & $5.9 \pm 1.8^{\mathrm{b}}$ & $1.8 \pm 0.2^{\mathrm{b}}$ & $0.21 \pm 0.09^{\mathrm{a}}$ & $0.11 \pm 0.092^{\mathrm{ab}}$ \\
R12 & $143 \pm 14.1^{\mathrm{a}}$ & $3,308 \pm 798^{\mathrm{ab}}$ & $181 \pm 12^{\mathrm{b}}$ & $98 \pm 16^{\mathrm{b}}$ & $2.6 \pm 0.3^{\mathrm{a}}$ & $0.9 \pm 0.3^{\mathrm{b}}$ & $0.13 \pm 0.03^{\mathrm{a}}$ & $0.01 \pm 0.003^{\mathrm{b}}$ \\
Pasture & $99 \pm 19.1^{\mathrm{a}}$ & $1,854 \pm 559^{\mathrm{b}}$ & $88 \pm 10^{\mathrm{c}}$ & $191 \pm 46^{\mathrm{ab}}$ & $4.9 \pm 0.6^{\mathrm{ab}}$ & $4.2 \pm 0.9^{\mathrm{a}}$ & $0.15 \pm 0.02^{\mathrm{a}}$ & $0.18 \pm 0.035^{\mathrm{a}}$ \\
\hline
\end{tabular}

Note: Metals were extracted with Mehlich 3 extractant from a mix of soil collected at four points in a stratified-random design from each of three

$1,000 \mathrm{~m}^{2}$ plots on each site. RO is a surface mine reclaimed zero years ago, etc., and Pasture is an unmined pasture. Differences among sites by ANOVA: ${ }^{*} p<$ $0.05, * * p<0.01, * * * p<0.001$. Ca, $\mathrm{Zn}$, and Cd values were In-transformed to meet normality assumptions. An entry of "b.d.l." indicates an amount below the limit of detection of the instrument used. 
a

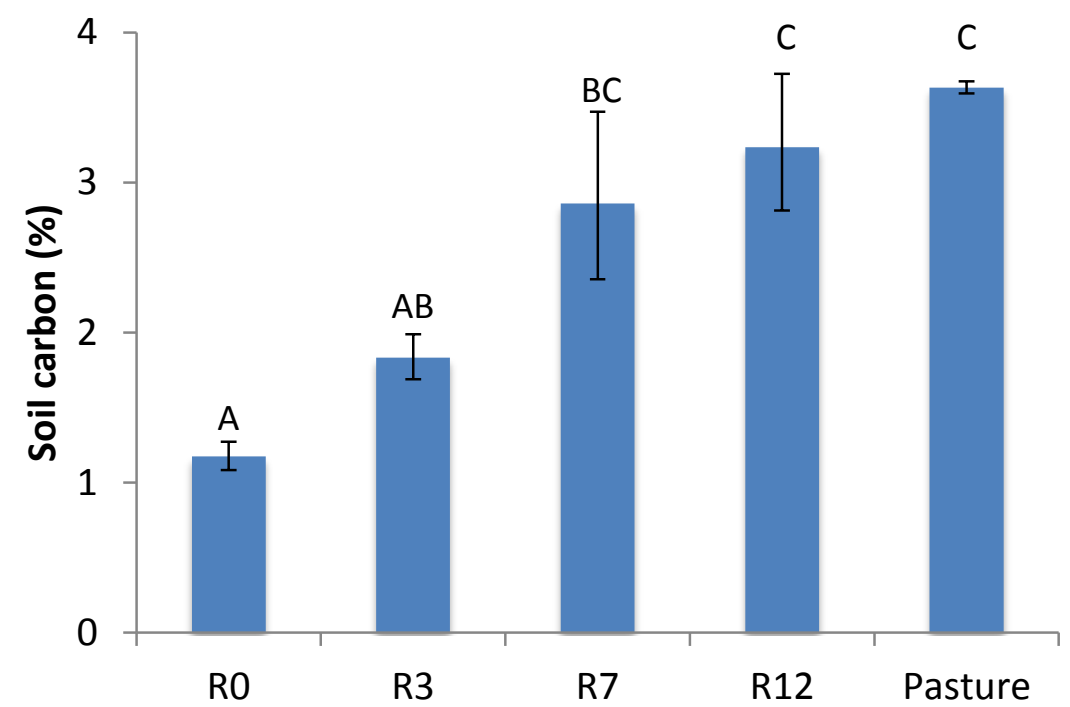

b

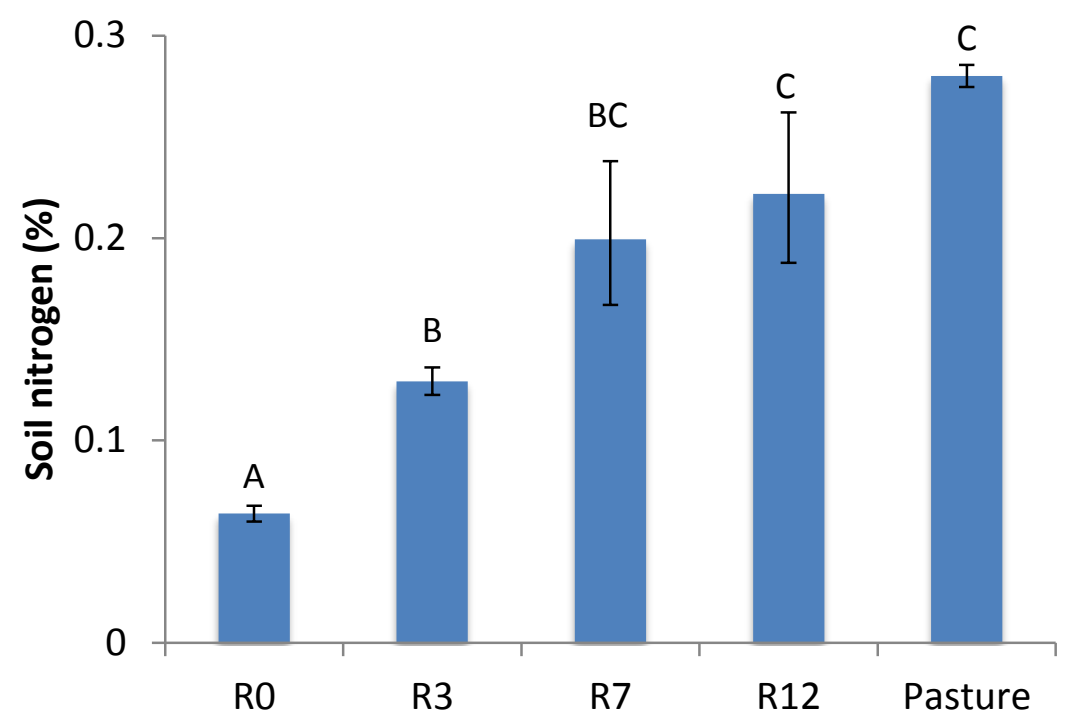

Figure 2.5. Soil carbon (a) and nitrogen (b) of reclaimed surface mines of various ages. Soil $\mathrm{C}$ and $\mathrm{N}$ were measured by combustion with a Carlo Erba elemental analyzer on a soil collected to $10 \mathrm{~cm}$ depth at four points in a stratified-random design from each of three $1,000 \mathrm{~m}^{2}$ plots on each site. $\mathrm{R} 0$ is a surface mine reclaimed zero years ago, etc., and Pasture is an unmined pasture. Data were In-transformed to meet assumptions of normality and are presented here backtransformed. Bars that don't share a letter are different by Tukey HSD $\alpha=0.05$. 
Table 2.2. Inorganic and organic $P$ in sequential extractions from soils of reclaimed surface mines of various ages. Values are $\mathrm{mg} / \mathrm{kg} \pm$ standard errors.

\begin{tabular}{lccccccc}
\hline \hline & \multicolumn{3}{c}{$\mathrm{P}_{\mathrm{i}}$} & & \multicolumn{2}{c}{$\mathrm{P}_{\mathrm{o}}$} \\
\cline { 2 - 3 } Site & $\mathrm{CaCl}_{2}{ }^{*}$ & $\mathrm{NH}_{4} \mathrm{Cl}^{* *}$ & Mehlich 3** & & $\mathrm{CaCl}_{2}{ }^{* * *}$ & $\mathrm{NH}_{4} \mathrm{Cl}^{*}$ & Mehlich $3^{* * *}$ \\
\hline R0 & $0.10 \pm 0.01^{\mathrm{ab}}$ & $0^{\mathrm{b}}$ & $4.97 \pm 1.41^{\mathrm{b}}$ & & $0^{\mathrm{c}}$ & $0.03 \pm 0.03^{\mathrm{b}}$ & $0.09 \pm 0.07^{\mathrm{b}}$ \\
R3 & $0.02 \pm 0.01^{\mathrm{b}}$ & $0.01 \pm 0.01^{\mathrm{b}}$ & $106.79 \pm 59.87^{\mathrm{a}}$ & & $0.03 \pm 0.03^{\mathrm{c}}$ & $0.07 \pm 0.07^{\mathrm{ab}}$ & $0^{\mathrm{b}}$ \\
R7 & $0.12 \pm 0.04^{\mathrm{ab}}$ & $0^{\mathrm{b}}$ & $10.12 \pm 2.3^{\mathrm{b}}$ & & $0.47 \pm 0.06^{\mathrm{bc}}$ & $0^{\mathrm{b}}$ & $0.22 \pm 0.22^{\mathrm{b}}$ \\
R12 & $0.08 \pm 0.02^{\mathrm{ab}}$ & $0^{\mathrm{b}}$ & $8.40 \pm 2.69^{\mathrm{b}}$ & & $0.62 \pm 0.21^{\mathrm{ab}}$ & $0.32 \pm 0.32^{\mathrm{ab}}$ & $0.18 \pm 0.18^{\mathrm{b}}$ \\
Pasture & $0.42 \pm 0.17_{\mathrm{a}}$ & $0.11 \pm 0.04^{\mathrm{a}}$ & $10.47 \pm 1.32^{\mathrm{b}}$ & & $1.3 \pm 0.32^{\mathrm{a}}$ & $0.89 \pm 0.31^{\mathrm{a}}$ & $15.69 \pm 4.87^{\mathrm{a}}$ \\
\hline
\end{tabular}

Note: Phosphorus was extracted sequentially using $0.01 \mathrm{M} \mathrm{CaCl}_{2}$ for $1 \mathrm{~h}, 1 \mathrm{M} \mathrm{NH}_{4} \mathrm{Cl}$ for $30 \mathrm{~min}$, and Mehlich 3 extractant for 5 $\mathrm{min}$ from a mix of soil collected at four points in a stratified-random design from each of three 1,000 $\mathrm{m}^{2}$ plots on each site. R0 is a surface mine reclaimed zero years ago, etc., and Pasture is an unmined pasture. Differences among sites by ANOVA: $* p<0.05, * * p<0.01, * * * p$ $<0.001$. Data were In-transformed for statistical analysis to meet normality assumptions but are presented here in untransformed.

Values that don't share a letter indicate differences within fraction by Tukey HSD $\alpha=0.05$. 


\subsubsection{Arbuscular mycorrhizal fungi}

Arbuscular mycorrhizal fungi were much less infective on the younger PR sites, and infectivity increased with site age, approaching levels found on Pasture for R12 (Figure 2.6; $p<0.001$ ). Plant-host species were not differentially colonized $(p=0.186)$; however, AMF from the younger sites preferentially colonized the $\mathrm{C} 4$ grass, AMF from the older sites showed no preference for either grass, and AMF from Pasture preferentially colonized the C3 grass (site $x$ host effect, $p=0.040$ ).

AMF species richness was reduced on PR sites relative to the unmined reference pasture (Figure 2.7; $p=0.001$ ). In total, 11 species morphotypes were recovered from unmined pasture, versus six or seven from each of the PR sites. With the exception of Acaulospora koskei, recovered from $\mathrm{R} 0$, all of the fungi recovered from the PR sites were also recovered from Pasture. Scutellospora heterogama was the only species recovered from Pasture that was not also recovered from at least one of the PR sites (Table 2.3). 


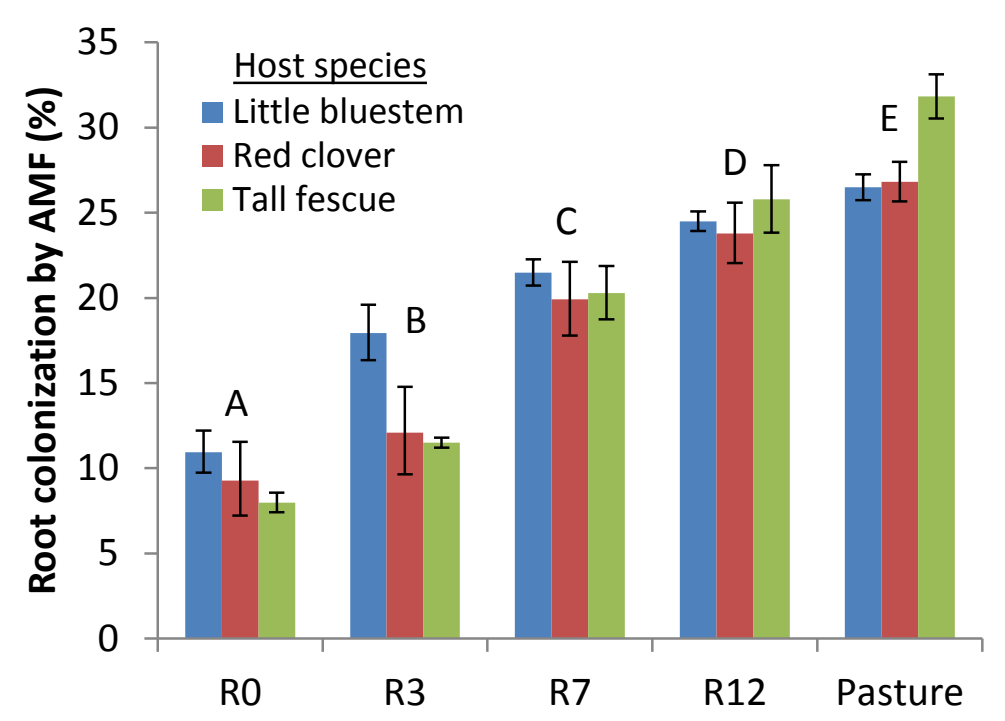

Figure 2.6. Mycorrhizal inoculum potential of reclaimed surface mines of various ages. Plant roots were assessed for colonization after 30 days growth. Data were arcsine-transformed to meet assumptions of normality and are presented here backtransformed. Letters indicate significant differences among sites only by Tukey HSD $\alpha=0.05$.

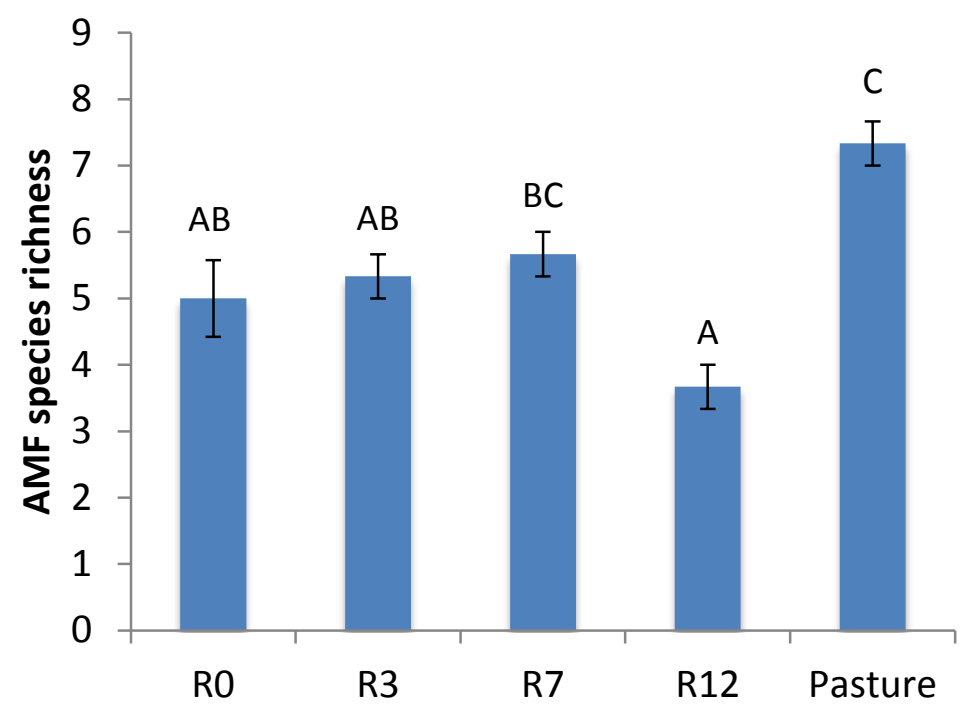

Figure 2.7. Average number of AMF species morphotypes per plot recovered from trap cultures from reclaimed surface mines of various ages. Inocula for trap pots were collected to $10 \mathrm{~cm}$ depth from three points within each of three plots on each site in a stratified-random design. Chopped roots were mixed 1:1 with course sand in $15 \mathrm{~cm}$ pots and seeded with 100 seeds sudangrass. Trap pots were grown for 90 days in a greenhouse before being allowed to dry. Spores were recovered using sucrose centrifugation and identified using descriptions from the International Culture Collection of Arbuscular Mycorrhizal Fungi website: invam.caf.wvu.edu. 
Table 2.3. Communities of arbuscular mycorrhizal fungi recovered from trap cultures from reclaimed surface mines of various ages.

\begin{tabular}{|c|c|c|c|c|c|}
\hline RO & R3 & $\mathrm{R} 7$ & $\mathrm{R} 12$ & Pasture & $\begin{array}{l}\text { Likelihood- } \\
\text { ratio } p\end{array}$ \\
\hline \multirow[t]{3}{*}{ Acaulospora koskei (3) } & & & & & 0.005 \\
\hline & Archaeospora trappei (2) & & & Archaeospora trappei (3) & 0.004 \\
\hline & & Entrophospora infrequens (3) & Entrophospora infrequens (2) & Entrophospora infrequens (1) & 0.014 \\
\hline Glomus clarum (3) & & & Glomus clarum (1) & Glomus clarum (1) & 0.022 \\
\hline G. diaphanum (1) & & & & G. diaphanum (3) & 0.009 \\
\hline \multirow[t]{3}{*}{ G. eburneum (1) } & G. eburneum (3) & G. eburneum (2) & G. eburneum (3) & G. eburneum (1) & 0.106 \\
\hline & G. intraradices (2) & G. intraradices (3) & G. intraradices (1) & G. intraradices (3) & 0.014 \\
\hline & G. mosseae (3) & G. mosseae (3) & G. mosseae (1) & G. mosseae (2) & 0.014 \\
\hline G. spurcum (3) & G. spurcum (3) & G. spurcum (3) & G. spurcum (1) & G. spurcum (2) & 0.117 \\
\hline \multirow[t]{2}{*}{ Paraglomus occultum (3) } & Paraglomus occultum (3) & Paraglomus occultum (3) & Paraglomus occultum (2) & Paraglomus occultum (2) & 0.387 \\
\hline & & & & Scutellospora heterogama (2) & 0.093 \\
\hline S. pellucida (1) & & & & S. pellucida (2) & 0.117 \\
\hline
\end{tabular}

Note: Parenthetical numbers indicate from how many of a site's three trap pots that morphospecies was recovered. Likelihood-ratio $p$-values indicate the

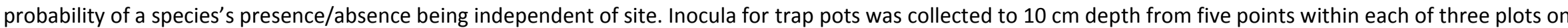
each site in a stratified-random design. Chopped roots were mixed 1:1 with course sand in $15 \mathrm{~cm}$ pots and seeded with $\sim 100$ seeds sudangrass. Trap pots were grown for 90 days in a greenhouse before being allowed to dry. Spores were recovered using sucrose centrifugation and identified using descriptions from the International Culture Collection of Arbuscular Mycorrhizal Fungi website: invam.caf.wvu.edu. 


\subsubsection{Vegetation}

Plant community composition was assessed in two rounds of surveying (Figure 2.8). A complete list of species observed can be found in Appendix A. There were more species present per plot on the older mine sites than the younger sites and more than twice as many on Pasture than any of the PR sites (Figure 2.9; $\mathrm{p}<0.001$ ). Diversity, as measured by the Shannon Index, also differed among sites, following a pattern generally similar to that found for species richness, but with more recovery by R12 (Figure 2.10; $p<0.001$ ). Plant species were categorized according to threat of invasiveness in West Virginia, and the percentage of species belonging to each of the four threat levels differed significantly among sites (Figure 2.11, p-values for each category $\leq 0.01)$. RO had no severely invasive plants and a smaller fraction of its community composed of invasive plants of any category than the other PR sites. A greater fraction of plant species on R3 were invasive-both the most severely invasive and among all invasiveness categories-than the other sites, and there was a trend toward a greater contribution of native and less-severely invasive plants among the older PR sites.

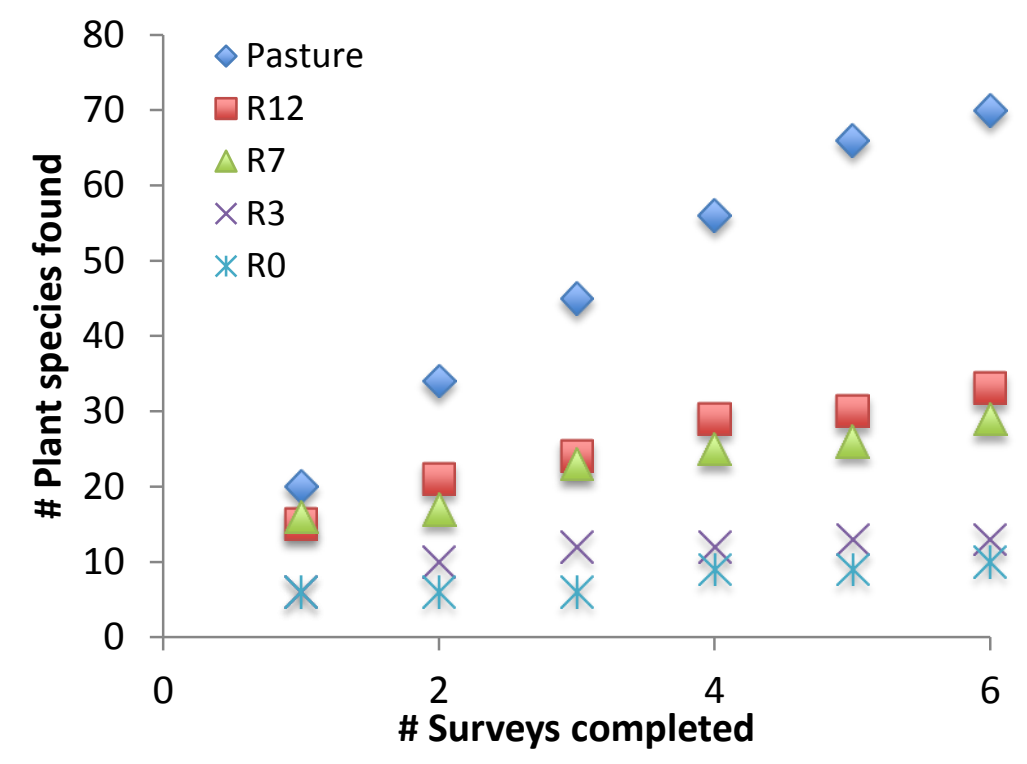

Figure 2.8. Plant species accumulation curves for reclaimed surface mines of various ages. In lateJune/early-July, 2010 species were identified in a $10 \mathrm{~m}^{2}$ area within each plot (surveys $1-3$ ). In lateAugust/early-September, 2010, species were identified in three $0.25 \mathrm{~m}^{2}$ quadrats within each plot (surveys 4-6). 


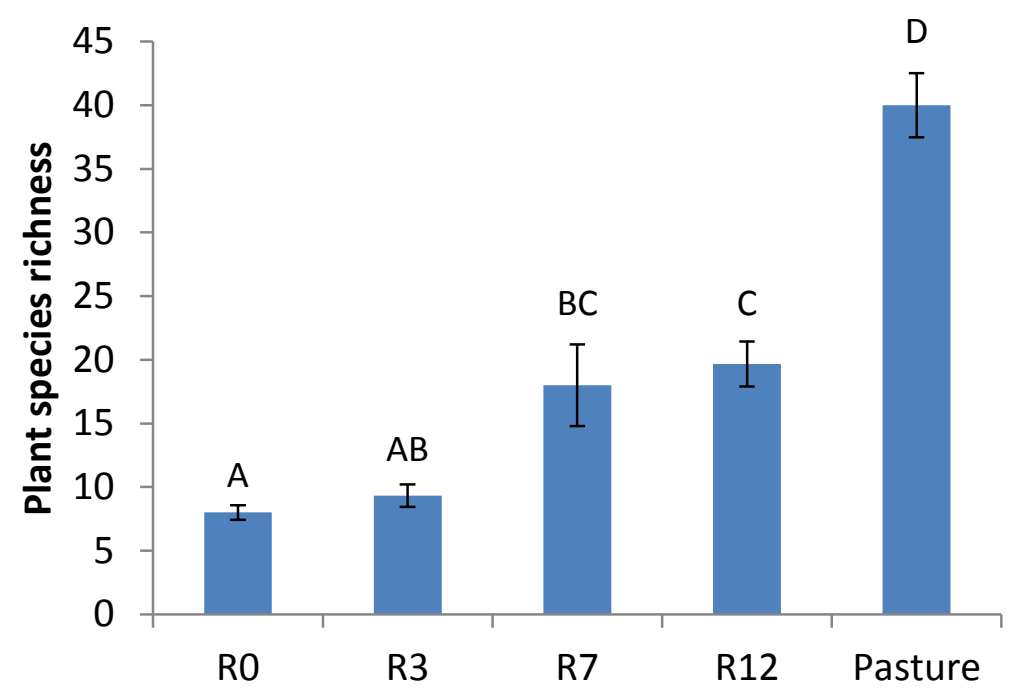

Figure 2.9. Number of plant species present per plot on reclaimed surface mines of various ages. R0 is a surface mine reclaimed zero years ago, etc., and Pasture is an unmined pasture. For each of three plots on each site, species were identified in a $10 \mathrm{~m}^{2}$ area in late-June/early-July and in three $0.25 \mathrm{~m}^{2}$ quadrats in late-August/early-September, 2010.

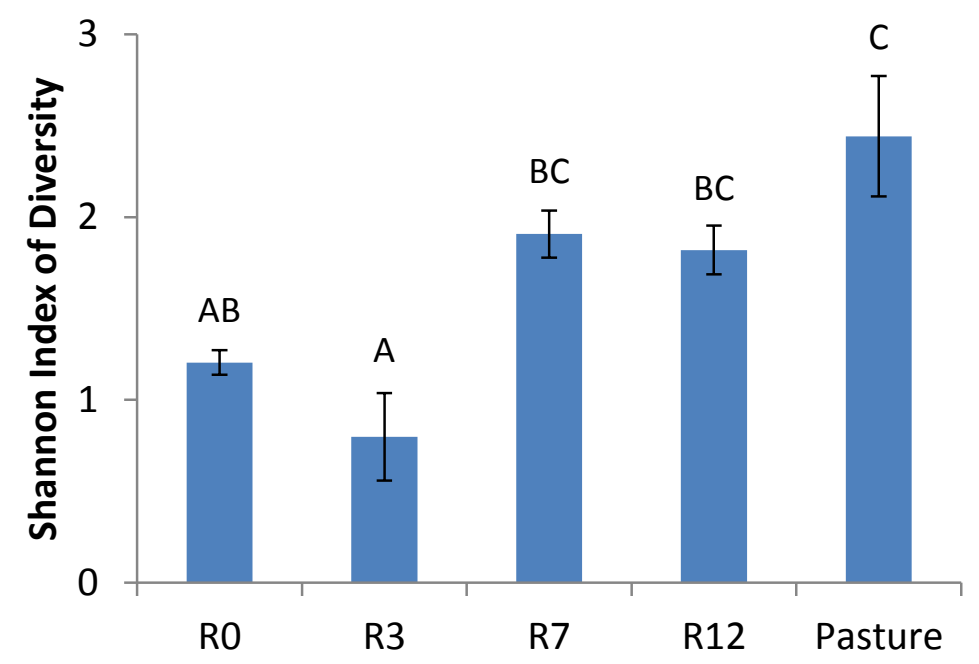

Figure 2.10. Shannon Index of Diversity reflects plant species richness and evenness on reclaimed surface mines of various ages. RO is a surface mine reclaimed zero years ago, etc., and Pasture is an unmined pasture. In late-August/early-September, 2010, on each of three plots on each site, three 0.25 $\mathrm{m}^{2}$ quadrats, distributed in a stratified-random design, were quantitatively surveyed. Shannon index was calculated on the number of individuals present in the $0.75 \mathrm{~m}^{2}$ area surveyed on each plot. 


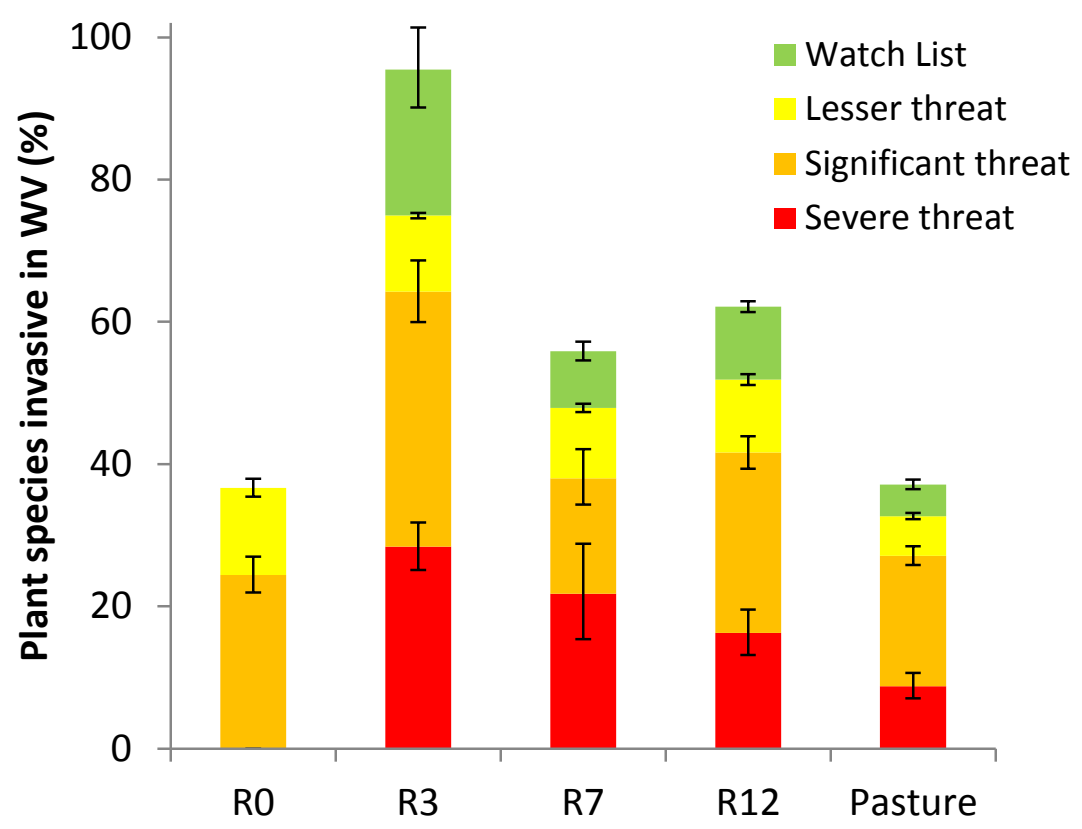

Figure 2.11. Plant community composition by invasiveness on reclaimed surface mines of various ages. Plant species were categorized by invasiveness threat according to the West Virginia Native Plant Society's Checklist of the Invasive Plant Species of West Virginia. For more details on interpretation of categories, refer to the methods section. RO is a surface mine reclaimed zero years ago, etc., and Pasture is an unmined pasture. Plant surveys were completed in late-June/early-July and late-August/earlySeptember, 2010. Percentages were derived from species present on each of three $1,000 \mathrm{~m}^{2}$ plots on each site and used for statistical analysis following arc-sin transformation; graph shows backtransformed data.

\subsection{Discussion}

Surface mining and reclamation to pasture have broad impacts on ecosystem structure and function (Simmons and others 2008). The dramatic changes in soils (Haering and others 2004), vegetation communities (Holl 2002), and soil microbial activity and community (Abdul-Kareem and McRae 1984; Harris and others 1989) alter the trajectory of ecosystem recovery of these sites. In the current study, we observed substantial effects of mining and reclamation on soil physical properties, soil chemistry, AMF infectivity and community, and plant community diversity and composition. Some of these changes were reversed partially or completely over a 12-year period following reclamation, others aspects of ecosystem structure seemed to develop little over time after reclamation. 
Soil bulk density was $50 \%$ greater on the most recently reclaimed site (RO) than the unmined pasture (Pasture) (Figure 2.2). On R12, but not R3 or R7, bulk density was significantly less than on RO, suggesting some amelioration of soil compaction may occur in the short-to-medium term after reclamation. However, Haering and others (2004) found no relationship of site age and soil development, and our survey of other PR surface mines in the area (Appendix B) suggest that recovery of soil bulk density with time in the short-to-medium term is unlikely. Therefore, the difference in bulk density between R12 and the other PR sites is likely a result of differences in overburden material or mining/reclamation methods.

Soil water holding capacity was reduced to nearly half on all the reclaimed mines relative to the unmined pasture and showed no significant trend of changing over time (Figure 2.3). Water retention is important for plant root growth, nutrient acquisition, and mycorrhizae formation (Nadian and others 1997). It has previously been demonstrated that soil compaction on reclaimed mines reduces rainwater infiltration, leading to higher peak runoff (Negley and Eshleman 2006). The combination of increased bulk density and decreased water holding capacity of soil observed here may indicate reduced rainwater storage capacity and increased peak flow rates off of, and downstream from, reclaimed mines.

Soil pH was nearly identical on R7, R12, and Pasture (Figure 2.4), albeit more alkaline than the natural soil of the region. This likely reflects similar management techniques on reclaimed and unmined pasture, as the $\mathrm{pH}$ on these sites $(\sim 5.6)$ is toward the acidic end of the ideal range for many pasture crops (Havlin and others 2005). If the spike in $\mathrm{pH}$ seen from R0 to R3 and R7 reflects a typical pattern of naturally acidic soil being heavily limed and that lime then being consumed with a corresponding drop in $\mathrm{pH}$, the rapidity of change could be destabilizing as plants and microbes that thrive in acidic soil may struggle in alkaline soil and vise-versa. These edaphic stresses may then impact the successful establishment of vegetation and soil microbial communities on PR sites.

The patterns of variation of cation levels across sites were inconsistent (Table 2.1). Levels of heavy metals $(\mathrm{Cd}, \mathrm{Cr}, \mathrm{Pb}, \mathrm{Zn}$, and $\mathrm{Mn})$ in the top $10 \mathrm{~cm}$ of soil were not highly elevated on the PR sites, suggesting that heavy metal contamination from the use of fly ash in reclamation-at 
least as practiced on these sites-is unlikely. Interestingly, $\mathrm{Pb}$ levels were highest on the unmined site, likely as a consequence of $\mathrm{Pb}$ that had accumulated on the surface of soils prior to the banning of $\mathrm{Pb}$ in gasoline and that $\mathrm{Pb}$ subsequently being distributed throughout the soil column by the stockpiling and respreading processes associated with mining and reclamation (Miller and Friedland 1994).

Soil organic matter in the top $10 \mathrm{~cm}$, measured as soil C and $\mathrm{N}$, was roughly one-third the level of the unmined pasture immediately after mining, but was not significantly different from the unmined pasture on R7 and R12 (Figure 2.5). This rapid accumulation of SOM is likely beneficial to plants and the ecosystem as a whole, as SOM increases cation exchange capacity of soil, provides nutrients to microbes and plants, and improves soil structure (Brady and Weil 2007). However, most (Rawls and others 2003), but not all (Danalatos and others 1994), studies that have investigated organic matter and water retention have found a direct correlation between the two. In this study, while SOM accumulated rapidly on the reclaimed mines, WHC remained low relative to the unmined pasture (Figure 2.3). It is possible that SOM is accumulating on the soil surface of reclaimed mines rather than being mixed into deeper horizons where it would likely have greater functional effect. Our findings contrast with those of Simmons and others (2008), who found $C$ and $N$ in both the $O$ and $A$ horizons of a 15 -year old reclaimed mine to be roughly half that of a reference watershed.

Inorganic phosphorus far exceeded organic phosphorus on all the reclaimed sites, but not on the unmined pasture (Table 2.2). Total (sum of fractions) $P_{i}$ was consistent across all sites, with the exception of R3, where there was roughly an order of magnitude more Mehlich 3extractable $\mathrm{P}_{\mathrm{i}}$ than any other site. This could be the result of heavy application of rock phosphate on R3, which would explain the high Ca (Table 2.1) and pH (Figure 2.4) on R3. However, Mehlich 3 extractant is best suited to acidic soils and has been found to extract proportionally more $\mathrm{P}$ in neutral-alkaline soils than other extractants (Buondonno and others 1992), so while $P_{i}$ is likely elevated on $R 3$, the extent of elevation may have been exaggerated by the use of Mehlich 3 as an extractant. 
Water-extractable $P_{i}$ and $P_{0}$ were present on the unmined site at levels more than twice that of any reclaimed site (Table 2.2). Water-extractable $P$ has been shown to be a good predictor of plant yield (Luscombe and others 1979), so lower levels of this highly labile P may limit plant productivity, even when Mehlich 3-extractable $P$ levels are similar. On the other hand, waterextractable $P$ is a better predictor of potential for runoff of both total and reactive $P$ than Mehlich 3-extractable P (Schroeder and others 2004), so the lower levels of water-extractable P found on the reclaimed mines may indicate low potential for $\mathrm{P}$ eutrophication in surrounding bodies of water.

Infectivity of mycorrhizal fungi on the most-recently reclaimed site was approximately twothirds less than the unmined site; however, infectivity-regardless of plant host speciesreturned to nearly unmined levels on R12 (Figure 2.6). Fungi preferentially infected $S$. scoparium on the younger sites and $F$. arundinacea on the older and unmined sites. This may reflect a shift in preference from faster-growing C4 grasses on the younger sites to slowergrowing C3 grasses on the older sites. Alternatively, Bever (2002) and Zhang and others (2010) have demonstrated that plant and AMF species can form positive feedback loops by mutuallyselecting for each other to the exclusion of other species. F. arundinacea is invasive in WV, is often the dominant grass on reclaimed surface mines (Zipper and others 2011), and was observed on R7, R12, and Pasture, but not on R0 or R3. It is possible that F. arundinacea entrenches itself by preferentially delivering carbon to AMF that, in turn, preferentially benefit F. arundinacea.

In general, there were less species of AMF per plot on the reclaimed mines than the unmined pasture (Figure 2.7). Similarly, across plots, 11 AMF species were recovered on the unmined pasture, versus six or seven species on each of the reclaimed sites (Table 2.3). One species was found on the unmined site that wasn't found on any of the mined sites (Scutellospora heterogama), and three species that were found on the unmined site were found on only one other site (Scutellospora pellucida, Archaeospora trappei, and Glomus diaphanum). The AMF species that were found consistently on all or most sites were generally of the Glomus and Paraglomus genera. Egerton-Warburton and others (2007) found that nitrogen fertilization of 
prairies reduced species richness by eliminating rare species while Glomus species were spared. It is possible that a similar mechanism is responsible for our finding fewer non-Glomus species on the reclaimed sites than the reference site, possibly as a consequence of fertilization in reclamation or the other aspects of disturbance brought about by mining and reclamation.

Plant diversity was severely depressed on the youngest reclaimed mines relative to the unmined site and had recovered partially on the older mined sites (Figure 2.9 andFigure 2.10). On average, plots on even the oldest mine contained less than half as many plant species as plots on the unmined site. Of the 89 plant species identified in this study, 36 were found on the unmined reference pasture and at least one reclaimed mine. These plants may have had propagules survive the topsoil stockpiling and respreading processes, may have been seeded after mining, or may have recolonized sites from adjacent areas. In any case, these plants were resilient to mining as it was practiced on these sites. Thirty-four of the 89 plant species identified were found on the reference pasture but none of the reclaimed mines. These species may be intolerant of local conditions on recently reclaimed mines, may be outcompeted by plants that have established themselves on reclaimed sites, or may not have had propagules reach these reclaimed sites. Nineteen of the 89 plant species identified were found on at least one of the reclaimed mines but not the unmined site. These species may have been seeded in reclamation or may be able to take advantage of disturbance or local conditions on reclaimed mines.

Plant species that are considered severely invasive in West Virginia made up the greatest percentage of the plant community on R3, less on R7 and R12, and less-still on Pasture (Figure 2.11), likely as a consequence of more non-invasive species being present on the older and unmined sites. Holl (2002) also observed a pattern of non-native plants colonizing reclaimed sites decreasing with site age. It has been demonstrated that invasive species can disrupt AMF associations of native plants (Stinson and others 2006) and change AMF community composition (Mummey and Rillig 2006). Further investigation is warranted regarding the dynamics of exotic species invasion and entrenchment and changes in the mycorrhizal associations of native plants on disturbed sites. 
Severely invasive plants were notably absent on RO (Figure 2.11). RO also had anomalously low $\mathrm{pH}$ (figure 3) and the most unique AMF community (by clustering, not shown; see table 2). R0 was surveyed after the local hillside had been reclaimed (regraded, topsoil replaced, plants seeded); however, the larger mine was still active. It is possible that additional measures (e.g., liming) occurred after sampling. However, it is also possible that reclamation practices are changing (at least among the more responsive operations), such that native plants are being seeded more and soil is being left near natural $\mathrm{pH}$ for the region. In agreement with our findings, Zipper and others (2011) recently reported that exotic invasive plants (undefined in the study) covered an average of $16 \%$ of land area on 20 post-SMCRA-reclaimed surface mines in Appalachia.

In many respects-soil pH, plant community, AMF community, and Mehlich 3-extractable $\mathrm{P}_{\mathrm{i}}-$ R0 and R3 represent endmembers of the spectrum of sites examined in this study. They are, however, separated by less than $1 \mathrm{~km}$ and were mined by the same operation, separated by just three years. Differences between the two are thus very likely to be the consequence of different reclamation practices. Paired comparisons of the two sites as they develop over time would be valuable for the reclamation community.

In conclusion, surface mining with concurrent reclamation to pasture represents a massive ecosystem disturbance. Some facets of ecosystem structure return rapidly to levels similar to that of an unmined site, including many aspects of soil chemistry. Other aspects of ecosystem structure show partial recovery over the 12-year period examined here, including AMF infectivity and plant species diversity. Still other facets of ecosystem structure showed no signs of recovery over 12 years, including soil bulk density and water holding capacity and AMF community composition. Reclamation practices that promote the development of ecosystem structure toward that of undisturbed sites should be identified and adopted. 


\section{Phosphorus stress response of red clover inoculated with arbuscular mycorrhizal fungal communities from reclaimed surface mines}

\subsection{Introduction}

In West Virginia, and Central Appalachia in general, surface mining and concurrent reclamation is the primary driver of land use and cover change (Brown and others 2005; Townsend and others 2009). Likely because it offers the fastest path to bond release (McElfish and Daniels 1990), the most common reclamation practice in this region is to reclaim the land to pasture post-mine use (Plass 2000). In pasture reclamation (PR) in northern West Virginia, topsoil is stockpiled, stored during mining, and respread on top of blasted overburden and layer of alkaline flyash used to limit water infiltration to potentially acidifying overburden (Skousen and others 2009). The respread topsoil is generally compacted by multiple passes of heavy machinery, limed, fertilized, and seeded with a mix of grasses and herbaceous plants, some of which may be native to the region and some of which may be aggressive and exotic (Holl 2002; Skousen and others 2009; Zipper and others 2011).

The processes of mining and reclamation have lasting, deleterious effects on ecosystem structure and function. Plant communities develop toward those found on unmined sites but many plants have not been observed returning to PR sites (Holl 2002), and exotic invasive species can become established (Zipper and others 2011). Soil microbial biomass, diversity, and activity are diminished by topsoil stockpiling and reclamation (Abdul-Kareem and McRae 1984; Harris and others 1989; Simmons and others 2008). Soil physical properties (Haering and others 2004) and nutrient levels (Indorante and others 1981; Simmons and others 2008) are often altered on PR sites. The altered soil chemistry, microbial activity, and plant communities of PR sites make the trajectory and pace of succession and ecosystem development uncertain.

Soil P levels fluctuate widely in the upper soil horizons on PR sites (Table 2.2), presumably as a result of varying fertilization practices and nutrient dilution in the upper soil horizons as a consequence of homogenization from soil stripping and respreading. Plants have myriad 
strategies for accessing scarce $\mathrm{P}$, including altering root structure, exudation of organic acids, protons, and enzymes, upregulation of enzymes related to $\mathrm{P}$ uptake, and acquisition through symbioses with mycorrhizal fungi (Roemer 2006; Vance and others 2003).

Over $80 \%$ of terrestrial plant species form symbioses with arbuscular mycorrhizal fungi (AMF), and plant root and AMF functioning are tightly integrated as a result of hundreds of millions of years of coevolution (Schussler and others 2001; Smith and Smith 2011). AMF can ameliorate a variety of plant stresses, including hydrologic stress (Miransari 2010), metal stress (Cumming and Ning 2003), and microbial attack (Whipps 2004); however, AMF are especially important for plants under P stress (Smith and Read 2008). Plant-AMF symbioses can access more P from the same soil than non-mycorrhizal plants, likely as a result of the ability of fungal hyphae to access soil regions that are inaccessible to the larger plant roots (Marschner 1995). Plants may have positive or negative growth responses to colonization by various AMF (Klironomos 2003), but especially when poorly available $\mathrm{P}$ is present in soil, AMF-colonized plants tend to be more successful than non-mycorrhizal plants (Smith and Smith 2011).

Many of the stressful conditions that plants are likely to encounter on PR sites (P stress, compacted soil, water stress) could be alleviated by AMF. However, edaphic conditions also affect the ability of AMF to form functional symbioses (Entry and others 2002), and the stresses experienced during and after mining and reclamation may be particularly deleterious to AMF. The topsoil stockpiling process reduces mycorrhizal infectivity (Gould and Liberta 1981), and the application of NPK fertilizer reduces AMF root colonization and hyphal length (Gryndler and others 2006). AMF infectivity, activity, and diversity might reasonably be expected to be diminished on PR sites; however, reports on such are scarce.

In the arid Powder River Basin, Wyoming, Allen and Allen (1980) found that AMF spore counts and infectivity were roughly half those of an unmined reference site 2-3 years after mining and reclamation. They also observed non-mycorrhizal plant species preferentially colonizing the reclaimed site and hypothesized that this might slow succession on such sites. Frost and others (2001), also working in the arid Powder River Basin, examined a site reclaimed 16 years prior and planted with Wyoming big sagebrush inoculated with native AMF and found a highly 
altered AMF community and reduced spore counts on the reclaimed site relative to an adjacent undisturbed site. In the Czech Republic, Püschel and others (2008) observed rapid return of infectivity of AMF, but found that infectivity could subsequently be diminished by nonmycorrhizal plants.

In previous work (Levy in preparation), we examined PR mines between zero and 12 years old in northern West Virginia and found AMF infectivity increased with time since reclamation, returning nearly to levels observed for an unmined pasture by 12 years. AMF species richness was greater on the unmined site than any of the PR sites, but AMF community varied little between the reclaimed and unmined sites. However, considerable genetic diversity and variation in functional efficacy have been found within AMF species, populations, and even individuals (Ehinger and others 2009; Kelly and others 2005; Munkvold and others 2004). Thus, independent of changes in the AMF community during and after mining, the functional utility of AMF to plants may be affected.

For the current study, we hypothesized that mining and PR would lead to decreased functionality of AMF vis-à-vis $P$ acquisition and this functionality would partially recover over time after reclamation. To test this, we investigated three sites, an 18 year-old PR mine site, a four year-old PR mine site, and an unmined hillside. For each site, we delineated the community of AMF and tested the effects of the AMF community on red clover (Trifolium pretense) under P-limiting and P-sufficient conditions.

\subsection{Methods}

\subsubsection{Selection of sites}

In August 2011, soils were collected from 12 post-SMCRA reclaimed surface mines and three unmined pastures within a $5 \mathrm{~km}$ radius immediately west of Morgantown, WV. Roots and associated soil of 10 red clover (Trifolium pretense) plants, which were common to all sites, were collected from each site and stored in polyethelene bags at $4^{\circ} \mathrm{C}$ until processing. 
Soil $\mathrm{pH}$ was measured in a 1:2.5 soil:water slurry. Soil carbon and nitrogen were measured via combustion with a Carlo Erba NA 1500 elemental analyzer (Carlo Erba Strumentazione, Milan, Italy). Mehlich 3-extractable soil P was measured by malachite green assay (Ohno and Zibilske 1991). Bulk density was determined by extracting a $10 \mathrm{~cm}$ deep $7.5 \mathrm{~cm}$ diameter core, filling the void with a measured volume of fine sand, and drying and weighing the core.

The date when topsoil was replaced on each site was estimated using West Virginia Department of Environmental Protection mine inspection records, primarily the date when inspection reports transitioned from reporting mine status as "active mining" to "active, reclamation only." Dates were confirmed using historical imagery in the computer program Google Earth, noting especially when reclamation began within a site before mining was completed.

All soil data and site permit reference numbers are presented in Appendix B.

A recently reclaimed mine site (WVDEP permit S200801, 5 years post reclamation, designated "Young mine"), an older reclaimed mine site (WVDEP permit S001780, 18 years post reclamation, designated "Old mine"), and an unmined pasture $\left(39.5804^{\circ},-80.093467^{\circ}\right.$; immediately adjacent to a site prepared to be, but not, mined, designated "Unmined") were selected (Figure 3.1) for further investigation based primarily on similar soil pH and extractableP. Red clover was noted to be less prolific on these sites than many of the other sites surveyed. Both of the mined sites were mined and reclaimed by Patriot Mining Company for the Waynesburg coal seam. 


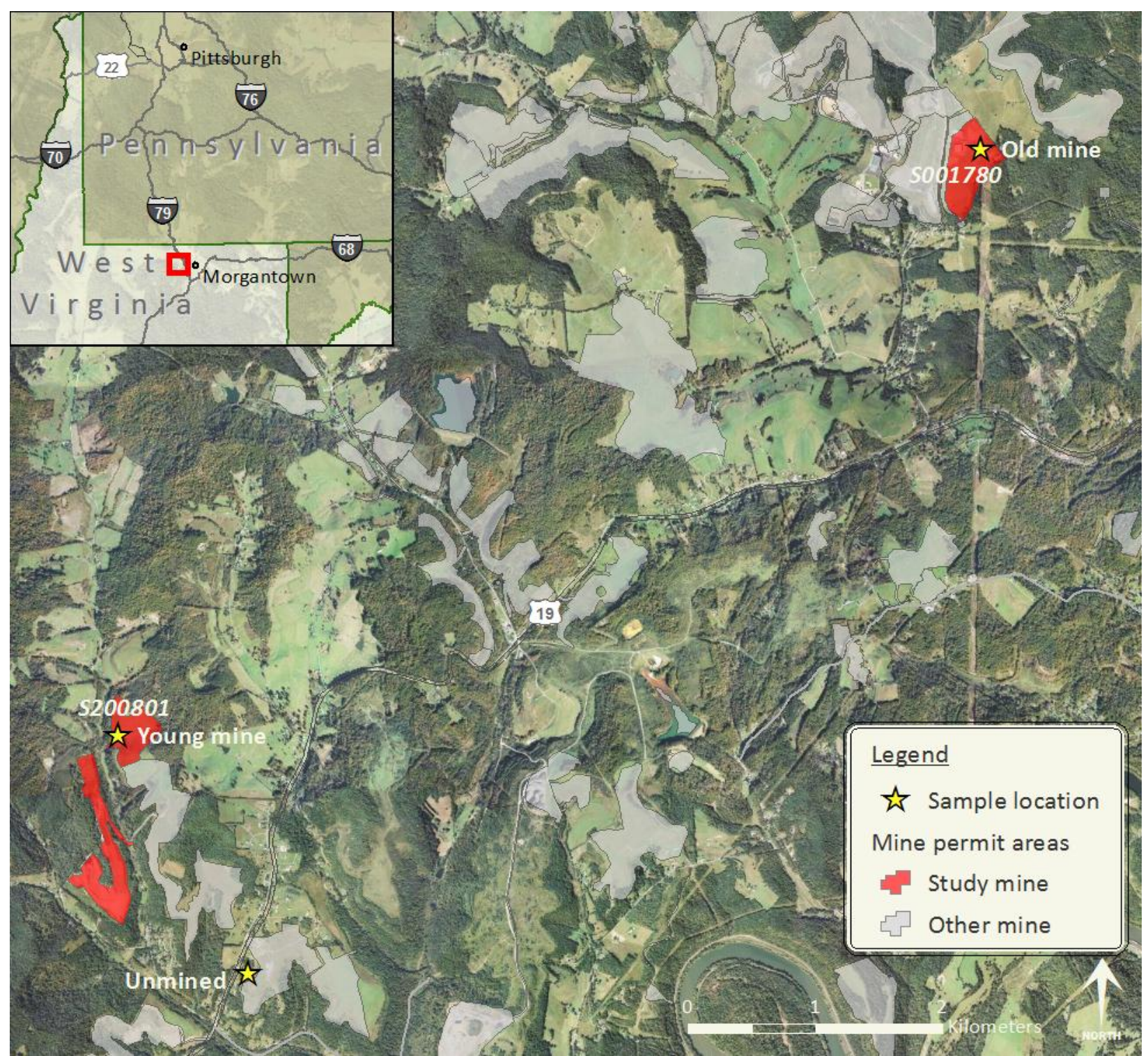

Figure 3.1. Satellite image of sites used in this study. Shaded areas are those permitted for surface mining by the West Virginia Department of Environmental Protection (WVDEP) since 1977. Red areas are the mines studied herein, and italicized numbers are WVDEP permit numbers for those mines. Young mine was mined and reclaimed five year-old prior to study, Old mine 18 years prior, and Unmined is an unmined hillside.

Arbuscular mycorrhizal fungi (AMF) were propagated according to protocols of the International Culture Collection of Arbuscular Mycorrhizal Fungi (INVAM) (Morton 1993). Roots and adhering soil of 10 red clover plants from each site were chopped, mixed 1:1 by volume with sand, and placed in $15 \mathrm{~cm}$ azalea pots. Trap pots were seeded with $100 \mathrm{NaOCl}$-sterilized seeds of sudangrass (Sorghum bicolor subsp. Drummondii). Pot cultures were grown in greenhouse under metal-halide lights for 90 days before being desiccated under ambient 
indoor light for 30 days. Pot contents were chopped and mixed thoroughly and spores recovered from two $50 \mathrm{ml}$ samples from each pot by nest sieving and sucrose centrifugation. AMF species morphotypes were identified using descriptions from the INVAM website (invam.caf.wvu.edu) based on characteristics including size, color, surface texture, spore wall characteristics, and reactivity with Melzer's reagent (Morton 1993). Species morphotypes were recorded as present or absent in each pot (Table 3.1).

Table 3.1. Communities of arbuscular mycorrhizal fungi from trap cultures from a five year-old reclaimed surface mine, an 18 year-old reclaimed surface mine, and an unmined hillside.

\begin{tabular}{lll}
\hline \hline Young mine & Old mine & Unmined \\
\hline $\begin{array}{l}\text { Acaulospora morrowiae } \\
\text { Archeospora trappei }\end{array}$ & $\begin{array}{l}\text { Archeospora trappei } \\
\text { Entrophospora infrequins }\end{array}$ & Archeospora trappei \\
Glomus clarum & $\begin{array}{l}\text { Glomus clarum } \\
\text { G. diaphanum }\end{array}$ & Glomus clarum \\
$\begin{array}{l}\text { G. eburneum } \\
\text { G. etunicatum }\end{array}$ & &
\end{tabular}

G. mosse
G. sinuosum
G. sinuosum
G. sinuosum

G. luteum

G. spercum

G. spercum

Paraglomus occoltum

Paraglomus occoltum

Scutellospora dipurpurascens

S. heterogama

S. pellucida

Note: Inocula for trap pots was taken from roots and adhering soil of 10 red clover plants from each site. Inocula were chopped, mixed 1:1 with course sand in $15 \mathrm{~cm}$ pots and seeded with 100 seeds sudangrass. Trap pots were grown for 90 days in a greenhouse before being allowed to dry. Spores were recovered using sucrose centrifugation and identified using descriptions from the International Culture Collection of Arbuscular Mycorrhizal Fungi website: invam.caf.wvu.edu.

\subsubsection{AMF functionality}

\subsubsection{Experimental Setup}

Inocula were prepared by blending $50 \mathrm{ml}$ of field-clover-root-associated soil and roots 1:1 with water and sieving. Material that passed a $250 \mu \mathrm{m}$ sieve but was retained on a $38 \mu \mathrm{m}$ sieve was mixed with $50 \mathrm{ml}$ sand and added on top of $170 \mathrm{ml}$ of sand in $250 \mathrm{ml}$ Deepots (Stuewe \& Sons, Tangent, OR). Red clover seeds were sterilized in $15 \%$ commercial bleach solution and inoculated with Rhizobium leguminosarum biovar trifoli ("Royal Peat," Becker Underwood, St. 
Joseph, MO). Seeds were placed on the surface of the sand/inocula mix and covered with $\sim 5$ $\mathrm{mm}$ sand. Twelve pots were prepared for each of the three sites $(\mathrm{N}=36)$.

To homogenize non-AMF microbial communities across inocula treatments, a total microbial wash was prepared from a mixture of soil from all three sites and applied to all pots. Soil from the three sites was mixed in equal volumes in a 1:2 ratio with water, blended, and sieved to 38 $\mu \mathrm{m}$, which prevents the passage of AMF propagules but allows smaller microbes to pass (Paulitz and Linderman 1991; Wilson, Hetrick, Kitt 1988). Each pot received $4 \mathrm{ml}$ of sievate.

\subsubsection{Plant propagation}

For four weeks, all plants were provided 0.1-strength modified Johnson's nutrient solution (Johnson and others 1957) consisting of $400 \mu \mathrm{M} \mathrm{KNO}{ }_{3}, 200 \mu \mathrm{M} \mathrm{Ca}\left(\mathrm{NO}_{3}\right)_{2}, 400 \mu \mathrm{M} \mathrm{NH} \mathrm{NO}_{3}, 50$ $\mu \mathrm{M} \mathrm{KH}_{2} \mathrm{PO}_{4}, 100 \mu \mathrm{M} \mathrm{MgSO}_{4}, 20 \mu \mathrm{M} \mathrm{KCl}, 25 \mu \mathrm{M} \mathrm{H}_{3} \mathrm{BO}_{3}, 2 \mu \mathrm{MnSO}_{4}, 2 \mu \mathrm{M} \mathrm{ZnSO}_{4}, 0.5 \mu \mathrm{M} \mathrm{CuSO}_{4}$, $0.5 \mu \mathrm{M} \mathrm{Na}{ }_{2} \mathrm{MoO}_{4}, 0.5 \mu \mathrm{M} \mathrm{CoCl}$, and $20 \mu \mathrm{M}$ FeNa-EDTA at pH 6.0. After 28 days, plants inoculated with each fungal community were divided into $100 \mu \mathrm{M} \mathrm{P}$ and $10 \mu \mathrm{M} \mathrm{P}$ treatment groups. Throughout the experiment, nutrient solutions were delivered in excess of saturation three times daily by an automated pump/manifold system. Plants were maintained in a growth chamber at $70 \%$ relative humidity with $14 \mathrm{~h}$ days at $25^{\circ} \mathrm{C}$ and $\sim 260 \mu \mathrm{mol} / \mathrm{m}^{2} / \mathrm{sec}$ PAR from fluorescent and incandescent bulbs and $10 \mathrm{~h}$ nights at $20^{\circ} \mathrm{C}$. Solution flowing through the root zone of 2-3 pots per P-treatment $x$ inoculum condition was collected with funnels as described by (Lux and Cumming 2001) and termed leachate. Leachate was collected from these pots 2, 5, 12, and 27 days following application of P-treatment. Leachate collections were frozen and stored at $-20^{\circ} \mathrm{C}$ until the end of the experiment, at which time volumes were recorded and inorganic P measured according to He and Honeycutt (2005) to minimize detection of organic P.

\subsubsection{Plant harvest}

Plants were harvested after 30 days of treatment. The evening before harvest, plants received deionized water instead of nutrient solution, and leaf chlorophyll concentration was inferred from measurements taken with a SPAD-502 meter (Konica Minolta, Ramsey, NJ) in triplicate on 
each of eight leaves on each plant. The same eight leaves were removed from the plant and dried at $65^{\circ} \mathrm{C}$ for tissue-P analysis.

The morning of harvest, plants received deionized water sufficient to bring pots to field capacity. Shoots were clipped at the sand surface, washed with distilled water, and dried at $65^{\circ} \mathrm{C}$ for at least $72 \mathrm{~h}$ before being weighed. Pot contents were placed in a beaker and $20 \mathrm{ml}$ of deionized water was washed over them before $10 \mathrm{ml}$ was extracted with an electronic autopipette, filtered to $0.45 \mu \mathrm{m}$, and stored at $-20^{\circ} \mathrm{C}$ for organic acid analysis. After being thoroughly rinsed, approximately $0.2 \mathrm{~g}$ (dry weight) of root tissue from the center of the root system was removed for acid phosphatase (APase) activity analysis. Approximately $0.2 \mathrm{~g}$ (fresh weight) of tissue from the center of the root system was placed in tissue capsules and stored in distilled water at $4^{\circ} \mathrm{C}$ to be analyzed for colonization by AMF. With the exception of the $\sim 0.2 \mathrm{~g}$ root tissue analyzed for colonization by $\mathrm{AMF}$, all tissue was dried at $65^{\circ} \mathrm{C}$ for at least $72 \mathrm{~h}$, weighed, and included in biomass analyses.

\subsubsection{Plant analyses}

To quantify the extent of root colonization by AMF, roots contents were cleared for 15 min in hot $10 \% \mathrm{KOH}$, rinsed five times, twice acidified in $2 \% \mathrm{HCl}$ for $10 \mathrm{~min}$, and stained for $30 \mathrm{~min}$ with hot $0.05 \%$ trypan blue in 1:1:1 water:glycerol:lactic acid. Stained roots were stored in water at $4^{\circ} \mathrm{C}$ for at least 5 days to allow dye to diffuse from uncolonized tissue. Colonization was quantified by the gridline intersect method (Giovannetti and Mosse 1980).

To quantify leaf tissue $P$ concentration, the eight trifoliate leaves that had been analyzed for chlorophyll content and dried at $65^{\circ} \mathrm{C}$ were digested with concentrated $\mathrm{HNO}_{3}$ and $35 \% \mathrm{H}_{2} \mathrm{O}_{2}$ (Jones and Case 1990) and analyzed for total P by molybdate colorimetry (Taussky and Shorr 1953).

To determine APase activity, $0.2 \mathrm{~g}$ (dry weight) of fresh tissue from the center of the root system was placed in a $50 \mathrm{ml}$ centrifuge tube with $9 \mathrm{ml}$ of the nutrient solution that each plant had received during treatment. Following the addition of $1 \mathrm{ml}$ of $\mathrm{pH} 6.0,1 \mathrm{mM} p$ nitrophenylphosphate (NPP), roots were incubated at room temperature while being shaken at 
$180 \mathrm{rpm}$. After $1 \mathrm{~h}, 1 \mathrm{ml}$ of sample was removed and combined with $2 \mathrm{ml}$ of $1 \mathrm{M} \mathrm{NaOH}$, and $p$ nitrophenol was quantified spectrophotometrically (Tabatabai and Bremner 1969). APase activity was calculated on a root dry weight basis.

Solution that had been frozen at harvest for organic acid analysis was lyophilized and reconstituted in $1 \mathrm{ml}$ deionized water. Organic acids were separated with a Bio-Rad Aminex HPX-87H column (Bio-Rad Laboratories, Hercules, CA, USA) using a Dionex ion chromatograph and Chromeleon software (Dionex Corporation, Sunnyvale, CA, USA) as previously described (Smith and others 2011). Because malate and malonate standards produced peaks that could not adequately be resolved, the two were quantified together and are hereafter referred to as "mal(on)ate" or "malate/malonate."

\subsubsection{Data \& statistical analysis}

The experiment was a $3 \times 2$ factorial design, with three fungal inocula sources, two phosphorus levels, and $n=4-6$ ( $n<6$ due to pre-treatment plant mortality). Organic acid production was

normalized to root mass. Phosphorus use index was calculated as $P U I=\frac{\text { total plant biomass }}{\text { leaf P concentration }}$. All measured variables were analyzed via two-way, fixed-effect ANOVA to determine P-treatment, inocula, and interaction effects. Where data did not meet normality assumptions, logarithmic and arcsine transformations were employed. Post-hoc Tukey's HSD test was used to determine differences between specific conditions. Leachate collections were made from the same $2-3$ pots/condition at four times during the experiment; for those data, pot was nested as a random effect within the P-treatment $x$ inoculum term and collection day was used as a co-variate. To explore relationships among measured variables, several ANCOVA were performed. All statistical analyses were performed using SAS JMP version 9.0 (SAS Institute, Cary, NC).

\subsection{Results}

\subsubsection{Plant response}

Clover plants that were provided $100 \mu \mathrm{M}$ P nutrient solution were larger than clover that were provided $10 \mu \mathrm{M}$ P nutrient solution (Figure 3.2; shoot mass $p<0.001$; root mass $p=0.050$ ) and 
had smaller root:shoot ratio $(p<0.001)$. Fungal inoculum had a significant effect on both root $(p<0.001)$ and shoot $(p=0.004)$ biomass, but not root:shoot ratio $(p=0.115)$. Plants inoculated with fungi from the unmined site were significantly larger than plants inoculated with fungi from either of the mined sites (by one-way Tukey HSD). The effect of fungal inoculum on biomass did not depend on the level of phosphorus the plants received $(P \times$ inoculum effect shoot $p=0.462 ;$ root $p=0.639)$.

The extent of colonization of roots by AMF differed among inocula sources (Figure 3.3; $p=$ 0.015), with AMF from the old mine colonizing roots to a greater extent than AMF from the unmined site (by one-way Tukey HSD). There was a trend toward the roots of plants grown with $10 \mu \mathrm{M}$ P being colonized by AMF to a greater extent than those grown in $100 \mu \mathrm{M} P(p=0.087)$. There was a significant negative effect of colonization on plant biomass (Figure 3.4; $p=0.047$ ) that was independent of phosphorus treatment ( $P$-treatment $\times$ colonization effect $p=0.883$ ). 


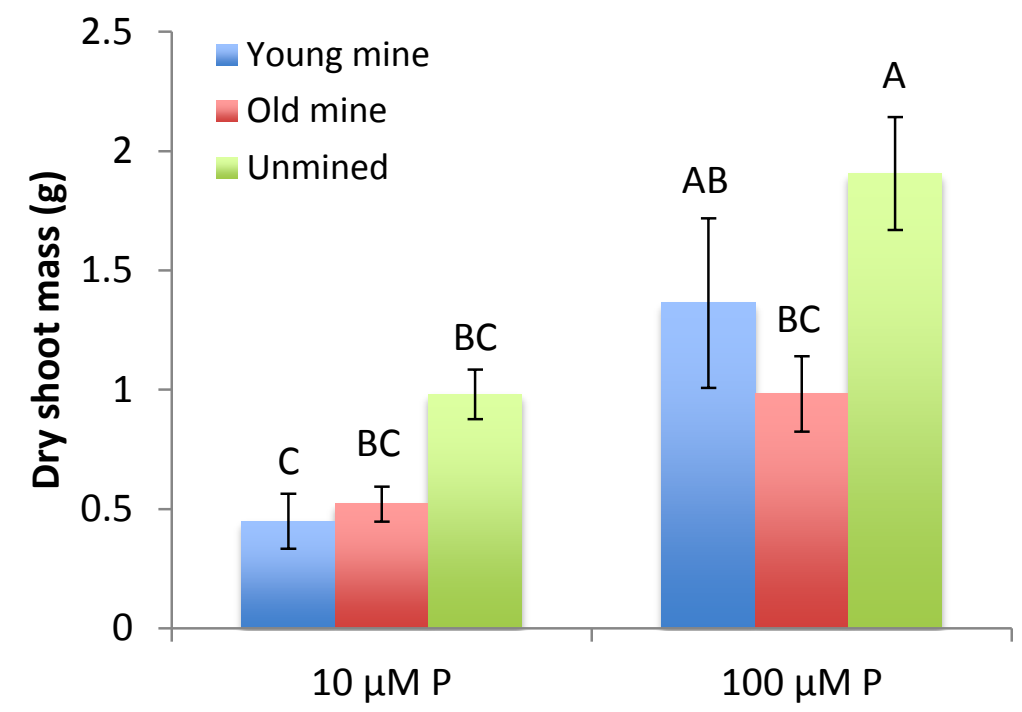

b

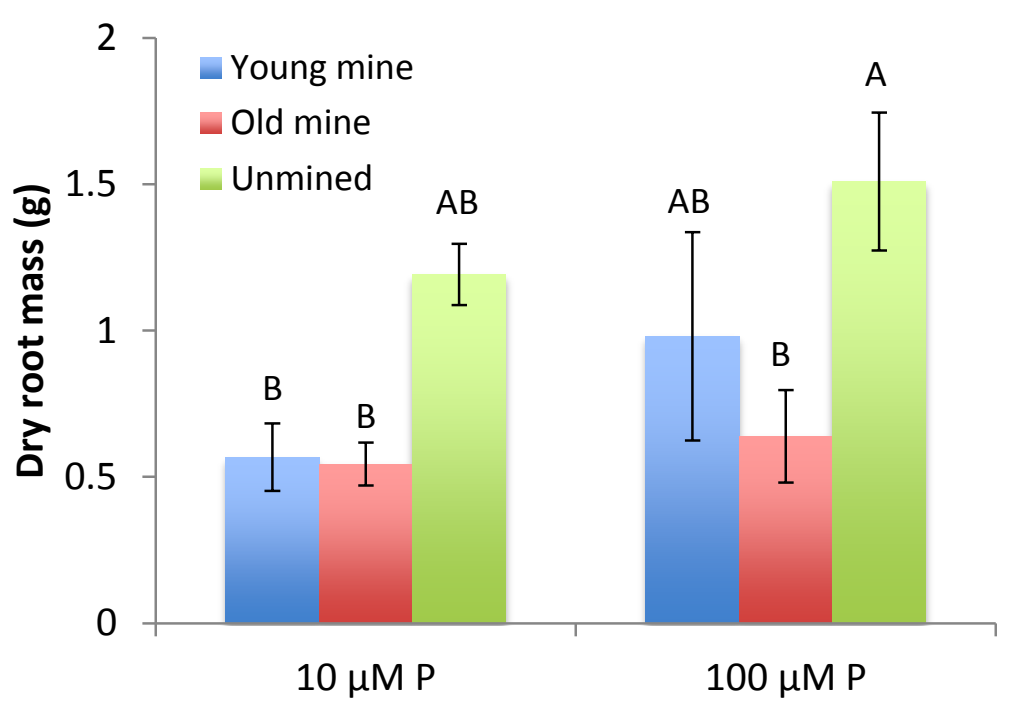

Figure 3.2. Shoot (a) and root (b) dry mass of red clover plants grown in sand culture with nutrient solution containing $10 \mu \mathrm{M}$ or $100 \mu \mathrm{M}$ phosphorus and inoculated with arbuscular mycorrhizal fungal communities from a five year-old reclaimed surface mine, an 18 year-old reclaimed surface mine, or an unmined hillside. Bars represent the mean of $4-6$ plants. Bars that don't share a letter are different by Tukey HSD $\alpha=0.05$. 


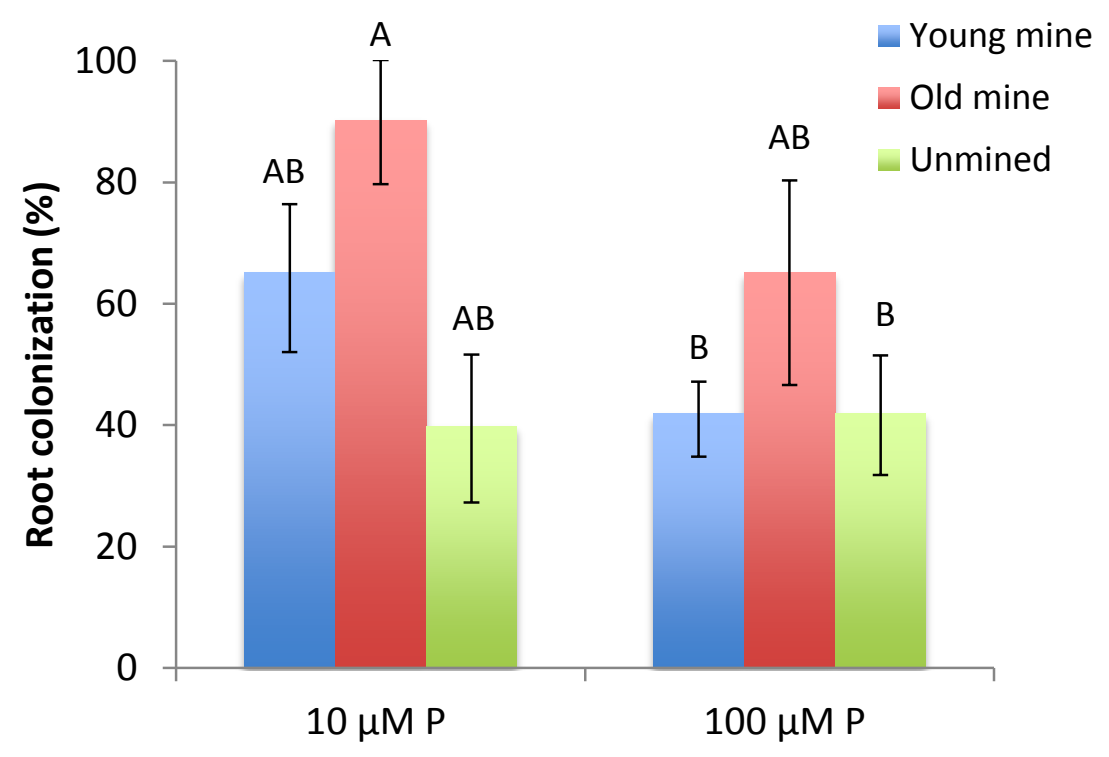

Figure 3.3. Extent of colonization by AMF of red clover roots grown in sand culture with nutrient solution containing $10 \mu \mathrm{M}$ or $100 \mu \mathrm{M}$ phosphorus and inoculated with arbuscular mycorrhizal fungal communities from a five year-old reclaimed surface mine, an 18 year-old reclaimed surface mine, or an unmined hillside. Bars represent the mean of $4-6$ plants. Bars that don't share a letter are different by Tukey HSD $\alpha=0.05$. Data were arcsine-transformed for ANOVA to meet normality assumptions and are presented here back-transformed.

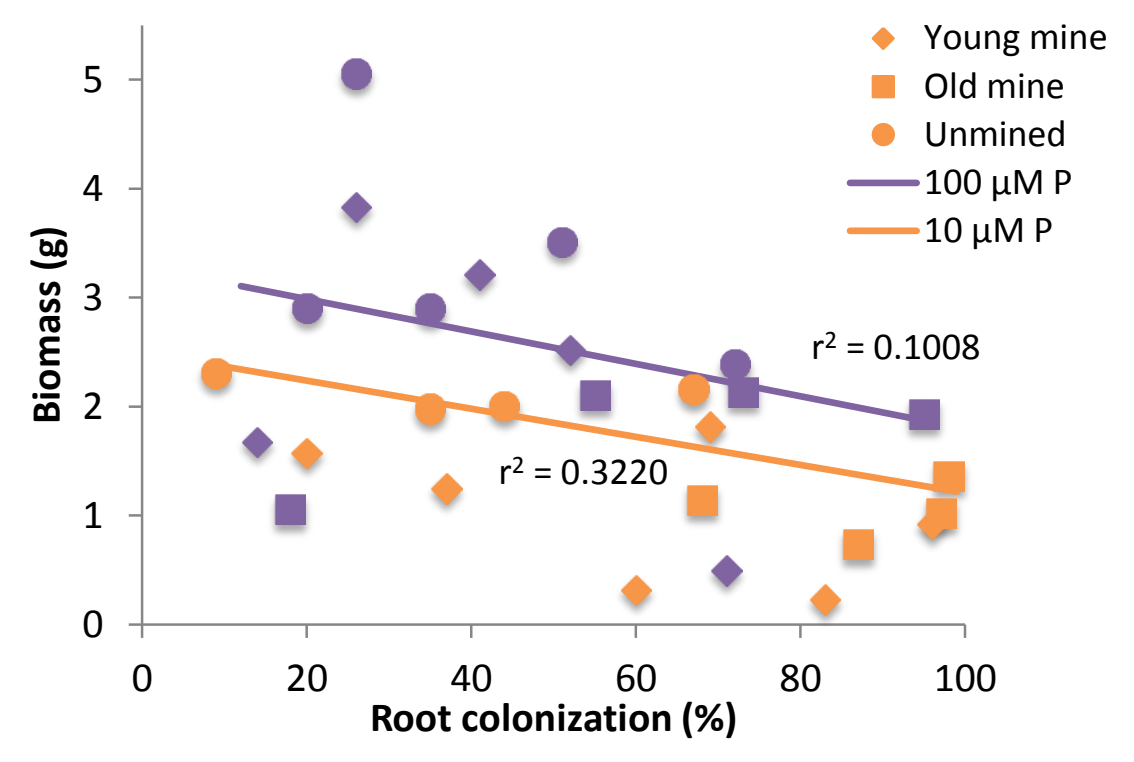

Figure 3.4. Total plant biomass vs. colonization of roots by AMF. Red clover plants were grown in sand culture with nutrient solution containing $10 \mu \mathrm{M}$ or $100 \mu \mathrm{M}$ phosphorus and inoculated with arbuscular mycorrhizal fungal communities from a five year-old reclaimed surface mine, an 18 year-old reclaimed surface mine, or an unmined hillside. 


\subsubsection{Plant efficiency}

Leaf-tissue $\mathrm{P}$ concentration of plants grown with $100 \mu \mathrm{M}$ P was $62 \%$ greater than that of plants grown with $10 \mu \mathrm{M}$ P (Figure 3.5; $\mathrm{p}<0.001$ ). Leaf-tissue $\mathrm{P}$ concentration also varied significantly with fungal inoculum $(p=0.044)$, with plants inoculated with AMF from the young mine having the highest concentration of tissue $P$ and plants inoculated with AMF from the unmined site having the least concentrated tissue $P$. This effect did not depend on $P$ treatment $(P \times$ inoculum effect $p=0.937)$.

Across all inocula, larger plants had lower leaf $P$ concentrations (Figure 3.6; $p<0.001$ ). This response was more pronounced in plants grown with $10 \mu \mathrm{M}$ P nutrient solution (P-treatment $\times$ leaf $P$ effect $p=0.028$ ).

Plant use index (PUI) - calculated as the ratio of total plant biomass to leaf $\mathrm{P}$ concentrationdid not vary between plants grown in 100 and $10 \mu \mathrm{M}$ P nutrient solutions (Table 3.2; $p=0.721$ ). However fungal inoculum had a strong effect on PUI $(p<0.001)$. This effect did not vary between $P$ treatments $(P \times$ inoculum effect $p=0.843)$.

Leaf chlorophyll concentration, as inferred from SPAD readings, was greater in plants grown with $100 \mu \mathrm{M}$ P than $10 \mu \mathrm{M}$ P (Figure 3.7; $\mathrm{p}<0.001$ ). Leaf chlorophyll concentration also varied among fungal inocula ( $p=0.006)$, with plants inoculated with AMF from the old mine having less chlorophyll than plants inoculated with either of the other fungal communities (by one-way Tukey HSD). The inocula effect was independent of nutrient-solution phosphorus level (interactive effect $p=0.295$ ).

The quantity of $\mathrm{P}$ that leached from pots of plants given $100 \mu \mathrm{M} \mathrm{P}$ was $78 \%$ greater than from those given $10 \mu \mathrm{M} P$ (Figure 3.8; $p=0.017$ ). The amount of $P$ leached did not differ among the various fungal inocula $(p=0.663)$; however, the difference in $P$ leached between $P$ treatments varied among fungal inocula (interactive effect $p=0.035$ ). 


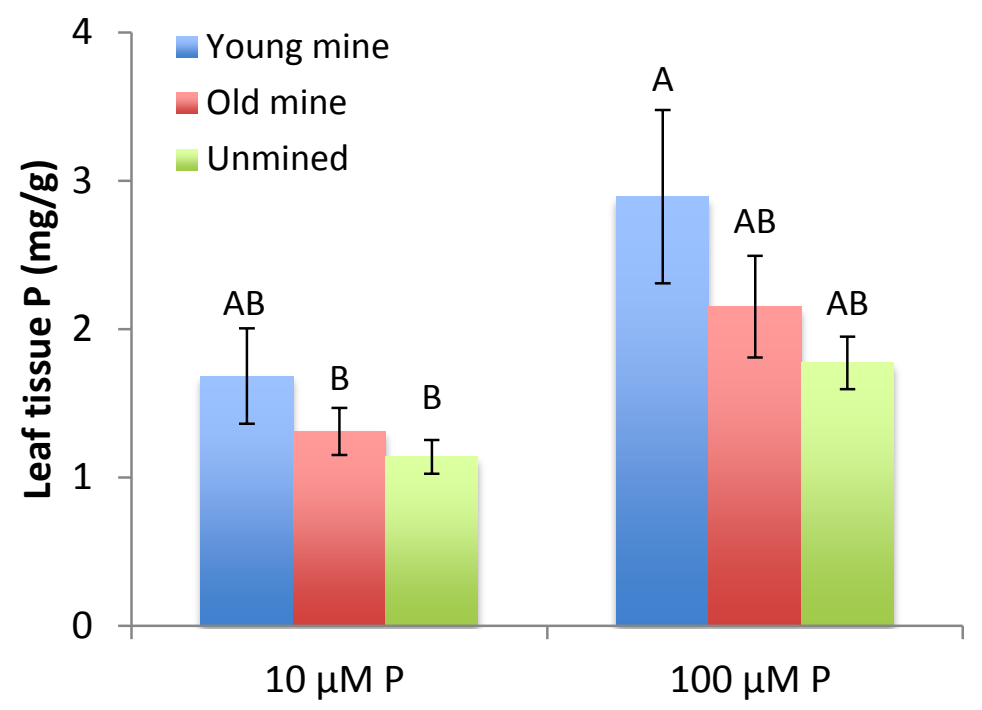

Figure 3.5. Leaf tissue $P$ concentration of red clover plants grown in sand culture with nutrient solution containing $10 \mu \mathrm{M}$ or $100 \mu \mathrm{M}$ phosphorus and inoculated with arbuscular mycorrhizal fungal communities from a five year-old reclaimed surface mine, an 18 year-old reclaimed surface mine, or an unmined hillside. Each bar represents the mean of $4-6$ plants, for which eight leaves were digested and analyzed for $\mathrm{P}$ content. Data were In-transformed for ANOVA to meet normality assumptions and are presented here back-transformed. Bars that do not share a letter are different by Tukey HSD $\alpha=0.05$.

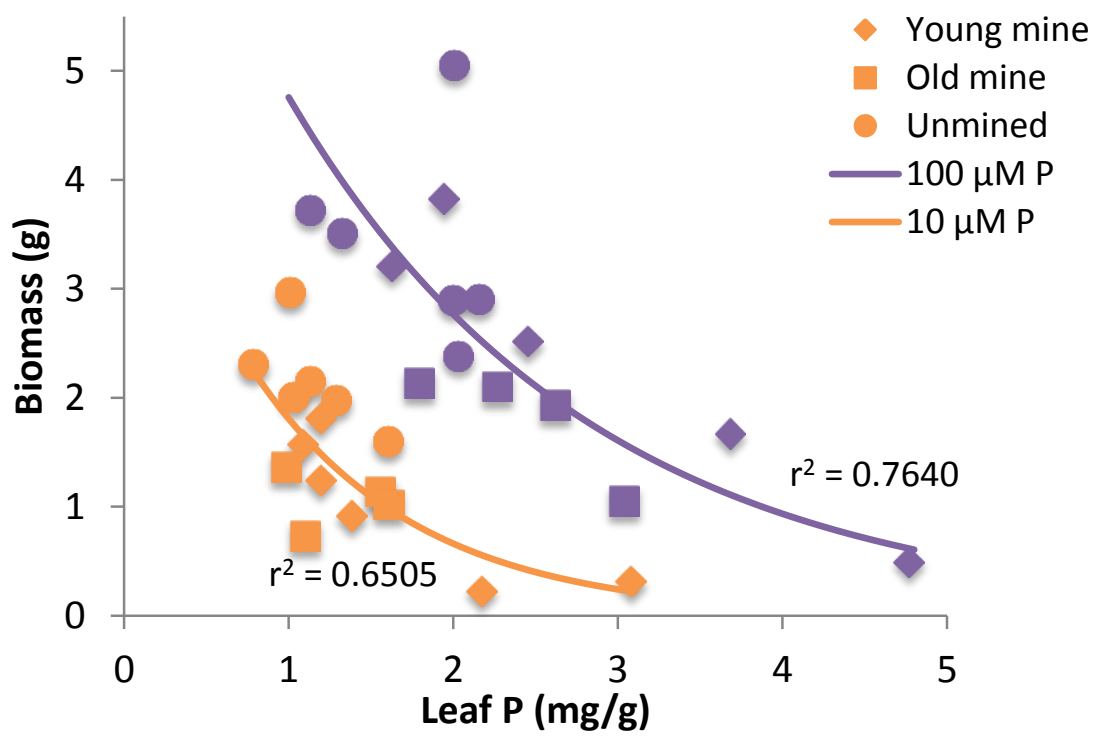

Figure 3.6. Biomass vs. tissue P. Red clover plants were grown in sand culture with nutrient solution containing $10 \mu \mathrm{M}$ or $100 \mu \mathrm{M}$ phosphorus and inoculated with arbuscular mycorrhizal fungal communities from a five year-old reclaimed surface mine, an 18 year-old reclaimed surface mine, or an unmined hillside. 
Table 3.2. Phosphorus use index (PUI).

\begin{tabular}{llc}
\hline \hline Treatment & Inoculum & PUI (g biomass / (mg P / g digested leaf)) \\
\hline $10 \mu \mathrm{M} \mathrm{P}$ & Young mine & $0.81 \pm 0.26^{\mathrm{a}}$ \\
& Old mine & $0.86 \pm 0.18^{\mathrm{ab}}$ \\
& Unmined & $2.05 \pm 0.32^{\mathrm{b}}$ \\
$100 \mu \mathrm{M} \mathrm{P}$ & Young mine & $1.11 \pm 0.38^{\mathrm{ab}}$ \\
& Old mine & $0.81 \pm 0.14^{\mathrm{ab}}$ \\
& Unmined & $2.08 \pm 0.35^{\mathrm{b}}$ \\
\hline
\end{tabular}

Note: Red clover plants were grown in sand culture with nutrient solution containing $10 \mu \mathrm{M}$ or $100 \mu \mathrm{M}$ phosphorus and inoculated with arbuscular mycorrhizal fungal communities from a five year-old reclaimed surface mine, an 18 year-old reclaimed surface mine, or an unmined hillside. Each value is the mean of $4-6$ plants \pm standard error. Values that don't share a letter are different by Tukey HSD $\alpha=0.05$.

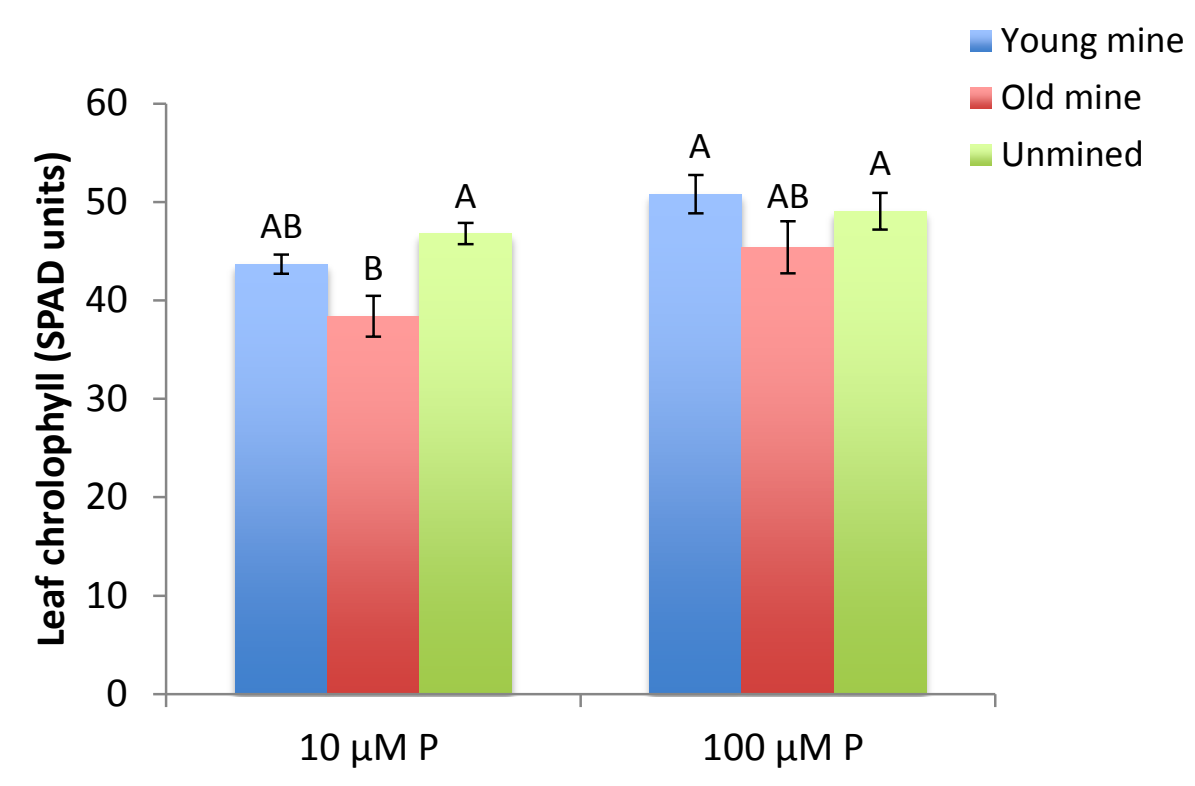

Figure 3.7. Chlorophyll content inferred from SPAD meter readings of red clover plants grown in sand culture with nutrient solution containing $10 \mu \mathrm{M}$ or $100 \mu \mathrm{M}$ phosphorus and inoculated with arbuscular mycorrhizal fungal communities from a five year-old reclaimed surface mine, an 18 year-old reclaimed surface mine, or an unmined hillside. Each bar represents the mean of $4-6$ plants, for which the chlorophyll content of each was assessed on 24 leaflets. Bars that do not share a letter are different by Tukey HSD $\alpha=0.05$. 


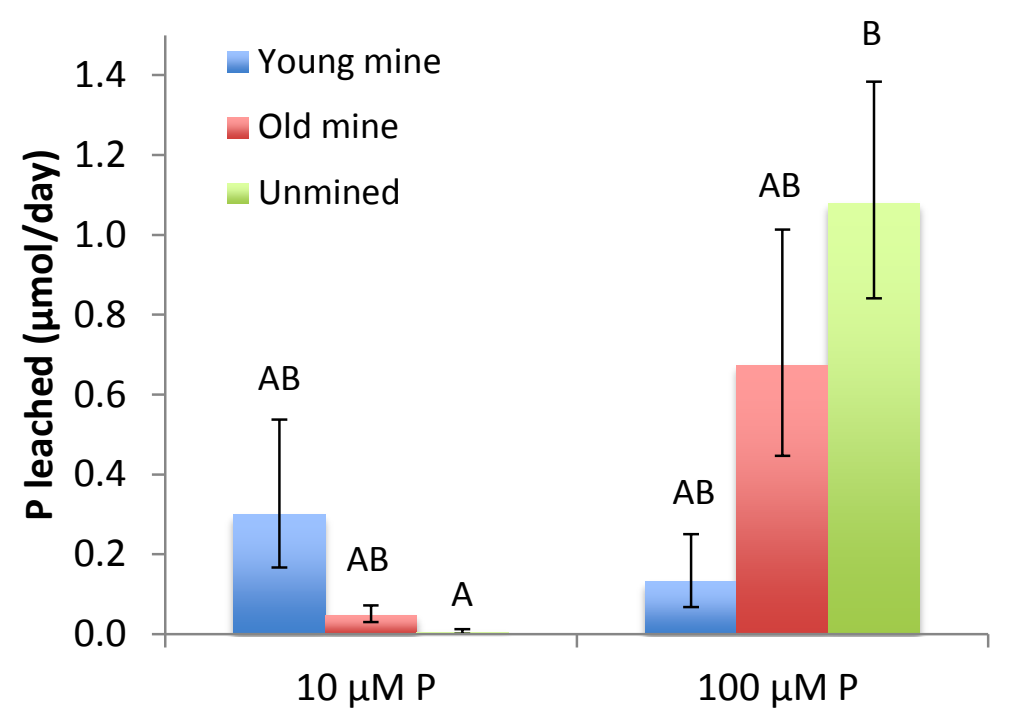

Figure 3.8. Phosphorus content of leachate from pots containing red clover grown in sand culture with nutrient solution containing $10 \mu \mathrm{M}$ or $100 \mu \mathrm{M}$ phosphorus and inoculated with arbuscular mycorrhizal fungal communities from a five year-old reclaimed surface mine, an 18 year-old reclaimed surface mine, or an unmined hillside. Each bar represents the mean of four collections made over the course of the experiment from each of two or three pots. Data were In-transformed to meet ANOVA assumptions and are presented here back-transformed. Bars that do not share a letter are different by Tukey HSD $\alpha=$ 0.05 .

\subsubsection{Plant stress response}

Acid phosphatase activity of roots was significantly greater for plants grown in $10 \mu \mathrm{M}$ versus $100 \mu \mathrm{M}$ P nutrient solution (Figure 3.9; $p=0.003$ ). The effect of inoculum on acid phosphatase activity was marginally significant $(p=0.066)$ and did not differ with $P$ treatment (interactive effect $p=0.658)$.

Across all inocula, APase activity was significantly negatively correlated with leaf-tissue $\mathrm{P}$ concentration (Figure 3.10; $p=0.024$ ). The relationship between APase activity and leaf $P$ concentration varied among the inocula sources (leaf $P \times$ inoculum effect $p=0.041$ ), with no significant relationship for plants inoculated with AMF from the young mine or old mine site ( $p$ $=0.816$ and 0.884 , respectively) but a strong relationship for plants inoculated with AMF from the unmined site $(p=0.018)$.

Root exudation of citrate did not differ between $\mathrm{P}$ treatments or among inocula (Figure 3.11a; P-treatment $p=0.783$; inocula $p=0.215)$. Root exudation of malate/malonate was greater 
among plants grown with $100 \mu \mathrm{M}$ P than $10 \mu \mathrm{M}$ P and did not differ among inocula (Figure 3.11b; P-treatment $p=0.007$; inocula $p=0.205)$. Root exudation of lactate was less among plants grown with $100 \mu \mathrm{M}$ P than $10 \mu \mathrm{M}$ P and did not differ among inocula (Figure 3.11c; Ptreatment $p=0.011$; inocula $p=0.379$ ).

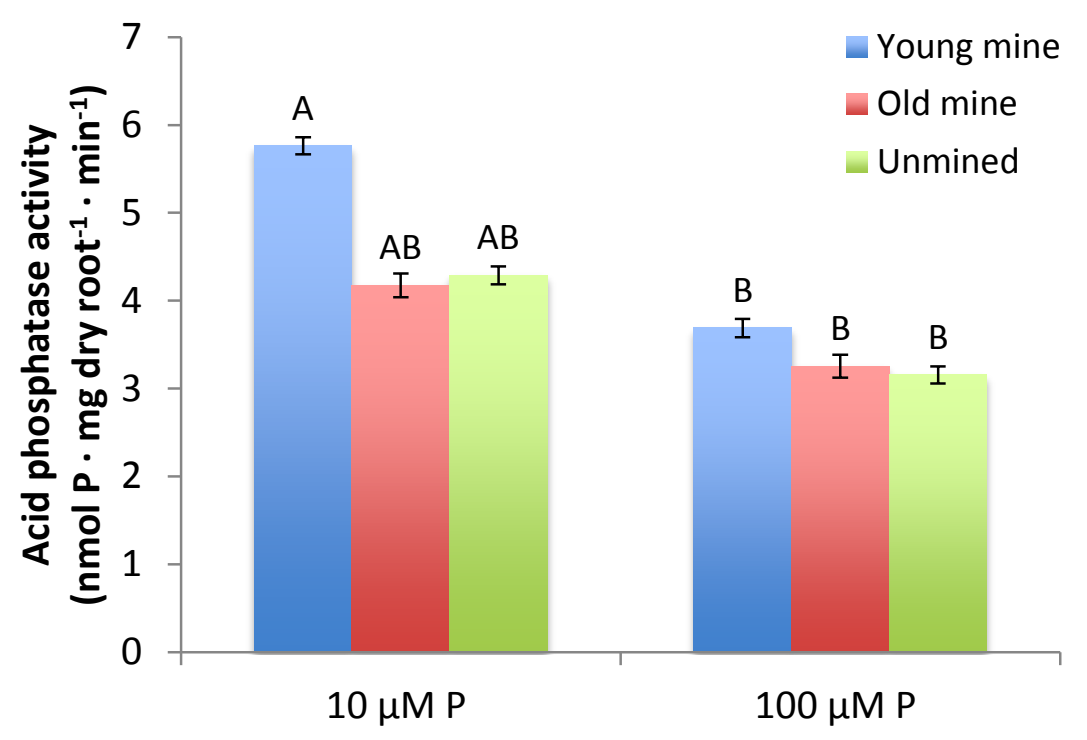

Figure 3.9. Acid phosphatase activity of red clover plants grown in sand culture with nutrient solution containing $10 \mu \mathrm{M}$ or $100 \mu \mathrm{M}$ phosphorus and inoculated with arbuscular mycorrhizal fungal communities from a five year-old reclaimed surface mine, an 18 year-old reclaimed surface mine, or an unmined hillside. Each bar represents the mean of $4-6$ plants, upon harvest of which $25 \mathrm{mg}$ (dry weight) of roots were assessed for ability to cleave P from para-nitrophenyl phosphate. Data were Intransformed for ANOVA to meet normality assumptions and are presented here back-transformed. Bars that do not share a letter are different by Tukey HSD $\alpha=0.05$. 


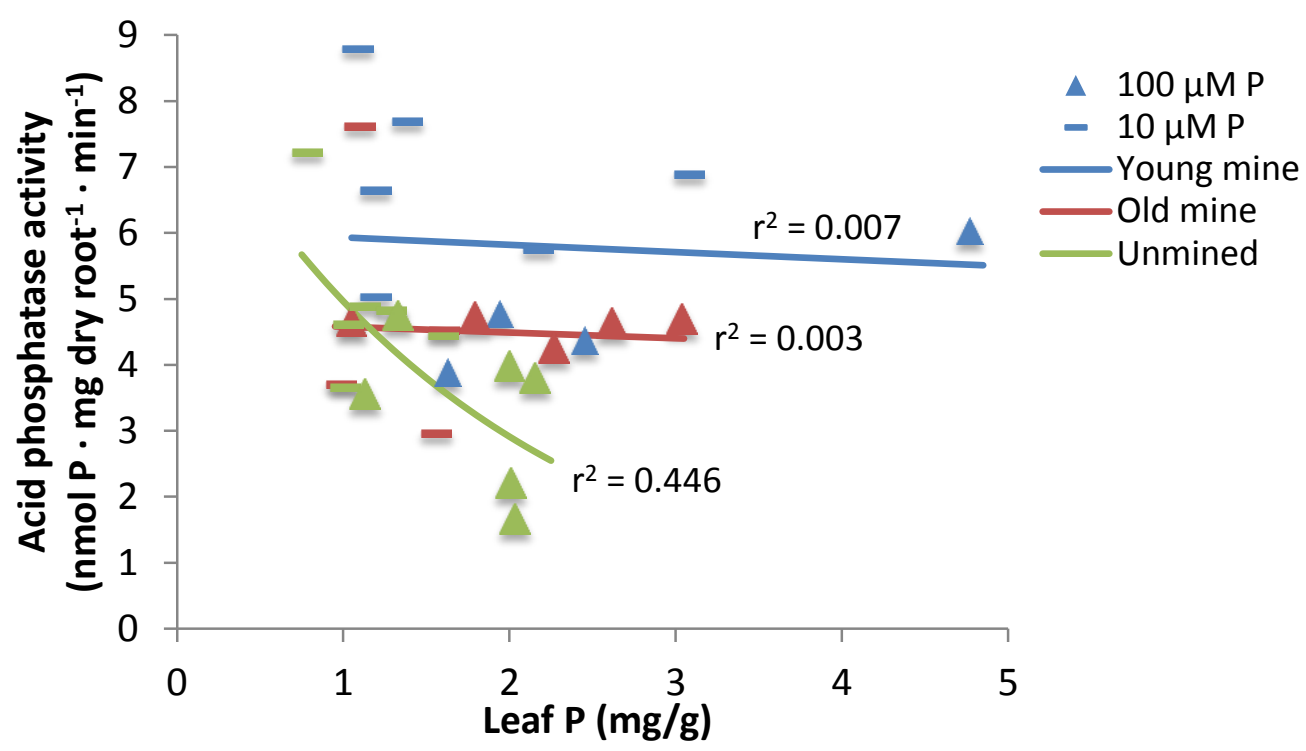

Figure 3.10. Acid phosphatase activity as a function of leaf-tissue $P$ concentration and fungal inoculum. Red clover plants were grown in sand culture with nutrient solution containing $10 \mu \mathrm{M}$ or $100 \mu \mathrm{M}$ phosphorus and inoculated with arbuscular mycorrhizal fungal communities from a five year-old reclaimed surface mine, an 18 year-old reclaimed surface mine, or an unmined hillside. 


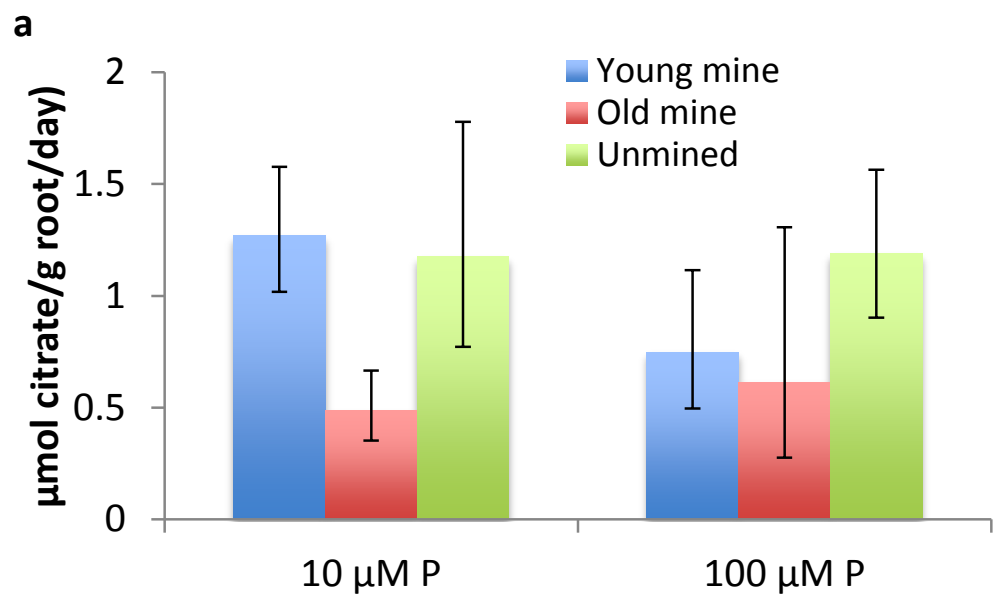

b

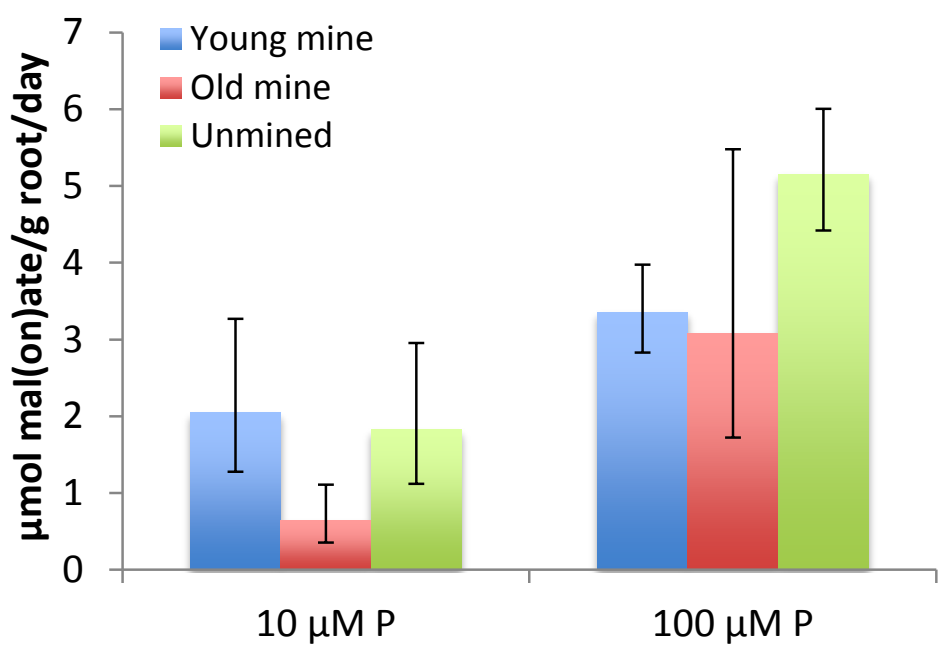

C

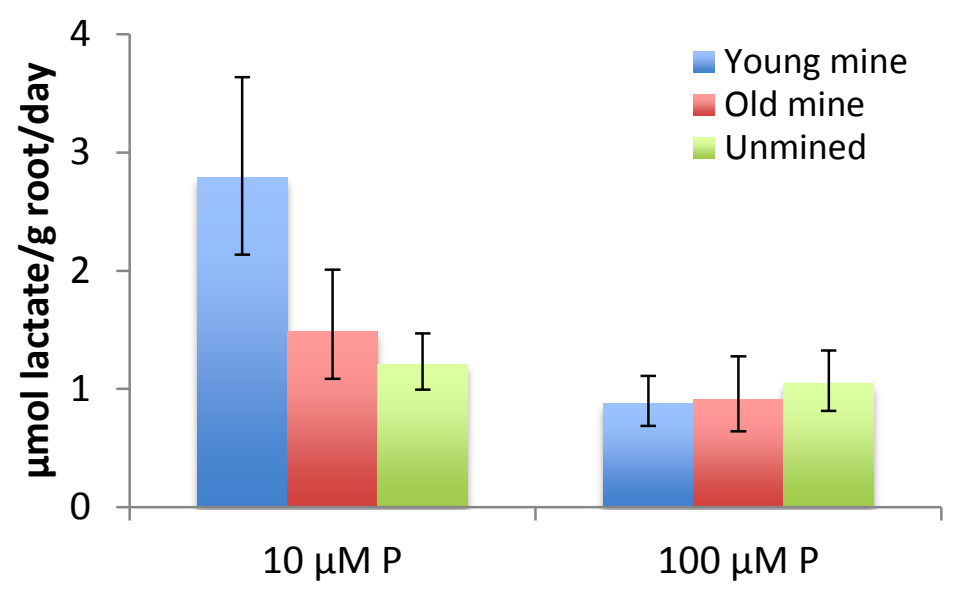

Figure 3.11. Exudation of citrate (a), malate and malonate, which were quantified together due to HPLC peaks being irresolvable (b), and lactate (c) by roots of red clover grown in sand culture with nutrient solution containing $10 \mu \mathrm{M}$ or $100 \mu \mathrm{M}$ phosphorus and inoculated with arbuscular mycorrhizal fungal communities from a five year-old reclaimed surface mine, an 18 year-old reclaimed surface mine, or an unmined hillside. Each bar represents the mean of 4-6 plants. Data were In-transformed to meet ANOVA assumptions and are presented here back-transformed. 


\subsection{Discussion}

Surface mining and reclamation to pasture have substantial impacts on ecosystem structure and function (Simmons and others 2008), including changes in microbial activity and diversity (Harris and others 1989) and AMF community composition and infectivity (Allen and Allen 1980; Frost and others 2001). In this study, we tested the ability of AMF communities from older and younger SMCRA-reclaimed surface mines and an unmined hillside to confer benefits to red clover (Trifolium pretense) host plants under conditions of high and low $\mathrm{P}$ availability.

\subsubsection{Plant response}

Clover inoculated with AMF from the unmined site had significantly larger roots and shoots than clover inoculated with AMF from either of the reclaimed mine sites (Figure 3.2), and this effect was independent of $P$ treatment. Clover inoculated with AMF from the old and young mines had similar root and shoot mass. These results suggest that the AMF from the PR sites were less beneficial for growth than AMF from the unmined site. These differences could reflect community- or species-level changes to AMF brought about by the mining and reclamation processes (Table 3.1). The influence of AMF on plant growth responses range from strongly negative to strongly positive, even within fungal taxa, plant taxa, and nutrient conditions (Klironomos 2003).

With regard to AMF from highly disturbed sites, Noyd and others (1995) found that the effect of inoculation with AMF from taconite iron ore tailings on grasses grown in tailings ranged from negative to positive depending on plant species and P-levels with few generalizable patterns. Similarly, Gryndler and others (2008) found that inoculation with AMF from coal mine sedimentation ponds and spoil banks could positively or negatively affect reed canarygrass biomass depending on how much organic matter was added to the clayey spoil material used as a growth medium. Thus, AMF from highly disturbed sites may be beneficial to some plants in some conditions and deleterious to other plants in the same or different conditions. In this study, plants inoculated with AMF from the undisturbed site were considerably larger than plants inoculated with AMF from either of the disturbed site regardless of P-treatment, and 
time since disturbance had no effect on biomass response of plants. These growth differences could reflect positive influence of AMF from the unmined site, negative influence of AMF from the PR sites, or both. Furthermore, they could be caused by changes at the AMF community, species, or population level, as functional efficacy varies widely among ecotypes and genotypes within AMF species (Kelly and others 2005; Klironomos 2003).

Roots of clover exposed to AMF from the old mine were nearly twice as colonized on a rootlength basis as clover exposed to AMF from the unmined site, with clover exposed to AMF from the young mine being intermediately colonized (Figure 3.3). Plants grown in $100 \mu \mathrm{M}$ were marginally less colonized than plants grown in $10 \mu \mathrm{M}$. These results contrast with those of (Allen and Allen 1980), who found colonization was reduced by roughly half several years after surface mining and reclamation, and our previous work (Levy in preparation), which found a steady increase in infectivity of AMF with time on reclaimed mines up to twelve years old. As with many aspects of the mycorrhizal symbiosis, many variables likely affect infectivity of fungal communities, and these results highlight the need to partition those sources of variance and broaden the conditions of testing to increase generalizability of the findings.

In the present study, decreased biomass was significantly associated with higher colonization (Figure 3.4). This effect was present across both P-treatments and all inocula. The relationship between fungal colonization and plant growth response is complex and depends on plant and fungal identity as well as growth conditions (Graham and Abbott 2000; Hetrick and others 1993). For example, Harner and others (2010) grew spotted knapweed in old and young riparian soils with AMF from the same old and young sites and found a significant negative correlation between knapweed biomass and colonization for both inocula in the young soil, but this correlation was absent in the old soil, regardless of inoculum. Hindrance of plant growth by AMF has traditionally been attributed to the carbon cost of supporting the fungi (Lynch and Ho 2005); however, it may also be related to changes in P dynamics (Smith and Smith 2011). For example, Nagy and others (2009) found that direct uptake of P by roots of non-mycorrhizal tomato exceeded the sum of direct and mycorrhizal uptake by tomato inoculated with Glomus 
intraradices. The present results indicate that time since disturbance does not drive the relationship between AMF colonization and plant growth.

\subsubsection{Plant efficiency}

Leaf tissue $\mathrm{P}$ of clover inoculated with fungi from the young mine was $57 \%$ greater than clover inoculated with fungi from the unmined site, and clover inoculated with fungi from the old mine were intermediate (Figure 3.5). This effect was independent of P-level (Inoculum $\times$ Ptreatment effect $p=0.9)$. However, high tissue $P$ did not translate into larger plants, even under the P-limiting treatment of $10 \mu \mathrm{M} \mathrm{P}$ nutrient solution. In fact, there was a significant negative relationship between leaf $\mathrm{P}$ concentration and plant biomass across all inocula, both at 10 and $100 \mu \mathrm{M} P$ (Figure 3.6). This suggests that plants that were able to make the most efficient use of acquired $\mathrm{P}$-as opposed to those that acquired the most $\mathrm{P}$-were the largest. Plants inoculated with AMF from the unmined site were 2.3-times more P-efficient than plants inoculated with AMF from the mined sites (Table 3.2). Phosphorus use index did not vary between 10 and $100 \mu \mathrm{M}$ P-treatments, either across or within inoculum sources, suggesting that plants didn't adjust their underlying phosphorus use strategies based on the availability of $\mathrm{P}$ in the growth medium.

The selection pressures acting on AMF during and after mining and reclamation are likely dominated by surviving the topsoil-stockpiling period and acquiring water for seeded or pioneering plants in highly compacted, low-moisture soil. Selection pressure (Helgason and Fitter 2009) for genes that aid P scavenging may be relaxed during and after PR by strong selection for genes that enable AMF to survive stockpiling and thrive under water stress, and relaxed even further on site where copious $\mathrm{P}$ fertilizer is applied (Appendix B). Thus, AMF populations and communities on PR sites may be better suited to aid plants under water stress, or other stresses present during and after mining and reclamation, but of less help to plants experiencing P stress. This concept supports our P-efficiency results, noted above.

Leaf chlorophyll concentration was significantly greater in plants grown in $100 \mu \mathrm{M}$ P than 10 $\mu \mathrm{M} P$ (Figure 3.7), and significantly less in clover inoculated with fungi from the old mine than 
either the young mine or unmined site. Clover form symbioses with nitrogen-fixing Rhizobia, and clover seeds in this experiment were inoculated with such. Nitrogen fixation is a highly Pdependent process and is often limited by P-availability (Schlesinger 1991). The lower leaf chlorophyll content of plants grown in $10 \mu \mathrm{M}$ P may reflect a lower level of $\mathrm{N}$-fixation caused by P-stress that lead to chlorophyll synthesis limitation. This mechanism could also be responsible for the lower levels of chlorophyll in clover inoculated with AMF from the old mine; however, those plants had no less leaf-P than young mine-AMF-inoculated clover, suggesting another mechanism may be at work. AMF can transfer $\mathrm{N}$ from the growth environment to plants (Mader and others 2000), and it has been reported that up to $20 \%$ of plant $\mathrm{N}$ can be acquired via AMF (Leigh and others 2009). Thus, old mine AMF may have been less efficient at capturing $\mathrm{N}$ from the growth environment than the other AMF communities. It is also possible that the greater colonization of roots by AMF from the old mine led to resource allocation away from $\mathrm{N}$ acquisition, leading to the observed lower leaf chlorophyll levels.

Significantly more $\mathrm{P}$ leached from pots given $100 \mu \mathrm{M}$ P than those given $10 \mu \mathrm{M}$ P; however, the difference was only $78 \%$, in contrast to the 10 -fold difference in $\mathrm{P}$ delivered. Thus, clover given $100 \mu \mathrm{M}$ P absorbed the vast majority of that P. While there were no significant differences in how much $\mathrm{P}$ leached from pots containing different inocula, there was a significant inoculum $\times$ P-treatment effect. Among pots given $10 \mu \mathrm{M}$ P, the most $\mathrm{P}$ leached from pots containing AMF from the young mine. In contrast, among pots given $100 \mu \mathrm{M}$ P, the most $\mathrm{P}$ leached from pots containing AMF from the unmined site (Figure 3.8). This different relationship of the various AMF communities to $P$ is consistent with the observation that plants inoculated with AMF from the unmined site were far more P-efficient than plants inoculated with AMF from the mined sites. Lynch and Ho (2005) adopted the language of economics to describe plant responses to P scarcity. Borrowing on that metaphor, plants inoculated with AMF from the unmined site were rational actors both under $\mathrm{P}$ scarcity and abundance. When $\mathrm{P}$ was abundant, they put less resources into acquiring it, allowing more $\mathrm{P}$ to leach from the $100 \mu \mathrm{M} \mathrm{P}$ pots. On the other hand, when $\mathrm{P}$ was scarce and likely limiting to growth, they put more resources into acquiring it, drawing down $\mathrm{P}$ concentrations from the $10 \mu \mathrm{M}$ P nutrient solution more than plants inoculated with AMF from either of the PR sites. 


\subsubsection{Plant stress response}

Acid phosphatase (APase) activity was significantly greater in plants grown with $10 \mu \mathrm{M}$ P versus $100 \mu \mathrm{M} P$ (Figure 3.9), reflecting the P-stressed status of plants in the low-P treatment. Plants inoculated with fungi from the young mine site had marginally greater APase activity than the other plants. Across all treatment conditions, APase activity was significantly negatively correlated with leaf $\mathrm{P}$ concentration (Figure 3.10), suggesting that plants that had amassed the least $P$ in their leaves were putting the most resources into acquiring $P$, either by augmenting root APase activity or by allocating more resources to AMF that elevated APase activity. However, when this correlation was partitioned among the three inocula, the relationship remained significant for the plants inoculated with AMF from the unmined site $\left(p=0.02 r^{2}=\right.$ $0.446)$, but not for either the young $\left(p=0.8, r^{2}=0.003\right)$ or old $\left(p=0.9, r^{2}=0.007\right)$ mine sites. Thus, APase may be constitutively active in plants inoculated with AMF from the mined sites but induced by $P$ stress in plants inoculated with AMF from the unmined site. Organic $P$ depletion in soil has sometimes (Tarafdar and Jungk 1987), but not always (Joner and Jakobsen 1995), been found to induce APase activity, and APase activity and inducability vary among AMF species and conditions (Joner and Johansen 2000).

We found no significant differences of exudation of any organic acid among inocula (Figure 3.11). Citrate production was unaffected by P-treatment; malate/malonate production was greater in $100 \mu \mathrm{M}$ P; and lactate production was greater in $10 \mu \mathrm{M} \mathrm{P}$. Organic acid production is a widely observed plant response to P-stress; however, it is not universal. For example, Neumann and Romheld (1999) found increased organic acid exudation under P-stress in chickpea and white lupin but not in tomato or wheat. There are no reports of differential organic acid production by red clover under $\mathrm{P}$ stress, despite this plant being a commonly used experimental organism. Together with our results, this suggests red clover may not respond to P stress by increasing organic acid production.

In conclusion, inoculation of red clover roots with the AMF community from an unmined site versus two pasture-reclaimed surface mines resulted in greater biomass likely as a consequence of more efficient use of $P$. There was less AMF species richness on the unmined site than the 
mined sites, but the unmined site contained two species that weren't present on either mined site. The functional differences among these communities of fungi could be related to functional gains from the species evidenced only on the unmined site, parasitism by the fungi found on the mined sites, or ecotypic differences between the fungi on different sites. Functional diversity among AMF is very high across communities, species, ecotypes, and genotypes (Kelly and others 2005; Munkvold and others 2004), and can vary substantially depending on plant host and local conditions (Klironomos 2003). Investigators that seek to examine the functionality of AMF on reclaimed mines must be cognizant of these sources of variance and the limits of generalizability and would do well to consider field studies to keep conditions as relevant to naturally-occurring mycorrhizal relationships as possible. 


\section{Evaluation of hypotheses and conclusions}

\subsection{Evaluation of hypotheses}

Study 1 - A chronosequence of surface mines reclaimed to pasture $0,3,7$, and 12 years ago and an unmined reference pasture were examined for soil properties, arbuscular mycorrhizal fungal infectivity and community, and plant community diversity and composition.

1) Soils

A) Physical soil properties

i) Soils will be severely compacted after mining, and little recovery of bulk density will be observed over twelve years.

Confirmed. Soil bulk density was 51\% greater on R0 than Pasture and unchanged among R0, R3, and R7. Some recovery was observed on R12 (27\% greater than Pasture), but bulk density was still significantly greater on the oldest site examined than the unmined pasture.

During site selection for the $2^{\text {nd }}$ experiment, bulk density was determined for three unmined sites and 12 PR surface mines ranging in age from four to 22 years (Appendix B). Bulk density was greater on all PR sites than any unmined site and showed no trend toward recovery with age on the PR sites.

ii) Water holding capacity will be severely reduced on recently reclaimed mines and will recover modestly over twelve years.

Mixed. WHC was $42 \%$ less on R0 than Pasture, but there was no signal of recovery: WHC of the PR sites of various ages did not differ significantly.

B) Chemical soil properties

i) Soil $\mathrm{pH}$ will be elevated immediately after reclamation and will return to natural, acidic levels by 12 years after reclamation.

Mixed. Soil pH of RO (4.6) was lower than any other site, mined or not, and was in the range of unamended soils of the region. Soil pH on R3 (7.2) was much higher than any other site. Soil pH on R7 (5.7), R12 (5.5), and Pasture (5.5) did not differ significantly, and while these soils are less acidic than the natural soils of the region, they are likely typical of managed pastures and appropriate for production of forage crops. 
ii) Soil $\mathrm{C}$ will be massively reduced on the youngest reclaimed mines and will accumulate over time.

Confirmed. Soil C was $1.2 \%$ of RO soil, versus $3.6 \%$ of Pasture soil and increased steadily with time to $3.3 \%$ on $\mathrm{R} 12$, reflecting the accumulation of soil organic matter over time after disturbance.

iii) Soil $\mathrm{N}$ will be high immediately after reclamation and will then decline over the first few years before accumulating thereafter.

Mixed. Soil $\mathrm{N}$ followed a pattern parallel to soil C, being $0.06 \%$ of R0 soil, $0.23 \%$ of R12 soil, and $0.28 \%$ of Pasture soil, again likely due to SOM accumulation. The hypothesis that soil $\mathrm{N}$ would be high immediately following mining was based on application of often large amounts of NPK fertilizer during reclamation, but this $\mathrm{N}$-spike on the young mines was absent, perhaps because the amount of $\mathrm{N}$ applied in fertilization is trivial relative to the amount in soil. Alternatively, no spike in soil K (table 1) was observed among the young mines either, so NPK fertilization may be less than was expected. The spike in soil $\mathrm{P}_{\mathrm{i}}$ is likely better explained by the application of rock phosphate than NPK fertilizer (discussed below).

iv) Inorganic phosphorus will be very high immediately after reclamation and will decline over time.

Rejected. Total inorganic $P$ was greatest on R3, likely as consequence of heavy rock-phosphate application, since $\mathrm{Ca}, \mathrm{Mg}$, and $\mathrm{pH}$-but not $\mathrm{N}$ or $\mathrm{K}$-were all greatest on $\mathrm{R} 3$. Total $\mathrm{P}_{\mathrm{i}}$ was not significantly different on any of the other sites; however, among the more easily accessible $\mathrm{P}_{\mathrm{i}}$ fractions, there were hints of accumulation with time since mining.

v) Organic phosphorus will follow an inverse pattern to inorganic $P$, being much reduced on the youngest mines and accumulating over time.

Confirmed, except in relation to the previous hypothesis. Both total $\mathrm{P}_{\mathrm{o}}$ and the more labile $\mathrm{P}_{\mathrm{o}}$ fractions were orders-of-magnitude less in the youngest mined sites and showed clear upward trends with time. With the exception of the most recalcitrant fraction, the amounts of $P_{0}$ in each extractant were not significantly different between R12 and Pasture.

2) Arbuscular mycorrhizal fungi

A) AMF inoculum potential will be drastically reduced on the young reclaimed sites and will recover over twelve years to approximately the same level as the unmined reference site. 
Confirmed. MIP was reduced by two-thirds on RO relative to Pasture, but showed steady increase with time and was only slightly less on R12 than Pasture.

B) AMF community

i) The community of AMF will be less diverse in the immediate aftermath of reclamation.

Confirmed. AMF species richness was significantly less on all but one (R7) of the reclaimed mine sites than the unmined site.

ii) The AMF community will become more diverse over a 12 year period but will not reach the diversity of the unmined reference site and much of this diversity gained over time will come from species not found on the unmined site.

Rejected. Species richness was greatest on Pasture and similar among the PR sites. Notably, only one AMF species was found on the reclaimed sites that was not also found on the unmined site. AMF community converged among the mine sites with Glomus species appearing to most resilient to the conditions during and after mining and reclamation.

3) Vegetation

A) Plant species diversity will be very low immediately following reclamation and will increase over time.

Confirmed. Far less plant diversity was found on the youngest PR sites than the unmined site. Species richness shows a pattern of (incomplete) recovery with time. Diversity measured by Shannon Index, which captures both richness and evenness, but was calculated from a smaller sample, also shows reduced diversity among the youngest sites and recovery with time.

B) However, the plant community on even the oldest PR sites will be significantly less diverse than the unmined reference site.

Confirmed. Species richness was still less than half on R12 than on Pasture. As measured by Shannon Index, plant diversity on R7 and R12 was not significantly different than Pasture.

C) A greater fraction of the community on all reclaimed mine sites will be made up of invasive species than the unmined site.

Mixed. No severely threatening invasive species were found on RO and less invasives of all categories were found on RO than any other site. Except for RO, however, total invasives and 
the most threatening invasives composed a greater fraction of the plant community on R3 than on any of the other sites, and, in general, on the mined sites than the unmined site.

Study 2 - Communities of arbuscular mycorrhizal fungi from an 18 year-old pasture-reclaimed surface mine (old mine), a five year-old pasture-reclaimed surface mine (young mine), and an unmined hillside (unmined site) were tested on red clover for their ability to confer benefits to their plant hosts under high and low phosphorus conditions.

1) Plant response

A) Plant biomass

i) Plants inoculated with AMF from the unmined site will be the largest and this difference will be pronounced for plants that receive $100 \mu \mathrm{M}$ P.

Mixed. Plants inoculated with AMF from the unmined site were indeed larger than plants inoculated with fungi from either of the mined site; however, this difference was not affected by P-treatment.

ii) Plants inoculated with fungi from the young mine will be the smallest independent of $\mathrm{P}$ treatment.

Unconfirmed. Biomass of plants inoculated with fungi from the two mines was not significantly different, regardless of P-treatment.

B) Colonization

i) Plants inoculated with fungi from the young mine will be the least colonized, and plants inoculated with fungi from the unmined site will be the most colonized.

Refuted. Colonization was greatest among the old mine site fungi and similar between the young mine and unmined site.

ii) There will be a direct relationship between colonization and plant biomass, and this relationship will be stronger for plants given $10 \mu \mathrm{M}$ P.

Refuted. There was an inverse relationship between colonization and biomass, and this relationship was not affected by P-treatment.

2) Plant efficiency 


\section{A) Leaf tissue $P$}

i) Tissue $P$ will be most concentrated in plants inoculated with fungi from the young mine and least concentrated in plant inoculated with fungi from the unmined site.

Mostly confirmed. Tissue $P$ was greatest among plants inoculated with fungi from the young mine and least among plants inoculated with fungi from the unmined site.

ii) There will be an inverse relationship between tissue $P$ and biomass, and this effect will be pronounced in plants given $10 \mu \mathrm{M}$ P.

Confirmed. Plants with greater biomass had lower tissue-P concentrations, and the slope of this relationship was steeper for plants given $10 \mu \mathrm{M}$ P than those given $100 \mu \mathrm{M}$ P.

iii) Phosphorus use index will be greatest for plants inoculated with AMF from the unmined site and least for plants inoculated with AMF from the young mine.

Half confirmed. Plants inoculated with fungi from the unmined site were far more efficient with their $P$ than plants inoculated with fungi from either mined site; however there was no difference between plants inoculated with fungi from the young and old mine sites.

B) Leaf chlorophyll

i) Leaf chlorophyll will be greater in plants given $100 \mu \mathrm{M}$ P than those given 10 $\mu \mathrm{M}$ P.

Confirmed.

ii) Leaf chlorophyll will be greatest in plants inoculated with AMF from the unmined site and least in plants inoculated with AMF from the young site.

Mixed. Leaf chlorophyll was not significantly different between plants inoculated with AMF from the young mine or unmined sites, but it was significantly less among plants inoculated with fungi from the old mine site.

C) Leachate $\mathrm{P}$ will be most concentrated from pots containing inoculum from the young mine and least concentrated from pots containing inoculum from the unmined site.

Unconfirmed. Leachate-P concentration did not differ among inocula sources; however, the inocula responded differently, in terms of amount of $P$ leached, to the P-treatments, with the 
unmined AMF leaching more $\mathrm{P}$ among the $100 \mu \mathrm{M}$ P pots and less among the $10 \mu \mathrm{M}$ P pots and vise-versa for the young mine site AMF.

3) Plant stress response

A) Acid phosphatase activity

i) Acid phosphatase activity will be greatest in plants inoculated with AMF from the young mine and least in plants inoculated with AMF from the unmined site, and this effect will be exasperated among plants given $10 \mu \mathrm{M}$ P.

Mostly unconfirmed. APase activity was marginally different among the various inocula sources, with plant inoculated with AMF from the young mine having the greatest activity, but the effect was independent of P-treatment.

ii) Acid phosphatase activity will be in inverse relationship to plant tissue $P$ concentration, and this effect will be most pronounced in plants inoculated with fungi from the unmined site.

Confirmed. Plants with the greatest leaf $\mathrm{P}$ concentration had the lowest APase activity, and this effect was strong among plants inoculated with fungi from the unmined site and nearly absent among plants inoculated with fungi from either of the mined sites.

B) Organic acid production will be greatest in plants with AMF from the young mine and least in plants inoculated with AMF from the unmined site, and this effect will be exasperated among plants given $10 \mu \mathrm{M}$ P.

Unconfirmed. Organic acid exudation did not differ among inocula, nor did it differ consistently among P-treatments.

\subsection{Conclusions}

We examined ecosystem structure on pasture-reclaimed (PR) surface mines in northern West Virginia between zero and 12 years old and mycorrhizal function on PR surface mines five and 18 years old and compared both to unmined sites. Mining and concurrent reclamation to pasture brought substantial changes to these ecosystems, some of which were partially or fully ameliorated over the short-to-medium term. Notably, soil chemistry was similar on the older PR sites and unmined reference. Soil physical properties, however, showed little evidence of recovery. AMF infectivity appears to recover rapidly. AMF communities were somewhat 
different between the PR and unmined sites examined (and among PR sites), but recovery of the full diversity of AMF communities on the unmined sites was not observed. Plant diversity was reduced on PR sites and showed slow and incomplete recovery toward the diversity and community composition observed on the unmined site. AMF from PR sites were less beneficial to their plant hosts than AMF from an unmined site. This effect appeared to be related to $\mathrm{P}$ utilization but was observed whether $\mathrm{P}$ was scarce or abundant. In conclusion, surface mining with concurrent reclamation to pasture brings broad and deep changes to ecosystem structure and function, some of which are partially or wholly ameliorated over the short-to-medium term. Changes to regulations that steer pasture reclamation toward less compaction of soil, seeding of more native and less invasive plants, and more measured use of lime and inorganic fertilizer could accelerate recovery and improve ecological structure and function on surface mined lands. 


\section{Appendix A. Plant communities of reclaimed mines of various ages.}

Table A.1. Plant species, their threat of invasion as classified by West Virginia Native Plant Society's Checklist of the Invasive Plant Species of West Virginia, and the number of plots on each site where they were observed.

\begin{tabular}{|c|c|c|c|c|c|c|}
\hline ID & Invasiveness threat & $\mathrm{RO}$ & R3 & $\mathrm{R7}$ & $\mathrm{R} 12$ & $\mathrm{P}$ \\
\hline Acer rubrum & $\mathrm{n} / \mathrm{a}$ & 0 & 1 & 2 & 1 & 0 \\
\hline Achillea millefolium & significant & 0 & 0 & 3 & 1 & 3 \\
\hline Allium cernuum & $\mathrm{n} / \mathrm{a}$ & 0 & 0 & 0 & 0 & 1 \\
\hline Ambrosia artemisifolia & $\mathrm{n} / \mathrm{a}$ & 3 & 0 & 1 & 0 & 0 \\
\hline Andropogon virginicus & $\mathrm{n} / \mathrm{a}$ & 0 & 0 & 0 & 3 & 3 \\
\hline Anthoxanthum odoratum & watch list & 0 & 0 & 1 & 3 & 3 \\
\hline Apocynum cannabinum & $\mathrm{n} / \mathrm{a}$ & 0 & 0 & 0 & 0 & 2 \\
\hline Arthraxon hispidus & severe & 0 & 0 & 0 & 0 & 1 \\
\hline Asclepias tuberosa & $\mathrm{n} / \mathrm{a}$ & 0 & 0 & 0 & 0 & 1 \\
\hline Aster pilosis & $\mathrm{n} / \mathrm{a}$ & 0 & 0 & 2 & 2 & 0 \\
\hline Aster puniceus & $\mathrm{n} / \mathrm{a}$ & 0 & 0 & 0 & 1 & 0 \\
\hline Aster sp. 1 & $\mathrm{n} / \mathrm{a}$ & 0 & 0 & 1 & 0 & 0 \\
\hline Aster sp. 2 & $\mathrm{n} / \mathrm{a}$ & 0 & 0 & 0 & 0 & 1 \\
\hline Aster sp. 3 & $\mathrm{n} / \mathrm{a}$ & 0 & 0 & 1 & 0 & 0 \\
\hline Aster sp. 4 & $\mathrm{n} / \mathrm{a}$ & 0 & 0 & 0 & 0 & 1 \\
\hline Aster sp. 5 & $\mathrm{n} / \mathrm{a}$ & 0 & 0 & 0 & 0 & 2 \\
\hline Asteraceae 1 & $\mathrm{n} / \mathrm{a}$ & 0 & 0 & 0 & 0 & 1 \\
\hline Asteraceae 2 & $\mathrm{n} / \mathrm{a}$ & 0 & 0 & 0 & 0 & 1 \\
\hline Asteraceae 3 & $\mathrm{n} / \mathrm{a}$ & 0 & 0 & 1 & 0 & 0 \\
\hline Asteraceae 4 & $\mathrm{n} / \mathrm{a}$ & 0 & 0 & 0 & 0 & 1 \\
\hline Avena sativa & $\mathrm{n} / \mathrm{a}$ & 3 & 0 & 0 & 0 & 0 \\
\hline Botrychium virginianum & $\mathrm{n} / \mathrm{a}$ & 0 & 0 & 0 & 0 & 1 \\
\hline Bromus inermis & severe & 0 & 3 & 0 & 1 & 0 \\
\hline Caprifoliaceae & $\mathrm{n} / \mathrm{a}$ & 0 & 0 & 0 & 0 & 1 \\
\hline Cirsium vulgare & significant & 0 & 0 & 1 & 0 & 1 \\
\hline Coronilla varia & severe & 0 & 0 & 3 & 1 & 1 \\
\hline Crataegus sp. & $\mathrm{n} / \mathrm{a}$ & 0 & 0 & 0 & 0 & 2 \\
\hline Dactylis glomerata & significant & 0 & 2 & 3 & 2 & 2 \\
\hline Daucus carota & lesser & 0 & 0 & 2 & 3 & 3 \\
\hline Digitaria ischaemum & $\mathrm{n} / \mathrm{a}$ & 3 & 0 & 0 & 0 & 0 \\
\hline Digitaria sangiunalis & $\mathrm{n} / \mathrm{a}$ & 0 & 0 & 0 & 0 & 1 \\
\hline Echinochloa crusn/agalli & $\mathrm{n} / \mathrm{a}$ & 2 & 0 & 0 & 0 & 0 \\
\hline Elaeagnus umbellata & severe & 0 & 0 & 0 & 0 & 1 \\
\hline Erechtites hieracifolia & $\mathrm{n} / \mathrm{a}$ & 1 & 0 & 0 & 0 & 0 \\
\hline Erigeron annuus & $\mathrm{n} / \mathrm{a}$ & 0 & 0 & 1 & 0 & 2 \\
\hline
\end{tabular}




\begin{tabular}{|c|c|c|c|c|c|}
\hline Festuca arundinacea & severe & 0 & 3 & 3 & 3 \\
\hline Galium concinnum & $\mathrm{n} / \mathrm{a}$ & 0 & 0 & 1 & 0 \\
\hline Galium pilosum & $\mathrm{n} / \mathrm{a}$ & 0 & 0 & 0 & 0 \\
\hline Hieracium gronovii & $\mathrm{n} / \mathrm{a}$ & 0 & 0 & 0 & 0 \\
\hline Hieracium pratense & significant & 0 & 0 & 0 & 3 \\
\hline Holcus lanatus & severe & 0 & 0 & 0 & 3 \\
\hline Hypochoeris radicata & $\mathrm{n} / \mathrm{a}$ & 0 & 0 & 0 & 0 \\
\hline Ipomoea pandurata & $\mathrm{n} / \mathrm{a}$ & 3 & 0 & 0 & 0 \\
\hline Lactuca scariola & watch list & 0 & 1 & 0 & 0 \\
\hline Leucanthemum vulgare & significant & 0 & 0 & 0 & 3 \\
\hline Liriodendron tulipifera & $\mathrm{n} / \mathrm{a}$ & 0 & 0 & 0 & 0 \\
\hline Lotus corniculatus & watch list & 0 & 3 & 3 & 3 \\
\hline Lysimachia quadrifolia & $\mathrm{n} / \mathrm{a}$ & 0 & 0 & 1 & 0 \\
\hline Medicago Iupulina & significant & 3 & 0 & 0 & 0 \\
\hline Medicago sativa & watch list & 0 & 2 & 0 & 0 \\
\hline Melilotus officianalis & significant & 0 & 2 & 0 & 1 \\
\hline Oxalis corniculata & $\mathrm{n} / \mathrm{a}$ & 0 & 0 & 0 & 0 \\
\hline Panicum clandestinum & $\mathrm{n} / \mathrm{a}$ & 0 & 0 & 2 & 1 \\
\hline Panicum implicatum & $\mathrm{n} / \mathrm{a}$ & 0 & 0 & 0 & 0 \\
\hline Phleum pratense & significant & 0 & 2 & 0 & 1 \\
\hline Plantago lanceolata & $\mathrm{n} / \mathrm{a}$ & 0 & 0 & 0 & 2 \\
\hline Plantago rugelii & $\mathrm{n} / \mathrm{a}$ & 0 & 0 & 0 & 1 \\
\hline Poa pretensis & severe & 0 & 2 & 3 & 1 \\
\hline Polygonum persicaria & significant & 3 & 0 & 0 & 0 \\
\hline Polygonum sp. & $\mathrm{n} / \mathrm{a}$ & 1 & 0 & 0 & 0 \\
\hline Potentilla cinquefoil & $\mathrm{n} / \mathrm{a}$ & 0 & 0 & 2 & 0 \\
\hline Potentilla simplex & $\mathrm{n} / \mathrm{a}$ & 0 & 0 & 0 & 1 \\
\hline Prunella vulgaris & $\mathrm{n} / \mathrm{a}$ & 0 & 0 & 0 & 3 \\
\hline Ranunculus sp. & $\mathrm{n} / \mathrm{a}$ & 0 & 0 & 0 & 0 \\
\hline Rhus radicans & $\mathrm{n} / \mathrm{a}$ & 0 & 0 & 0 & 0 \\
\hline Rosaceae sp. & $\mathrm{n} / \mathrm{a}$ & 0 & 0 & 0 & 0 \\
\hline Rubus sp. & $\mathrm{n} / \mathrm{a}$ & 0 & 0 & 2 & 1 \\
\hline Rudbeckia sp. & $\mathrm{n} / \mathrm{a}$ & 0 & 0 & 0 & 0 \\
\hline Rumex crispus & significant & 0 & 0 & 1 & 0 \\
\hline Salvia lyrata & $\mathrm{n} / \mathrm{a}$ & 0 & 0 & 0 & 0 \\
\hline Satureja vulgaris & $\mathrm{n} / \mathrm{a}$ & 0 & 0 & 3 & 3 \\
\hline Scarbrous aster & $\mathrm{n} / \mathrm{a}$ & 0 & 0 & 0 & 0 \\
\hline Scutellaria integrifolia & $\mathrm{n} / \mathrm{a}$ & 0 & 0 & 0 & 0 \\
\hline Senecio obovatus & $\mathrm{n} / \mathrm{a}$ & 0 & 0 & 1 & 1 \\
\hline Sisyrinchium angustifolium & $\mathrm{n} / \mathrm{a}$ & 0 & 0 & 0 & 0 \\
\hline Solanum carolinense & $\mathrm{n} / \mathrm{a}$ & 0 & 0 & 0 & 1 \\
\hline Solidago juncea & $\mathrm{n} / \mathrm{a}$ & 0 & 0 & 3 & 1 \\
\hline Solidago rugosa & $\mathrm{n} / \mathrm{a}$ & 0 & 0 & 1 & 0 \\
\hline
\end{tabular}




$\begin{array}{lllllll}\text { Solidago sp. } 1 & \text { n/a } & 0 & 0 & 0 & 0 & 2 \\ \text { Solidago sp. } 2 & \text { n/a } & 0 & 0 & 0 & 0 & 1 \\ \text { Taraxacum officinale } & \text { n/a } & 0 & 0 & 1 & 0 & 1 \\ \text { Trifolium agrarium } & \text { significant } & 0 & 0 & 0 & 1 & 1 \\ \text { Trifolium hybridum } & \text { significant } & 0 & 1 & 0 & 1 & 1 \\ \text { Trifolium pretense } & \text { lesser } & 3 & 3 & 3 & 3 & 3 \\ \text { Trifolium repens } & \text { significant } & 0 & 1 & 1 & 2 & 3 \\ \text { Triodia flava } & \text { n/a } & 0 & 0 & 0 & 1 & 2 \\ \text { Veronica officinalis } & \text { significant } & 0 & 0 & 0 & 0 & 2 \\ \text { Viola sp. 1 } & \text { n/a } & 0 & 0 & 0 & 0 & 3 \\ \text { Viola sp. } 2 & \text { n/a } & 0 & 0 & 0 & 0 & 1\end{array}$

Note: R0 is a surface mine reclaimed zero years ago, etc., and Pasture is an unmined pasture. For each of three plots on each site, species were identified in a $10 \mathrm{~m}^{2}$ area in late-June/early-July and in three $0.25 \mathrm{~m}^{2}$ quadrats in lateAugust/early-September, 2010. 


\section{Appendix B. Soils of pasture reclaimed surface mines and unmined pastures near Morgantown, WV}

Table B.1. Site information and soil chemistry. Highlighted rows represent sites selected for further analysis.

\begin{tabular}{|c|c|c|c|c|c|c|}
\hline WVDEP permit \# & Years since mining & Bulk density $\left(\mathrm{g} / \mathrm{cm}^{3}\right)$ & $\mathrm{pH}$ & $\mathrm{C}(\%)$ & $\mathrm{N}(\%)$ & Extractable $\mathrm{P}_{\mathrm{i}}(\mathrm{mg} / \mathrm{kg})$ \\
\hline S201004 & 4 & 1.043 & 7.37 & 0.99 & 1.19 & 96.5 \\
\hline S200801 & 4.8 & 1.049 & 5.98 & 1.61 & 1.44 & 20.8 \\
\hline S201001 & 6.5 & 1.045 & 6.08 & 1.07 & 0.99 & 179.8 \\
\hline S100698 & 10.7 & 0.915 & 6.15 & 2.11 & 1.85 & 85.2 \\
\hline S100297 & 11.4 & 1.061 & 5.71 & 1.44 & 1.29 & 52.4 \\
\hline S103190 & 12.3 & 1.048 & 6.14 & 2.11 & 1.78 & 148.3 \\
\hline S100895 & 13.4 & 0.945 & 4.89 & 2.63 & 1.72 & 37.6 \\
\hline S103390 & 16.5 & 0.936 & 5.25 & 2.51 & 2.29 & 104.2 \\
\hline S001780 & 18 & 0.977 & 5.83 & 2.24 & 1.42 & 24.4 \\
\hline S103891 & 18.1 & 1.036 & 7.02 & 1.23 & 1.27 & 98.4 \\
\hline S008080 & 18.4 & 1.015 & 4.46 & 1.43 & 1.28 & 91.3 \\
\hline S002382 & 21.6 & 1.048 & 6.7 & 2.23 & 1.89 & 21.7 \\
\hline $\mathrm{n} / \mathrm{a}$ & unmined & 0.829 & 5.42 & 3.44 & 2.71 & 11.0 \\
\hline $\mathrm{n} / \mathrm{a}$ & unmined & 0.813 & 7.17 & 3.20 & 2.80 & 15.1 \\
\hline
\end{tabular}

Note: All sites are within five miles west of Morgantown, WV. Soil to $10 \mathrm{~cm}$ depth near the base of 10 red clover (Trifolium pretense) plants was collected from each site. Site age was estimated using permit records and satellite imagery. Bulk density was measured by extracting a $10 \times 7.5 \mathrm{~cm}$ core, measuring the volume of the void with sand and weighing the core after drying at $65^{\circ} \mathrm{C}$. pH was measured in a 1:2.5 soil:water slurry. Soil $\mathrm{C}$ and $\mathrm{N}$ were measured using a Carlo Erba elemental analyzer. Soil $\mathrm{P}_{\mathrm{i}}$ was extracted with Mehlich 3 extractant and measured using molybdate spectrophotometry. 


\section{References}

Abdul-Kareem A and McRae S. 1984. The effects on topsoil of long-term storage in stockpiles. Plant and Soil 76(1):357-63.

Allen EB and Allen MF. 1980. Natural re-establishment of vesicular-arbuscular mycorrhizae following stripmine reclamation in Wyoming. J Appl Ecol 17(1):139-47.

Arriagada CA, Herrera MA, Ocampo JA. 2007. Beneficial effect of saprobe and arbuscular mycorrhizal fungi on growth of Eucalyptus globulus co-cultured with Glycine max in soil contaminated with heavy metals. J Environ Manage 84(1):93-9.

Ashby WC. 1998. Reclamation with trees pre- and post-SMCRA in Southern Illinois. International Journal of Surface Mining, Reclamation and Environment 12(3):117.

Augé RM. 2001. Water relations, drought and vesicular-arbuscular mycorrhizal symbiosis. Mycorrhiza 11(1):3-42.

Bell JC, Daniels WL, Zipper CE. 1989. The practice of "approximate original contour" in the Central Appalachians. I. Slope stability and erosion potential. Landscape Urban Plann 18(2):127-38.

Bever JD. 2002. Host-specificity of AM fungal population growth rates can generate feedback on plant growth. Plant Soil 244(1-2):281-90.

Brady NC and Weil RR. 2007. The nature and properties of soils. 14th ed. Upper Saddle River, NJ: Prentice Hall.

Brenner FJ, Werner M, Pike J. 1984. Ecosystem development and natural succession in surface coal mine reclamation. Environmental Geochemistry and Health 6(1):10-22.

Brown DG, Johnson KM, Loveland TR, Theobald DM. 2005. Rural land-use trends in the conterminous United States, 1950-2000. Ecol Appl 15(6):1851-63.

Buondonno A, Coppola E, Felleca D, Violante P. 1992. Comparing tests for soil fertility. I. Conversion equations between Olsen and Mehlich-3 as phosphorus extractants for 120 soils of South Italy. Commun Soil Sci Plant Anal 23(7-8):699-716.

Chaney WR, Pope PE, Byrnes WR. 1995. Tree survival and growth on land reclaimed in accord with public law 95-87. J Environ Qual 24(4):630-4.

Crutzen PJ and Stoermer EF. 2000. The "Anthropocene". International Geosphere-Biosphere Programme: 17-18. 
Cumming JR and Kelly CN. 2007. Pinus virginiana invasion influences soils and arbuscular mycorrhizae of a serpentine grassland. The Journal of the Torrey Botanical Society 134(1):63-73.

Cumming JR and Ning J. 2003. Arbuscular mycorrhizal fungi enhance aluminium resistance of broomsedge (Andropogon virginicus L.). Journal of Experimental Botany 54(386):1447-59.

Danalatos NG, Kosmas CS, Driessen PM, Yassoglou N. 1994. Estimation of the draining soil moisture characteristic from standard data as recorded in routine soil surveys. Geoderma 64(1-2):155-65.

Dueck TA, Visser P, Ernst WHO, Schat H. 1986. Vesicular-arbuscular mycorrhizae decrease zinctoxicity to grasses growing in zinc-polluted soil. Soil Biol Biochem 18(3):331-3.

Egerton-Warburton LM, Johnson NC, Allen EB. 2007. Mycorrhizal community dynamics following nitrogen fertilization: A cross-site test in five grasslands. Ecol Monogr 77(4):52744.

Ehinger M, Koch AM, Sanders IR. 2009. Changes in arbuscular mycorrhizal fungal phenotypes and genotypes in response to plant species identity and phosphorus concentration. New Phytol 184(2):412-23.

Entry JA, Rygiewicz PT, Watrud LS, Donnelly PK. 2002. Influence of adverse soil conditions on the formation and function of arbuscular mycorrhizas. Adv Environ Res 7(1):123-38.

Fresquez PR, Aldon EF, Lindemann WC. 1986. Microbial re-establishment and the diversity of fungal genera in reclaimed coal mine spoils and soils. Reclam Reveg Res 4(3):245-58.

Frost SM, StahI PD, Williams SE. 2001. Long-term reestablishment of arbuscular mycorrhizal fungi in a drastically disturbed semiarid surface mine soil. Arid Land Research and Management 15(1):3.

Gildon A and Tinker PB. 1983. Interactions of vesicular-arbuscular mycorrhizal infection and heavy metals in plants. New Phytol 95(2):247-61.

Giovannetti M and Mosse B. 1980. An evaluation of techniques for measuring vesicular arbuscular mycorrhizal infection in roots. New Phytol 84(3):489-500.

Gould AB and Liberta AE. 1981. Effects of topsoil storage during surface mining on the viability of vesicular-arbuscular mycorrhiza. Mycologia 73(5):914-22.

Graham JH and Abbott LK. 2000. Wheat responses to aggressive and non-aggressive arbuscular mycorrhizal fungi. Plant Soil 220(1-2):207-18.

Grime JP, Mackey JML, Hillier SH, Read DJ. 1987. Floristic diversity in a model system using experimental microcosms. Nature 328(6129):420-2. 
Gryndler M, Larsen J, Hršelová H, Řezáčová V, Gryndlerová H, Kubát J. 2006. Organic and mineral fertilization, respectively, increase and decrease the development of external mycelium of arbuscular mycorrhizal fungi in a long-term field experiment. Mycorrhiza 16(3):159-66.

Gryndler M, Sudova R, Pueschel D, Rydlova J, Janouskova M, Vosatka M. 2008. Cultivation of high-biomass crops on coal mine spoil banks: Can microbial inoculation compensate for high doses of organic matter? Bioresour Technol 99(14):6391-9.

Haering KC, Daniels WL, Galbraith JM. 2004. Appalachian mine soil morphology and properties: Effects of weathering and mining method. Soil Sci Soc Am J 68(4):1315-25.

Harner MJ, Mummey DL, Stanford JA, Rillig MC. 2010. Arbuscular mycorrhizal fungi enhance spotted knapweed growth across a riparian chronosequence. Biol Invasions 12(6):1481-90.

Harris JA, Birch P, Short KC. 1989. Changes in the microbial community and physicochemical characteristics of topsoils stockpiled during opencast mining. Soil use Manage 5(4):161-8.

Hartnett DC and Wilson GWT. 1999. Mycorrhizae influence plant community structure and diversity in tallgrass prairie. Ecology 80(4):1187-95.

Havlin JL, Beaton JD, Tisdale SL, Nelson WL. 2005. Soil fertility and fertilizers: An introduction to nutrient management. 7th ed. Upper Saddle River, NJ: Prentice Hall.

He Z and Honeycutt CW. 2005. A modified molybdenum blue method for orthophosphate determination suitable for investigating enzymatic hydrolysis of organic phosphates. Communications in Soil Science and Plant Analysis 36(9-10):1383.

Helgason T and Fitter AH. 2009. Natural selection and the evolutionary ecology of the arbuscular mycorrhizal fungi (phylum Glomeromycota). J Exp Bot 60(9):2465-80.

Hetrick BAD, Wilson GWT, Cox TS. 1993. Mycorrhizal dependence of modern wheat cultivars and ancestors - a synthesis. Canadian Journal of Botany-Revue Canadienne De Botanique 71(3):512-8.

Holl KD. 2002. Long-term vegetation recovery on reclaimed coal surface mines in the eastern USA. J Appl Ecol 39(6):960-70.

Indorante SJ, Jansen IJ, Boast CW. 1981. Surface mining and reclamation: Initial changes in soil character. J Soil Water Conserv 36(6):347-51.

Johnson CM, Stout PR, Broyer TC, Carlton AB. 1957. Comparative chlorine requirements of different plant species. Plant and Soil 8(4):337-53.

Johnson D, Vandenkoornhuyse PJ, Leake JR, Gilbert L, Booth RE, Grime JP, Young JP, Read DJ. 2004. Plant communities affect arbuscular mycorrhizal fungal diversity and community composition in grassland microcosms. New Phytol 161(2):503-15. 
Johnson NC, Wilson GWT, Bowker MA, Wilson JA, Miller RM. 2010. Resource limitation is a driver of local adaptation in mycorrhizal symbioses. Proceedings of the National Academy of Sciences 107(5):2093-8.

Joner EJ and Johansen A. 2000. Phosphatase activity of external hyphae of two arbuscular mycorrhizal fungi. Mycol Res 104:81-6.

Joner E and Jakobsen I. 1995. Growth and extracellular phosphatase-activity of arbuscular mycorrhizal hyphae as influenced by soil organic-matter rid F-1116-2011. Soil Biol Biochem 27(9):1153-9.

Jones JB Jr and Case VW. 1990. Sampling handling and analyzing plant tissue samples. In: Soil testing and plant analysis. Westerman RL, editor. 3rd ed. Madison, Wisc: Soil Science Society of America. 389-428.

Kelly CN, Morton JB, Cumming JR. 2005. Variation in aluminum resistance among arbuscular mycorrhizal fungi. Mycorrhiza 15(3):193-201.

Klironomos JN. 2003. Variation in plant response to native and exotic arbuscular mycorrhizal fungi. Ecology 84(9):2292-301.

Leigh J, Hodge A, Fitter AH. 2009. Arbuscular mycorrhizal fungi can transfer substantial amounts of nitrogen to their host plant from organic material. New Phytol 181(1):199-207.

Leyval C, Singh BR, Joner EJ. 1995. Occurrence and infectivity of arbuscular mycorrhizal fungi in some Norwegian soils influenced by heavy metals and soil properties. Water, Air, \& Soil Pollution 84(3):203-16.

Luscombe PC, Syers JK, Gregg PEH. 1979. Water extraction as a soil-testing procedure for phosphate. Commun Soil Sci Plant Anal 10(11):1361-9.

Lux HB and Cumming JR. 2001. Mycorrhizae confer aluminum resistance to tulip-poplar seedlings. Canadian Journal of Forest Research 31(4):694-702.

Lynch JP and Ho MD. 2005. Rhizoeconomics: Carbon costs of phosphorus acquisition. Plant Soil 269(1-2):45-56.

Mader P, Vierheilig H, Streitwolf-Engel R, Boller T, Frey B, Christie P, Wiemken A. 2000. Transport of $\mathrm{N}-15$ from a soil compartment separated by a polytetrafluoroethylene membrane to plant roots via the hyphae of arbuscular mycorrhizal fungi. New Phytol 146(1):155-61.

Marschner H. 1995. Mineral nutrition of higher plants, second edition. San Diego, CA: Academic Press.

McElfish JM and Daniels WL. 1990. Environmental regulation of coal mining, SMCRA's second decade. Washington, D.C.: Environmental Law Institute. 
Mehlich AA. 1984. Mehlich 3 soil test extractant: A modification of Mehlich 2 extractant. Commun Soil Sci Plant Anal 15(12):1409-16.

Mehrotra VS. 1998. Arbuscular mycorrhizal associations of plants colonizing coal mine spoil in India. The Journal of Agricultural Science 130(02):125.

Miller EK and Friedland AJ. 1994. Lead migration in forest soils - response to changing atmospheric inputs. Environ Sci Technol 28(4):662-9.

Miransari M. 2010. Contribution of arbuscular mycorrhizal symbiosis to plant growth under different types of soil stress. Plant Biology 12(4):563-9.

Moorman T and Reeves FB. 1979. The role of endomycorrhizae in revegetation practices in the semi-arid west. II. A bioassay to determine the effect of land disturbance on endomycorrhizal populations. Am J Bot 66(1):14-8.

Morton JB. 1993. Germ plasm in the international collection of arbuscular and vesiculararbuscular mycorrhizal fungi (INVAM) and procedures for culture development, documentation and storage. Mycotaxon 48:491-528.

Mummey DL and Rillig MC. 2006. The invasive plant species Centaurea maculosa alters arbuscular mycorrhizal fungal communities in the field. Plant Soil 288(1-2):81-90.

Munkvold L, Kjoller R, Vestberg M, Rosendahl S, Jakobsen I. 2004. High functional diversity within species of arbuscular mycorrhizal fungi. New Phytol 164(2):357-64.

Myster RW. 1993. Tree invasion and establishment in old fields at Hutcheson Memorial Forest. Bot Rev 59(4):251-72.

Nadian H, Smith SE, Alston AM, Murray RS. 1997. Effects of soil compaction on plant growth, phosphorus uptake and morphological characteristics of vesicular-arbuscular mycorrhizal colonization of Trifolium subterraneum. New Phytol 135(2):303-11.

Nagy R, Drissner D, Amrhein N, Jakobsen I, Bucher M. 2009. Mycorrhizal phosphate uptake pathway in tomato is phosphorus-repressible and transcriptionally regulated. New Phytol 181(4):950-9.

Negley TL and Eshleman KN. 2006. Comparison of stormflow responses of surface-mined and forested watersheds in the Appalachian Mountains, USA. Hydrol Process 20(16):3467-83.

Neumann G and Romheld V. 1999. Root excretion of carboxylic acids and protons in phosphorus-deficient plants. Plant Soil 211(1):121-30.

Noyd RK, Pfleger FL, Russelle MP. 1995. Interactions between native prairie grasses and indigenous arbuscular mycorrhizal fungi: Implications for reclamation of taconite iron ore tailing. New Phytol 129(4):651-60. 
Office of Surface Mining. 2008. OSM annual report: 2008. Washington, D.C.: U.S. Office of Surface Mining Reclamation and Enforcement, Department of the Interior.

Ohno T and Zibilske LM. 1991. Determination of low concentrations of phosphorus in soil extracts using malachite green. Soil Sci Soc Am J 55(3):892-5.

Paulitz TC and Linderman RG. 1991. Lack of antagonism between the biocontrol agent Gliocladium virens and vesicular arbuscular mycorrhizal fungi. New Phytol 117(2):303-8.

Plass WT. 2000. History of surface mining reclamation and associated legislation. In: Reclamation of drastically disturbed lands. Barnhisel RI, Darmondy RG,Daniels WL, editors. 2nd ed. Madison, Wisc: American Society of Agronomy. 1-20.

Plass WT. 1982. The impact of surface mining on the commercial forests of the United States. In: Post-mining productivity with trees. Kolar CA and Ashby WC, editors. Carbondale, III: Southern Illinois University Press. 1-7.

Pozo MJ and Azcón-Aguilar C. 2007. Unraveling mycorrhiza-induced resistance. Curr Opin Plant Biol 10(4):393-8.

Püschel D, Rydlová J, Vosátka M. 2008. Does the sequence of plant dominants affect mycorrhiza development in simulated succession on spoil banks? Plant and Soil 302(1):273-82.

Rawls WJ, Pachepsky YA, Ritchie JC, Sobecki TM, Bloodworth H. 2003. Effect of soil organic carbon on soil water retention. Geoderma 116(1-2):61-76.

Roberts JA, Daniels WL, Burger JA, Bell JC. 1988. Early stages of mine soil genesis as affected by topsoiling and organic amendments. Soil Sci Soc Am J 52(3):730-8.

Roemer W. 2006. New findings on phosphate uptake in plants - a literature survey. Archives of Agronomy and Soil Science 52(1):1-17.

Schlesinger WH. 1991. Biogeochemistry: An analysis of global change. San Diego, CA: Academic Press.

Schroeder PD, Radcliffe DE, Cabrera ML, Belew CD. 2004. Relationship between soil test phosphorus and phosphorus in runoff: Effects of soil series variability. J Environ Qual 33(4):1452-63.

Schussler A, Schwarzott D, Walker C. 2001. A new fungal phylum, the Glomeromycota: Phylogeny and evolution. Mycol Res 105:1413-21.

Scullion J, Mohammed ARA, Richardson H. 1988. Effect of storage and reinstatement procedures on earthworm populations in soils affected by opencast coal mining. J Appl Ecol 25(1):233-40.

Shannon CE and Weaver W. 1949. The mathematical theory of communication. Urbana: University of Illinois Press. 
Simmons JA, Currie WS, Eshleman KN, Kuers K, Monteleone S, Negley TL, Pohlad BR, Thomas CL. 2008. Forest to reclaimed mine land use change leads to altered ecosystem structure and function. Ecol Appl 18(1):104-18.

Skousen J, Ziemkiewicz P, Venable C. 2006. Tree recruitment and growth on 20-year-old, unreclaimed surface mined lands in West Virginia. International Journal of Mining, Reclamation and Environment 20(2):142-54.

Skousen J, Gorman J, Pena-Yewtukhiw E, King J, Stewart J, Emerson P, DeLong C. 2009. Hardwood tree survival in heavy ground cover on reclaimed land in West Virginia: Mowing and ripping effects. J Environ Qual 38(4):1400-9.

Smith SE and Read DJ. 2008. Mycorrhizal symbiosis. 3rd ed. Waltham, MA: Academic Press.

Smith E, Naik D, Cumming JR. 2011. Genotypic variation in aluminum resistance, cellular aluminum fractions, callose and pectin formation and organic acid accumulation in roots of populus hybrids. Environ Exp Bot 72(2):182-93.

Smith SE and Smith FA. 2011. Roles of arbuscular mycorrhizas in plant nutrition and growth: New paradigms from cellular to ecosystem scales. Annual Review of Plant Biology 62:22750.

Stahl PD, Williams SE, Christensen M. 1988. Efficacy of native vesicular-arbuscular mycorrhizal fungi after severe soil disturbance. New Phytol 110(3):347-54.

Steffen W, Crutzen PJ, McNeill JR. 2007. The anthropocene: Are humans now overwhelming the great forces of nature? AMBIO: A Journal of the Human Environment 36(8):614-21.

Stinson KA, Campbell SA, Powell JR, Wolfe BE, Callaway RM, Thelen GC, Hallett SG, Prati D, Klironomos JN. 2006. Invasive plant suppresses the growth of native tree seedlings by disrupting belowground mutualisms. Plos Biology 4(5):727-31.

Suding KN, Gross KL, Houseman GR. 2004. Alternative states and positive feedbacks in restoration ecology. TRENDS Ecol Evol 19(1):46-53.

Tabatabai MA and Bremner JM. 1969. Use of $p$-nitrophenyl phosphate for assay of soil phosphatase activity. Soil Biol Biochem 1(4):301-7.

Tarafdar JC and Jungk A. 1987. Phosphatase-activity in the rhizosphere and its relation to the depletion of soil organic phosphorus. Biol Fertility Soils 3(4):199-204.

Taussky H and Shorr E. 1953. A microcolorimetric method for the determination of inorganic phosphorus. Jour Biol Chem 202(2):675-85.

Torbert JL, Burger JA, Schoenholtz SH, Kreh RE. 2000. Growth of three pine species after eleven years on reclaimed minesoils in Virginia. Northern Journal of Applied Forestry 17(3):95-9. 
Townsend PA, Helmers DP, Kingdon CC, McNeil BE, de Beurs KM, Eshleman KN. 2009. Changes in the extent of surface mining and reclamation in the Central Appalachians detected using a 1976-2006 Landsat time series. Remote Sens Environ 113(1):62-72.

U.S. Energy Information Administration. 2010. Annual energy review 2009. Washington, D.C.: U.S. Department of Energy. Report nr DOE/EIA-0384(2009).

van der Heijden MGA, Klironomos JN, Ursic M, Moutoglis P, Streitwolf-Engel R, Boller T, Wiemken A, Sanders IR. 1998. Mycorrhizal fungal diversity determines plant biodiversity, ecosystem variability and productivity. Nature 396(6706):69-72.

Vance CP, Uhde-Stone C, Allan DL. 2003. Phosphorus acquisition and use: Critical adaptations by plants for securing a nonrenewable resource. New Phytol 157(3):423-47.

Vitousek PM, Mooney HA, Lubchenco J, Melillo JM. 1997. Human domination of Earth's ecosystems. Science 277(5325):494-9.

Watts WA. 1979. Late quaternary vegetation of Central Appalachia and the New Jersey coastal plain. Ecol Monogr 49(4):427-69.

Whipps JM. 2004. Prospects and limitations for mycorrhizas in biocontrol of root pathogens. Can J Bot -Rev can Bot 82(8):1198-227.

Wilson GWT, Hetrick BAD, Kitt DG. 1988. Suppression of mycorrhizal growth response of big bluestem by non-sterile soil. Mycologia 80(3):338-43.

Yano K, Yamauchi A, lijima M, Kono Y. 1998. Arbuscular mycorrhizal formation in undisturbed soil counteracts compacted soil stress for pigeon pea. Applied Soil Ecology 10(1-2):95-102.

Zak JC. 1992. Response of soil fungal communities to disturbance. In: The fungal community. Carroll GC and Wicklow DT, editors. New York, New York: Marcel Decker. 403-25.

Zhang Q, Yang R, Tang J, Yang H, Hu S, Chen X. 2010. Positive feedback between mycorrhizal fungi and plants influences plant invasion success and resistance to invasion. Plos One 5(8):e12380.

Zipper CE, Burger JA, McGrath JM, Rodrigue JA, Holtzman GI. 2011. Forest restoration potentials of coal-mined lands in the eastern United States. J Environ Qual 40(5):1567-77. 